Juliana Aragão Lemes da Costa

$O$ ensino de modelagem do vestuário: uma discussão sobre a criação de recursos pedagógicos

\begin{abstract}
Dissertação de Mestrado apresentada ao Programa de Pós-Graduação em Educação - Modalidade Profissional da Universidade de Brasília, como requisito parcial para obtenção do grau de Mestre em Educação, sob a orientação da Prof ${ }^{a}$. Dra. Olgamir Francisco de Carvalho
\end{abstract}


Ficha catalográfica elaborada automaticamente, com os dados fornecidos pelo(a) autor(a)

AJ94e Aragão Lemes da Costa, Juliana
O ensino de modelagem do vestuário: uma discussão
sobre a criação de recursos pedagógicos / Juliana
Aragão Lemes da Costa; orientador Olgamir Francisco
de Carvalho. -- Brasília, 2016.
82 p.
Dissertação (Mestrado - Mestrado em Educação) --
Universidade de Brasília, 2016.
1. Ensino de modelagem. 2. Material didático. 3.
Recurso pedagógico. I. Francisco de Carvalho,
Olgamir, orient. II. Título.


Juliana Aragão Lemes da Costa

\section{O ensino de modelagem do vestuário: uma discussão sobre a criação de recursos pedagógicos}

Dissertação de Mestrado apresentada ao Programa de Pós-Graduação em Educação - Modalidade Profissional da Universidade de Brasília, como requisito parcial para obtenção do grau de Mestre em Educação pela Comissão Julgadora composta pelos membros:

Comissão Julgadora:

Prof $^{\mathrm{a}}$. Dr ${ }^{\mathrm{a}}$. Olgamir Francisco de Carvalho (FE/UnB)

Prof. Dr. Bernardo Kipnis (FE/UnB)

Prof. Dr. Antônio Rodrigues da Silva Filho (FAU/UnB)

Prof. Dr. Remi Castioni (FE/UnB)

Aprovada em 29 de fevereiro de 2016 


\title{
Resumo
}

Este trabalho é resultado das inquietações surgidas durante a prática docente em modelagem plana do vestuário no Instituto Federal de Brasília. Constatou-se que os materiais didáticos tradicionais disponíveis não atendem plenamente às complexidades da realidade do trabalho e do processo de ensino-aprendizagem de modelagem. Seu objetivo é de desenvolver um recurso pedagógico que dê suporte a um ensino que leve em consideração a subjetividade presente em sala de aula e a própria complexidade dos processos de aprendizagem. A partir do aprofundamento das teorias de aprendizagem, do trabalho real e da experiência docente, desenvolveu-se um recurso pedagógico piloto que foi testado por meio da realização de pesquisa qualitativa na modalidade workshop. Após análise do material produzido - filmagens, produtos e questionário - concluiu-se que o recurso contribuiu para a aprendizagem de modelagem nas esferas cognitivas, motivacionais e interativas, e que seu alcance depende da prática pedagógica adotada. Após modificações resultantes deste processo, o recurso pedagógico é apresentado em forma de produto técnico, com indicações e sugestões de sua aplicabilidade.

Palavras-chave: Ensino de Modelagem. Material didático. Recurso pedagógico.

\begin{abstract}
This work is originated from the unease that grew during the practice of pattern making teaching in Brasilia Federal Institute of Education, Science and Technology (Instituto Federal de Brasília - IFB). It was found that the traditional teaching materials available do not respond adequately to the complexities of the profession and to the complexities of the learning processes. Our objective is to develop a learning material that takes in account the subjectivity present in our classrooms and that embraces the complexity of the learning processes itself. After considering contemporary learning theories, the profession and the experience acquired as a teacher, an educational material was developed. This prototype was tested during a two-day workshop. After analyzing the material collected - footage, products and survey - we concluded that it had a positive contribution for pattern making learning in all cognitive, incentive and interaction dimensions. Furthermore, its scope also depends on the pedagogical stand adopted. After some fine adjustments the educational material is presented in its final form with indications and suggestions for its use.
\end{abstract}

Keywords: Pattern-Making Teaching. Educational material. Pedagogical resources. 


\section{Lista de figuras}

$\begin{array}{ll}\text { Figura } 1 \text { - Etapas de Produção do Vestuário. } & 14\end{array}$

Figura 2 - Etapas de produção da modelagem industrial.

Figura 3 - Exemplo de esquema de bases do busto frente e costas. 15

Figura 4 - Processo de transformação de um molde-base em modelo recortado. 16

Figura 5 - Os processos fundamentais da aprendizagem. 22

Figura 6 - As três dimensões da aprendizagem. 22

Figura 7 - Exemplo de peça do mostruário tridimensional. 41

Figura 8 - Fluxo de procedimentos da aplicação de workshop de modelagem. $\quad 42$

Figura 9 - Desenho esquemático do produto técnico. 64

Figura 10 - Conjunto de modelagem, peça piloto e peça confeccionada. 66

Figura 11 - Subgrupos de classificação dos modelos em meia escala. 67

Figura 12 - Classificação alternativa de Subgrupos dos modelos em meia escala. $\quad 68$

\section{Lista de Gráficos}

Gráfico 1 - Distribuição de respostas à questão 1 do questionário. 48

Gráfico 2 - Distribuição de respostas à questão 2 do questionário. 48

Gráfico 3 - Distribuição de respostas à questão 3 do questionário. 49

Gráfico 4 - Distribuição de respostas à questão 4 do questionário. 50

Gráfico 5 - Distribuição de respostas à questão 5 do questionário. 50

Gráfico 6 - Distribuição de respostas à questão 6 do questionário.

Gráfico 7 - Distribuição de respostas à questão 7 do questionário. 52

Gráfico 8 - Distribuição de respostas à questão 8 do questionário. 53

Gráfico 9 - Distribuição de respostas à questão 9 do questionário. 53 


\section{Sumário}

INTRODUÇÃO

Origem do estudo $\quad 8$

Contextualização 9

Justificativa 10

Questão central da pesquisa $\quad 11$

Objetivo geral 11

Objetivos específicos $\quad 11$

Plano da dissertação 12

\section{CAPÍTULO 1 - REVISÃO TEÓRICA 13}

1.1 O trabalho de modelagem do vestuário 13

1.1.1 Etapas da produção do vestuário 13

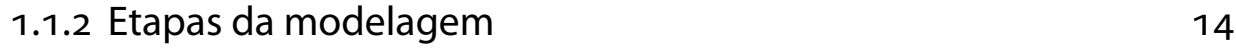

1.1.3 Uma visão abrangente sobre o trabalho de modelagem $\quad 17$

1.1.4 Trabalho prescrito e trabalho real $\quad 18$

1.2 A aprendizagem 20

1.2.1 Os processos básicos e as três dimensões da aprendizagem 21 Interação 23

Conteúdo 23

Incentivo 23

1.2.2 Os 4 Tipos de aprendizagem $\quad 24$

1.2.3 Obstáculos à aprendizagem 28

1.3 Concepções de ensino e suas consequências para a aprendizagem 29

1.3.1 O ensino tradicional de modelagem 29

1.3.2 O ensino não tradicional $\quad 32$

1.3.3 Recomendações para o ensino de modelagem 34

Considerações $\quad 35$

CAPÍTULO 2 - RELATO DA PESQUISA REALIZADA 37

2.1 O contexto de aprendizagem do IFB Taguatinga 37

2.1.1 A profissão de técnico em vestuário 38

2.1.2 Projeto de curso 38

2.1.3 Componente de Modelagem 39

2.2 Descrição da pesquisa realizada 41

2.2.1 Recurso pedagógico piloto $\quad 41$

2.2.2 Workshop 42

2.3 Análise dos dados e discussão dos resultados 44

2.3.1 Análise do Workshop $\quad 45$

Primeiro dia $\quad 45$

Segundo dia $\quad 45$ 
2.3.2 Análise das Modelagens

2.3.3 Análise do Questionário $\quad 47$

Considerações $\quad 55$

CAPÍTULO $_{3}$ - PRODUTO TÉCNICO 58

3.1 Apresentação do produto técnico 60

Objetivo 60

Quanto às dimensões da aprendizagem 61

Quanto aos tipos de aprendizagem 62

Resistências e defesas 62

Autonomia 63

Diversidade existente em aula 63

3.2 Descrição do produto técnico 64

3.3 Organização do recurso pedagógico 66

3.4 Aplicação e utilização do mostruário tridimensional 69

$\begin{array}{ll}\text { Considerações finais } & 70\end{array}$

$\begin{array}{ll}\text { REFERÊNCIAS } & 73\end{array}$

APÊNDICE A - Questionário do workshop de modelagem 75

APÊNDICE B - Tabela de classificação dos modelos 77

APÊNDICE C - Gráficos de frequência de ocorrência de peças 79

ANEXO A - Matriz curricular do curso técnico em vestuário- IFB 82 


\section{Introdução}

\section{Origem do estudo}

Esta pesquisa parte de inquietações surgidas na prática docente no ensino de modelagem do vestuário, componente integrante do curso profissionalizante de nível médio Técnico em Vestuário, no Instituto Federal de Brasília. A disciplina ministrada no semestre inicial do curso visa habilitar o aluno para a construção básica de moldes industriais femininos - desenhos geométricos riscados sobre o papel que traduzem as formas corporais tridimensionais. Vincula-se à disciplina de costura no semestre seguinte, já que os moldes produzidos serão utilizados como base para a prática de costura, e os alunos terão a oportunidade de acompanhar a passagem do molde - desenho feito em papel - para a vestimenta em tecido.

Os alunos que frequentam o curso, em sua maioria, têm escolaridade de nível médio e faixa etária entre 20 e 50 anos; enquanto uma minoria nunca trabalhou ou teve contato com a área de vestuário, grande parte possui experiência em confecções ou como profissional autônomo. Nestes casos, o aprendizado de modelagem e costura geralmente se dá em ambientes domésticos por meio de pessoas próximas e com a utilização de esquemas de moldes prontos - sistemas simplificados de cópias, como revistas e apostilas ${ }^{1}$ voltadas para o ambiente caseiro. Desta forma, muitos carregam para dentro de sala de aula atalhos prontos e soluções improvisadas nascidas e cultivadas no próprio fazer.

A prática de modelagem requer aquisição de conteúdos teóricos, destreza manual e outras habilidades fundamentais que precisam ser despertadas, como relacionar o desenho bidimensional ao corpo tridimensional e pensar nos processos subsequentes da cadeia de produção do vestuário. Espera-se também que o aluno desenvolva, no decorrer da disciplina, noções de geometria, ergonomia, matemática básica e habilidades com instrumentos de desenho técnico. $O$ aprendizado desta prática exige a mobilização das capacidades cognitivas, motoras e subjetivas - o cerne do problema deste projeto.

A vivência em ateliê é testemunha da recorrente dificuldade enfrentada pelos alunos em relacionar os instrumentos e desenhos produzidos no papel (modelagem plana)

\footnotetext{
${ }^{1}$ Podemos citar como exemplo de revistas: Revista Manequim e Revista Moda Moldes. As apostilas utilizadas mais comuns são: Método loli, Método Centesimal e Método Vogue.
} 
com a roupa ainda a ser confeccionada. Ou seja, aquilo que deveria estar acessível no campo concreto, encontra-se ausente, ainda no campo da abstração. Supõe-se que essas dificuldades tem como principais causas a falta de repertório de vestuário (tipos de peças, detalhamentos, execução e acabamentos); a falta de visualização tridimensional; e a disseminação de materiais didáticos inadequados para se enfrentar os desafios da prática de modelagem. Outra questão mais ampla, com a qual nos deparamos, diz respeito à própria concepção limitada que se tem sobre a profissão e o papel do modelista na resolução de problemas dentro de um contexto de produção.

Neste contexto, a comunicação em ateliê tem um alcance limitado, já que os alunos têm dificuldade em visualizar as reais consequências de suas operações realizadas no molde. Como o produto final ainda não existe, a compreensão das instruções, explicações e exemplos fica dependente de uma imaginação tridimensional ainda em desenvolvimento. Como não há um material didático para se fazer esta conexão entre o molde e a roupa vestida, recorre-se à imagens, gestos e desenhos improvisados para tentar se fazer entender.

\section{Contextualização}

A modelagem faz parte de um processo maior de produção do vestuário. A profissão tem como origem o ofício tradicional de alfaiataria, que detinha então todo o conhecimento da área e atuava em todas as etapas de fabricação da vestimenta, da concepção do modelo à sua modelagem, corte e costura. A formação profissional dos alfaiates no Brasil Colônia ocorreu de forma semelhante à das Corporações de Ofícios europeias, cujos profissionais eram divididas em três estágios: mestre, oficial e aprendiz. No entanto, as particularidades brasileiras (KENNER, 2005, p.27) como clima, antropometria, cultura, necessidades, materiais e mão de obra acabaram por modificar o trabalho ao longo do tempo.

O rápido processo de industrialização ocorrido no Brasil, a partir da década de sessenta, gerou uma grande pressão sobre a qualificação da mão de obra voltada à produção do vestuário. Como o país não dispunha de um sistema educacional abrangente o suficiente para suprir esta demanda, a qualificação profissional do setor da confecção do vestuário deu-se por uma pluralidade de meios à parte das instituições de ensino. Dezenas de publicações, cursos e apostilas multiplicaram-se e disseminaram-se como principal meio de aprendizagem de confecção do vestuário. Esses métodos eram fundamentados em sis- 
temas de cópias, repetição, e memorização, fornecendo fórmulas montadas, réguas para contornos de pontos, passo-a-passo, ampliação e redução de modelos, etc.

O acesso doméstico à modelagem foi em parte disseminado por essas revistas de fácil acesso e baixo custo, cujo método geralmente é baseado na aplicação de fórmulas e atalhos simples. Como a ênfase nestes meios sempre esteve voltada para o produto - e não para o processo - os praticantes são induzidos a utilizar atalhos prontos diante da necessidade de ajustes na peça.

Com a migração de costureiras domésticas para atuar no setor industrial sem uma adequada qualificação (KENNER, 2005), houve uma disseminação dessas práticas caseiras na área. Esses métodos caseiros atravessaram gerações e ainda persistem no mercado. $\mathrm{O}$ trabalhador não especializado acaba atuando na indústria, onde aplica seus conhecimentos domésticos. Deste modo, é evidente que cultivar-se-á dentro da própria indústria vícios e ciclos ineficazes de produção, e como consequência uma sub-valorização do trabalhador.

Um exemplo de uma prática doméstica que ocorre dentro da indústria é o da costureira - que está no final da cadeia produtiva têxtil - intervir na modelagem do produto final. Ao invés de um profissional capacitado para desenvolver um molde de qualidade, que atravesse todas as etapas de reprodução da roupa sem precisar de nenhuma alteração, recorre-se a uma prática improvisada realizada por um profissional não especializado. Com isso, gera-se um atraso na produção e obtém-se um produto comprometido, pois as intervenções no produto são feitos de modo intuitivo e baseados, em sua maioria, na experiência do trabalho caseiro ou em métodos prontos. Embora estes improvisos e atalhos sejam bastante úteis e difundidos em um ambiente caseiro, não seria adequado transpor estas práticas para outro contexto sem a devida reflexão.

\section{Justificativa}

O ensino tradicional de modelagem não coloca o aluno no centro do processo de aprendizagem, consequentemente, seus métodos e materiais didáticos não preveem necessidades oriundas de contextos e situações específicas em sala de aula. Considerar o aluno como principal sujeito da aprendizagem requer um novo olhar sobre as práticas de ensino de modelagem plana. Estas práticas devem ser revistas a partir das necessidades e da realidade do educando, não apenas por uma necessidade pragmática imediata, mas pelas consequências mais abrangentes que esta ação tem nos sujeitos. Trata-se, no fim das 
contas, de disponibilizar as ferramentas e os instrumentos para que o indivíduo possa enfrentar os desafios cotidianos de maneira autônoma, reflexiva e crítica.

\section{Questão central da pesquisa}

Pretende-se pesquisar quais as principais dificuldades enfrentadas pelo aluno durante o processo de aprendizagem de modelagem plana. Espera-se investigar em quais esferas (cognitiva, emocional ou relacional) essas dificuldades estão situadas. Almeja-se também, a partir da análise do material coletado, verificar como essas dimensões estão interligadas e como o processo de aprendizagem acontece para que se possa aperfeiçoar um material didático a ser utilizado nas aulas de modelagem plana.

A hipótese deste trabalho é que a distância entre o produto a ser desenvolvido (a roupa) e o desenho geométrico sobre o qual o aluno trabalha (a modelagem) causa uma interferência em todo o processo de aprendizagem, não só no campo cognitivo mas também nos campos emocional e relacional. Acredita-se que um recurso pedagógico adequado tem o potencial não só de aproximar teoria e prática, mas também de melhorar a comunicação, o ambiente de ensino e a própria motivação dos alunos em ateliê.

\section{Objetivo geral}

Investigar e analisar as consequências da inserção de um recurso pedagógico no ensino de modelagem plana. Espera-se aperfeiçoar este recurso para enriquecer o ambiente de ensino, facilitando os processos de cognição do sujeito e criando condições para uma aprendizagem mais significativa e duradoura.

\section{Objetivos específicos}

1. Descrever o trabalho real de modelagem;

2. Investigar como a aprendizagem acontece;

3. Definir diretrizes gerais para o ensino de modelagem e para a criação de um recurso pedagógico;

4. Aplicar pesquisa com produto técnico piloto e verificar as implicações da utilização deste recurso na aprendizagem de modelagem;

5. Aperfeiçoar produto técnico. 


\section{Plano da dissertação}

Este trabalho estrutura-se em três capítulos: o primeiro discorre sobre a fundamentação teórica, o segundo descreve a pesquisa realizada na modalidade de workshop e faz a análise dos dados e o último apresenta o produto técnico em sua versão final, com sua descrição e aplicação.

No primeiro capítulo apresentamos o trabalho de modelagem. São apresentados os conceitos de trabalho real e trabalho prescrito, de Pierre Trinquet (2010). Na sequência expomos a teoria de Knud Illeris (2003, 2007, 2013), utilizada como fundamentação teórica para se esclarecer os processos de aprendizagem. Será apresentado o conceito de aprendizagem, entendido aqui como todo processo de transformação duradoura do sujeito, resultante de processos internos e externos. Os diversos tipos de aprendizagem serão relacionados às esferas cognitiva, motivacional e de interação.

O segundo capítulo aborda a pesquisa aplicada, através da metodologia de pesquisa qualitativa. Foi realizado um workshop com alunos do Instituto Federal de Brasília com dois dias de duração. Nestes encontros foram produzidos três materiais para análise: vídeos, modelagens e questionários estruturados. Essa estrutura permitiu investigar algumas implicações da introdução de um recurso pedagógico na aprendizagem de modelagem. Observou-se a influência deste nos processos de construção do conhecimento, tanto no que se refere aos aspectos cognitivos, quanto aos emocionais e de interação.

O capítulo final é destinado à contextualização, justificativa e exposição do produto técnico - um recurso pedagógico - aperfeiçoado a partir da análise dos resultados da pesquisa realizada. É exposto não só o produto em si, mas também suas possibilidades de aplicação, alcance e limitações. O produto será apresentado não como objeto isolado, mas como uma ferramenta para o desenvolvimento de uma aprendizagem mais significativa e durável. Espera-se com isso favorecer a criação de um ambiente de aprendizagem mais aberto e plural, que estimule a autonomia do aprendiz, senso crítico e autogerenciamento da aprendizagem. Mais que uma proposição, espera-se que este produto seja um convite à reflexão. 


\section{Capítulo 1 - Revisão teórica}

Para que se possa desenvolver um recurso pedagógico voltado para o ensino de modelagem, é necessário percorrer um caminho que passe pelo aprofundamento sobre a natureza do próprio trabalho e quais conhecimentos, habilidades e competências são desejados. Também é fundamental compreender como a aprendizagem acontece em sua complexidade. Ao se confrontar as teorias contemporâneas de aprendizagem com o ensino tradicional de modelagem, veremos que este possui uma concepção de conhecimento inadequado para nosso contexto atual. A partir desta conclusão lançamos diretrizes para o ensino de modelagem coerentes com as expectativas contemporâneas sobre a prática profissional para, finalmente, definir as diretrizes para o desenvolvimento de um recurso pedagógico para o ensino profissionalizante.

\subsection{O trabalho de modelagem do vestuário}

A modelagem é a ponte entre a etapa de criação e a etapa de produção do vestuário. Sua função primordial é a de dar materialidade às concepções idealizadas pelo designer de moda, e seu fazer concentra-se em torno da transição entre o plano bidimensional do tecido e a superfície tridimensional do corpo. Este processo de dar forma às ideias depende de diálogos constantes com todo o setor produtivo. De um lado, pede uma comunicação direta com o designer para que a peça adquira caimento, acabamento e proporção desejadas - um trabalho minucioso que envolve ajustes, detalhamento e olhar crítico. Do outro, demanda conhecimentos técnicos para que a roupa percorra todas as etapas de produção - encaixe, corte e costura - de modo a garantir o máximo de qualidade, otimização dos materiais e mão de obra respeitando a concepção original do produto.

\subsubsection{Etapas da produção do vestuário}

O processo contemporâneo de feitura do vestuário industrial é estruturado em um sistema linear, no qual cada etapa é realizada por trabalhadores diferentes. A produção do vestuário pode ser dividida em duas fases: a de construção e a de reprodução do vestuário.

A Figura 1 ilustra de forma esquemática a produção do vestuário na indústria moderna. A fase de construção dá-se no setor de criação e de modelagem. O designer cria os modelos, define aviamentos, tecidos, estampas e tudo aquilo que diz respeito à estética. 
Após aprovação no setor, produz-se uma ficha com o desenho técnico para que o modelista planeje a execução com precisão. A partir desta produz-se um protótipo - primeira versão da roupa - para que o modelista e designer possam fazer suas considerações técnicas. Após aprovação a peça parte para a fase de reprodução.

ETAPAS DA PRODUÇÃO DO VESTUÁRIO

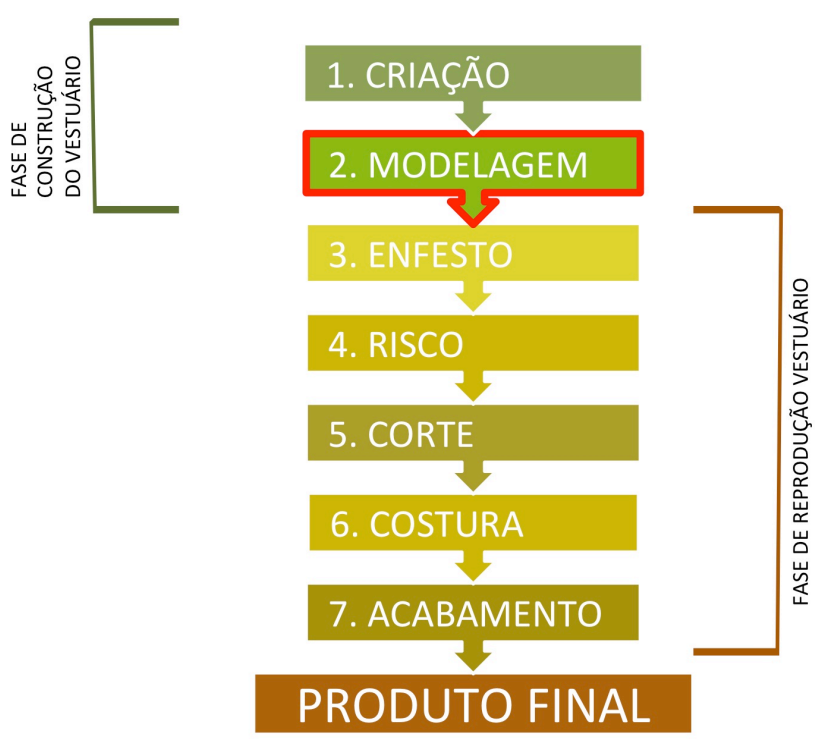

Figura 1 - Etapas de Produção do Vestuário. Fonte: autora

Nesta segunda fase, o trabalho do modelista passa a ser o de acompanhar a produção para eventuais ajustes na peça em questão ou em futuras modelagens . O molde é então preparado para corte em escala industrial. Na etapa de enfesto, o tecido é disposto em diversas camadas. Realiza-se então, o encaixe das modelagens, observando-se a direção dos fios do tecido, de acordo com as especificações fornecidas pelo modelista. Após posicionados, os moldes são riscados na primeira camada de tecido e então cortados. Posteriormente as peças são separadas em lotes e enviadas para o setor de costura, onde serão unidas para formar a peça final. Por último, a roupa passa pela etapa de acabamento onde realiza-se o processo de inspeção e análise da qualidade da roupa.

\subsubsection{Etapas da modelagem}

O trabalho de modelagem, por sua vez, ainda pode ser subdivido em mais duas fases e diversas etapas (Figura 2). A fase de construção da modelagem tem como objetivo principal transformar as informações ainda imprecisas dos desenhos, descrições e especificações do designer em um protótipo definido. A fase final tem como intenção preparar o 
molde para a reprodução, o que requer complementação do molde e especificação de detalhes técnicos.

\section{ETAPAS DA MODELAGEM DO VESTUÁRIO INDUSTRIAL}

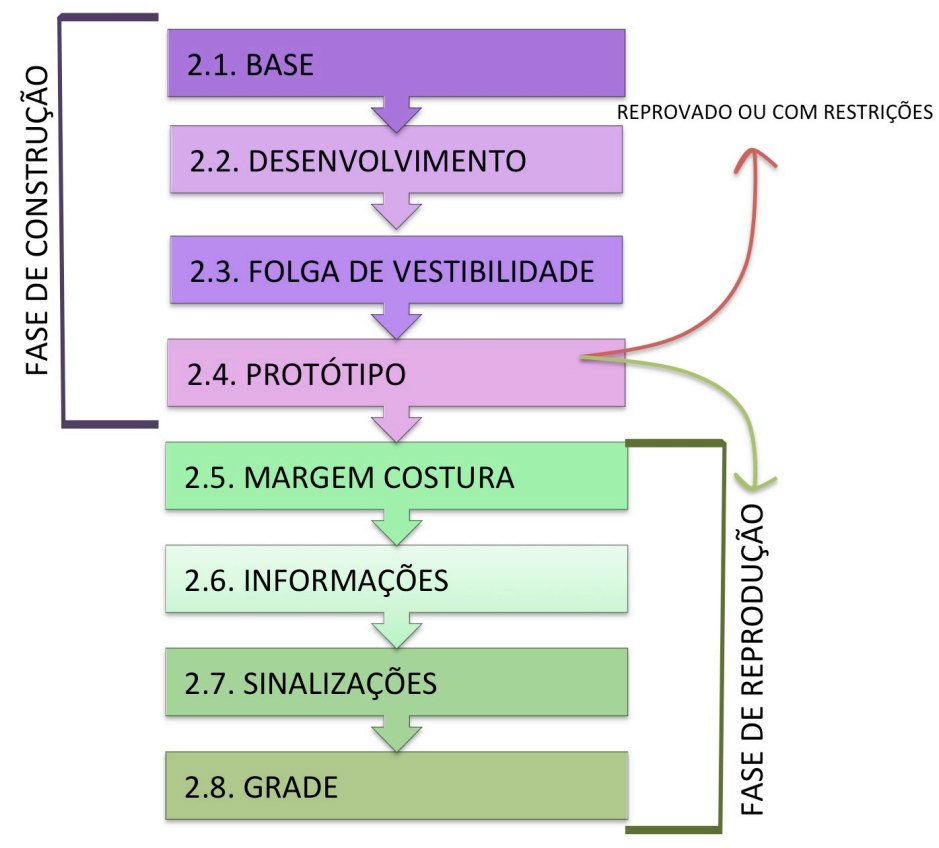

Figura 2 - Etapas de produção da modelagem industrial. Fonte: autora.

As duas principais técnicas para o início da modelagem são a plana e a tridimensional ou moulage. Na primeira, parte-se de um desenho básico enquanto que na segunda, o molde básico é extraído a partir da modelagem direta sobre o manequim ou corpo. A escolha vai depender do tipo de produto e a escala da confecção, mas, independentemente da técnica utilizada, a base do seu trabalho será sempre o molde bidimensional, seja ele padrão ou sob medida.

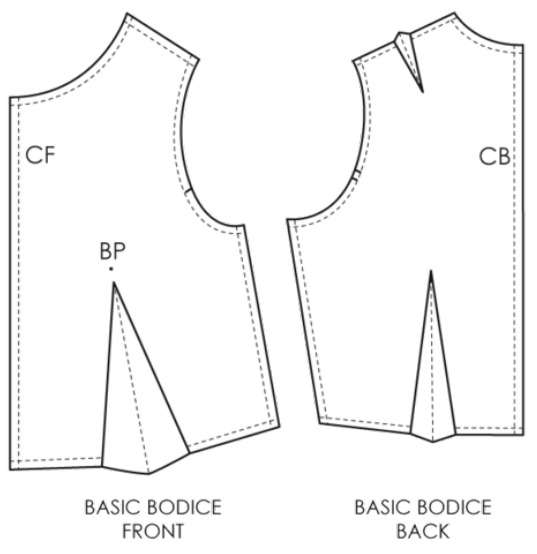

Figura 3 - Exemplo de esquema de bases do busto frente e costas. Fonte: <www.thecuttingclass.com>. Acesso em dez 2015. 
O profissional que trabalha na produção industrial geralmente utiliza a modelagem plana. Nestes casos o trabalho é iniciado a partir de moldes referências (Figura 3) que são diagramas geométricos com medidas padrão e já previamente confeccionados e testados. Após a definição de um grupo de moldes base (etapa 2.1), o modelista partirá para o desenvolvimento dos modelos (etapa 2.2). Para transformar as modelagens básicas no modelo desejado é necessário transpor as formas, proporções, caimento do tecido e acabamentos do vestuário idealizado para os moldes (ver Figura 4). Durante ou após esse processo, também é preciso planejar as folgas de vestibilidade (etapa 2.3), de acordo com a necessidade funcional da peça. As estruturas dos moldes-base são ajustadas ao corpo, por isso devem atender às expectativas ergonômicas, funcionais e estéticas.
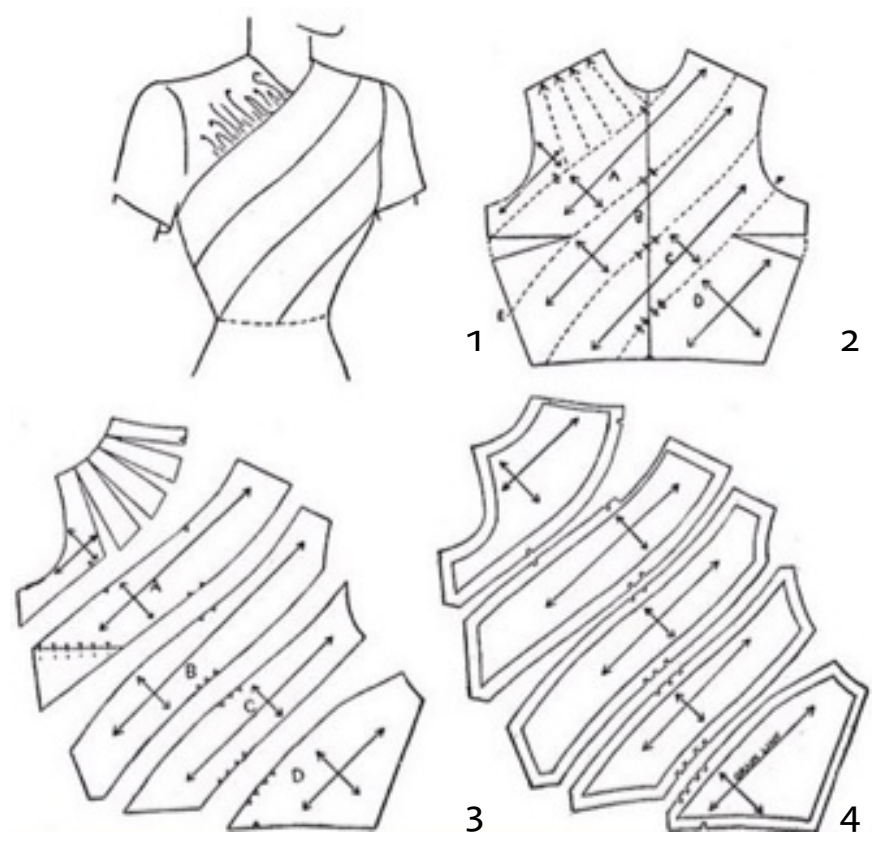

Figura 4 - Processo de transformação de um molde-base em modelo recortado com franzido no ombro a partir de um desenho de referência. 1) Desenho de referência; 2) Marcações e esquema de corte; 3)Separação; 4) Adição de margens de costura e sinalizações. Fonte: <https://vk.com/wall63144799? offset=360>. Acesso em: 15 dez. 2015.

Após a finalização da modelagem, confecciona-se um protótipo (etapa 2.4), geralmente em um tecido semelhante ao que será produzido em larga escala. Apenas as costuras principais são realizadas e dispensa-se os acabamentos e detalhes minuciosos, pois o objetivo é visualizar de maneira ampla a forma final, caimento, conforto e encaixe dos moldes. Essa análise é feita pelo estilista e modelista, e após aprovação, o modelista irá preparar os moldes para que sejam reproduzidos. Nesta segunda fase, são acrescentadas as margens de costura de acordo com o tipo de acabamento e maquinário utilizado (etapa 2.5). Completa-se os moldes com informações técnicas (etapa 2.6) e sinalizações (etapa 
2.7) a fim de esquematizar o corte, sentido dos fios para orientar o encaixe e destacar marcações para que se tenha mais precisão na costura. O processo se repete na gradação (etapa 2.8), que consiste em ampliar e reduzir os moldes para obter-se os tamanhos previstos. Finalmente os moldes seguem para a reprodução.

\subsubsection{Uma visão abrangente sobre o trabalho de modelagem}

O trabalho de modelagem é sem dúvida uma atividade técnica especializada, isto é, possui um conjunto de conhecimentos e práticas pertencentes ao próprio campo profissional. O fazer requer de seu profissional habilidades técnicas, rigor, organização, precisão no desenho e na manipulação dos instrumentos, repertório de costura, noções de matemática e geometria. Todavia, os conteúdos e habilidades técnicas são insuficientes para se descrever a atividade.

Devido à sua posição no processo produtivo, o trabalho de modelagem não está confinado a seu aspecto considerado 'técnico', ou seja, não é apenas um problema de desenho e especificação, mas uma atividade que deve considerar e responder às diversas demandas oriundas do processo produtivo como um todo. $O$ trabalho não se resume em simplesmente resolver o problema pontual apresentado, mas envolve também a capacidade de propor soluções satisfatórias a partir de um processo de negociação com todos os envolvidos no processo.

Como consequência, o trabalho também adquire uma qualidade generalista e sensível, já que todas as tomadas de decisão (e suas consequências) devem considerar o contexto único e complexo no qual o trabalho está sendo desenvolvido. Isto requer do profissional capacidades mais amplas, relativos ao desenvolvimento pessoal - as chamadas competências, que incluem as avaliações pessoais e atitudes subjetivas - e integram tudo que é necessário para a performance na diversidade de situações ou contextos da profissão. Além dos conhecimentos técnicos, este fazer exige visão global dos processos, exige também uma postura curiosa em relação a seu entorno, comunicação constante com as demais equipes de criação e de produção, envolvimento e capacidade de argumentação e de negociação.

Embora a técnica seja imprescindível para a prática profissional, esta não se resume à simples aplicação de um conhecimento fechado em si. Devido à complexidade e a imprevisibilidade, cada situação nova requer diferentes abordagens, espírito investigativo, capacidade de pesquisa, de reformulação de problemas, flexibilidade e criatividade. Essas 
habilidades não são desenvolvidas apenas pela assimilação de conteúdos técnicos, já que dependem de uma mobilização de forças e ações internas do sujeito. Neste contexto, não basta um aperfeiçoamento teórico na área profissional. Faz-se necessário um aperfeiçoamento global do sujeito, isto é, um desenvolvimento não só de aspectos cognitivos, mas também emocionais e motivacionais e de aplicação do conhecimento em situações imprevisíveis e desafiadoras.

\subsubsection{Trabalho prescrito e trabalho real}

Pierre Trinquet (2010) tem uma perspectiva bastante interessante sobre o trabalho, já que reconhece e traz à tona a divergência entre o que o trabalho deveria ser e o que ele é na prática. Quando estudamos, aprendemos e discutimos sobre uma atividade profissional, geralmente estamos nos referindo à atividade de maneira idealizada, sem considerar as dificuldades ou influências externas a ela. Toda e qualquer interferência, ineficiência, desentendimento, falta de comunicação, motivação ou indisposição durante a prática profissional é visto como inadequado ou inapropriado, e não merece ser considerado como parte inerente ao próprio fazer humano.

Trinquet considera o trabalho como sendo um ato próprio da natureza humana e portanto, portador e restituidor dessa mesma complexidade. O autor abarca essa dualidade e classifica o trabalho em dois tipos: o prescrito e o real. O primeiro é o objeto do trabaIho e tudo aquilo que precede à sua realização, enquanto o último é a ação de um sujeito em uma situação única no tempo e no espaço. Enquanto o trabalho prescrito é estático, linear, o trabalho real, por ser executado por um humano é vivo, passível de mudanças, pois sofre a interferência subjetiva.

O trabalho prescrito considera que uma determinada atividade será sempre desenvolvida em condições ideais de espaço, ritmo, temperatura, luminosidade e por um trabaIhador com um nível de concentração e motivação constantes.

O conhecimento relacionado ao trabalho prescrito é tudo aquilo transcrito em diversas formas, como materiais, livros, softwares, cursos, ferramentas, procedimentos. Todo este conhecimento anterior ao ato é imprescindível à realização do trabalho. Este conjunto de conhecimentos é chamado por Trinquet (2010) de Saber Constituído. Este saber formal é aquele que pode ser registrado, compartilhado e ensinado justamente por ser algo 'teóri-

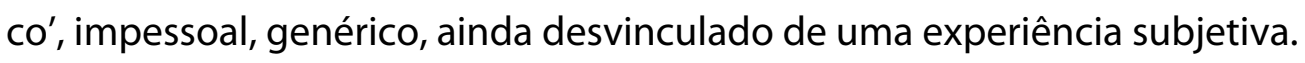


Já o trabalho real, por outro lado, considera que uma atividade será necessariamente desenvolvida em um ambiente não ideal, com distrações, por um trabalhador com nível variável de concentração e motivação, e com comportamentos e costumes particulares. $O$ trabalho real é a ação de um sujeito, com suas particularidades, história, memórias, ideologias, emoções e motivações em um determinado tempo e lugar, em condições únicas. "O trabalho a realizar jamais encontra o mesmo indivíduo, nem o mesmo coletivo, no tempo e no espaço [...] é preciso gerir e se adaptar às variabilidades do ambiente físico e do meio social [...]" (TRINQUET, 2010, p.98). Segundo o autor, é impossível descrever com exatidão a atividade real do trabalho, já que ele é influenciado por um sujeito único no tempo e espaço. A adaptação e a modificação são inerentes à própria vida e a rigorosa padronização e normatização da atividade humana são impossíveis .

Essa distância entre o trabalho prescrito e o trabalho real é preenchida por um tipo de saber específico: o Saber Investido. Este conhecimento é tudo aquilo que foi internalizado pelo sujeito na diversidade de situações vivenciadas e geralmente faz parte de sua memória, história e identidade. O Saber Investido é de difícil explicação, acesso e compartiIhamento, pois encontra-se profundamente arraigado no sujeito, no corpo e no modo de agir e de reagir a determinadas situações. Este saber é uma construção pessoal, íntima e segundo Trinquet "Trata-se de um saber que está em aderência com a atividade. Ele não é formalizado e nem escrito em qualquer lugar. Essa experiência está cravada no intelecto e/ou no corpo [...]" (2010, p.101). Este saber é que permite ao trabalhador reagir a situações imprevistas com bastante eficiência ou também tomar ações preventivas diante de conjunturas muito particulares e inacessíveis ao Saber Constituído.

Saber Investido e Saber Constituído possuem naturezas distintas, porém não excludentes. Geralmente é a partir do conhecimento formal que se tem acesso à experiência que possibilita a internalização de um conhecimento. E por outro lado, grande parte do conhecimento formal adquirido tem origem no registro dos saberes investidos de diversos mestres e artesãos: Modus operandi de diversos instrumentos, ferramentas e até normas as de desenho técnico, por exemplo - tem origem muitas vezes relacionados ao fazer. No ensino formal há uma tendência a se desconsiderar o saber investido como fonte legítima de saberes. Frequentemente, este saber investido não é sequer comentado, outras vezes fala-se dele de maneira muito distante. Provavelmente, a invisibilidade deste saber aos 
olhos da academia deve-se mais à impossibilidade desta em prever e abordar todas as inúmeras variáveis e imprevistos que acontecem no trabalho real.

A formação portanto, deveria colocar como questão central a atividade real do trabalho prático, e não somente a prescrita. Considerar a situação do trabalho real é fundamental para se manter a prática pedagógica ancorada nas reais necessidades de aprendizagem que o trabalho demanda. E embora a aula não seja o contexto real de trabaIho - com seu dinamismo, ambiente, pressão, imprevistos, responsabilidade e relações sociais - faz-se necessário criar situações que despertem essas habilidades necessárias em um contexto variável e que mantenha o aprendiz nesse estado de consciência ativa.

Embora não seja o objetivo do ensino formal de "ensinar" este saber investido do mesmo modo que a prática profissional o faz, acredita-se que há espaço para se aproximar os dois tipos de saberes ou ao menos preparar o aprendiz para a prática. Isto se daria por meio da criação de contextos educacionais no qual haja lugar para a imprevisibilidade e onde adaptação, flexibilidade e criatividade possam ser praticados. Também acredita-se que o trabalho de modelagem requer um ensino que não se limite apenas aos aspectos técnicos e objetivos, mas que leve em consideração a complexidade da prática como referência para a prática pedagógica. Para tanto, o ensino deve criar situações abertas que possibilitem em cada aprendiz o desenvolvimento de habilidades, competências e saberes relacionados à complexidade da prática profissional real.

\subsection{A aprendizagem}

Além de voltarmo-nos para o trabalho de modelagem, devemos também aprofundar o conhecimento sobre a aprendizagem em si. Compreender como esta acontece é fundamental para que se possa elaborar um recurso pedagógico aberto e de amplo alcance enquanto meio de desenvolvimento das habilidades e competências que o trabalho de modelagem exige.

Diversas visões e teorias de aprendizagem com diferentes perspectivas, bases epistemológicas e conteúdos foram desenvolvidas desde as últimas décadas do século XIX. Autores como Piaget, Vygotsky, David Kolb, David Ausubel, Karl Rogers, Yrjo Engestron, Jack Mezirow, Peter Jarvis, Howard Gardner, dentre outros, apresentaram teorias com significativas contribuições para o entendimento da aprendizagem. Em grande parte essas teorias aprofundam-se ora no processo externo de interação entre o indivíduo e seu ambi- 
ente social, cultural ou material, ora no processo psicológico interno de elaboração e aquisição de conhecimentos. Compreender a aprendizagem somente a partir do campo externo ou interno cobre parcialmente o assunto, pois ambos os campos são relevantes para a compreensão dela.

Acredita-se que devido à complexidade do próprio processo, faz-se necessária uma teoria ao mesmo tempo abrangente e não excludente, já que outros autores certamente possuem contribuições relevantes para o aprofundamento da questão. Neste contexto, optou-se por utilizar a teoria de aprendizagem de Knud Illeris (1999, 2007)², em função desta estabelecer uma síntese geral e atual do campo, além de abarcar uma ampla seleção das principais teorias existentes e as situar em um mesmo campo teórico.

\subsubsection{Os processos básicos e as três dimensões da aprendizagem}

Inicialmente Illeris define a aprendizagem como sendo "qualquer processo que, em organismos vivos, leve a uma mudança permanente em capacidades e que não se deva unicamente ao amadurecimento biológico ou ao envelhecimento" (2007, p.3).

A teoria parte do pressuposto que toda aprendizagem envolve a integração de dois processos distintos: um externo e outro interno. O externo acontece quando há interação entre o indivíduo e seu contexto social, cultural ou material. E o processo interno está relacionado às questões emocionais, motivacionais, psicológicas, e de elaboração e aquisição de conhecimentos (ILLERIS, 2013, p.17). Ou seja, em toda aprendizagem há um processo externo, de interação, e outro interno, de aquisição.

A aprendizagem inicia-se pela interação do indivíduo com o meio, e pode ter a forma de percepção, transmissão, atividade, experiência, imitação, participação etc. Esses impulsos são incorporados ao processo interno de elaboração e aquisição. A dimensão do incentivo é ativada simultaneamente, e proporciona a energia mental necessária para o processo de aprendizagem. Assim, os impulsos iniciais, após processados pelas emoções, ativam a dimensão cognitiva que consolidará a aprendizagem - que pode ser de vários tipos. Os tipos de aprendizagem que podem ocorrer dependem do contexto, da qualidade da interação, da situação do sujeito e de sua quantidade de energia mental disponível ou mobilizada para internalização da informação, conteúdo ou situação.

\footnotetext{
${ }^{2}$ Seu livro "As três dimensões da aprendizagem" foi inicialmente publicado em 1999, em dinamarquês. O autor revisou e ampliou sua teoria no livro intitulado "How We Learn - Leraning and non learning in school and beyond", publicado em 2007, em inglês.
} 


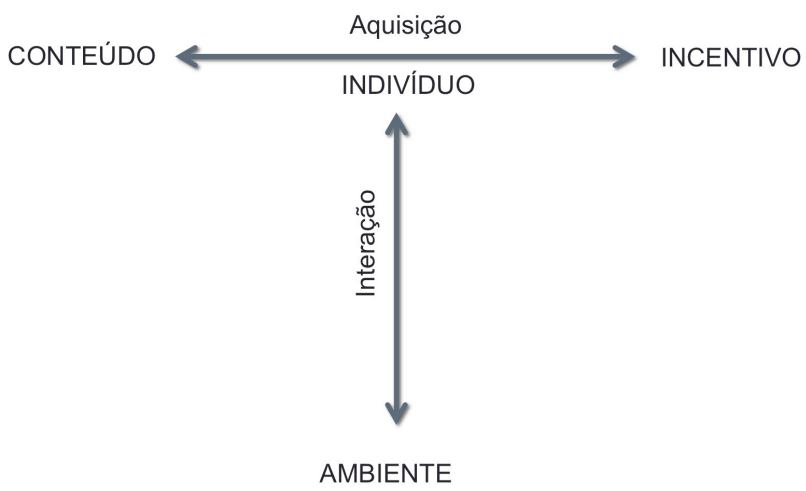

Figura 5 - Os processos fundamentais da aprendizagem. Fonte: Illeris, 2013.

A Figura 5 representa os processos fundamentais da aprendizagem, na parte inferior está o ambiente, a base geral da aprendizagem, e na superior está o indivíduo, o aprendiz específico. O processo externo de interação entre ambos é representado por uma dupla seta vertical. Já o processo interno de aquisição é representado por uma dupla seta horizontal, posicionada sobre o indivíduo, que possui em suas extremidades as dimensões do incentivo e do conteúdo. A simetria e ausência de hierarquia entre ambas deve-se ao fato que elas estão sempre interligadas em qualquer forma de aprendizagem.

Conectados os três polos, forma-se um triângulo que representa as três dimensões da aprendizagem (Figura 6), que sempre estão envolvidas quando ela ocorre. Ele representa o campo de tensão da aprendizagem e inclui o desenvolvimento da funcionalidade, sensibilidade e sociabilidade que, segundo o autor, são os componentes gerais das chamadas competências (ILLERIS, 2013, p.19).

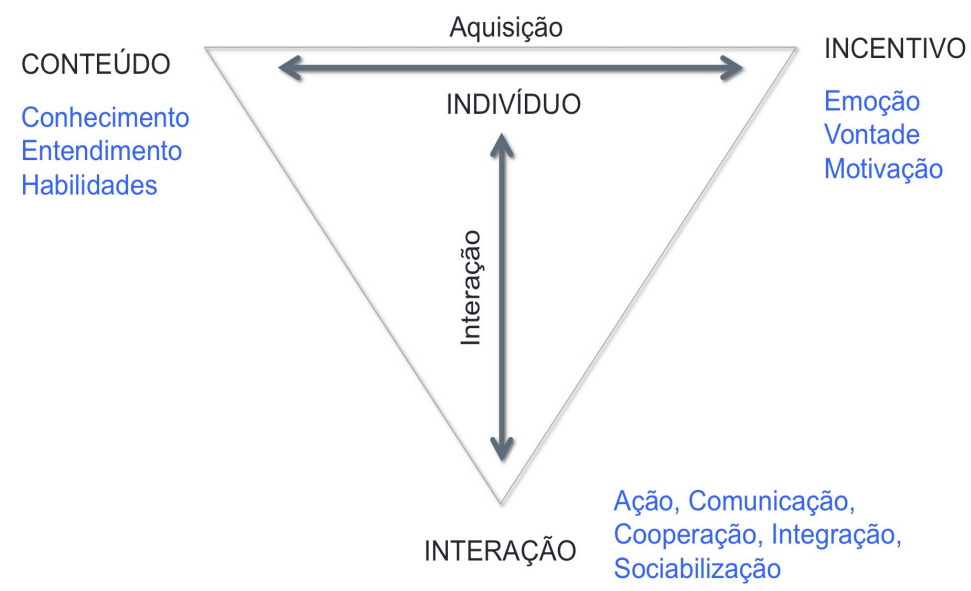

Figura 6 - As três dimensões da aprendizagem. Fonte: Illeris, 2013. 


\section{Interação}

A dimensão da interação fornece os impulsos que dão início ao processo de aprendizagem, e podem ocorrer na forma de percepção, transmissão, experiência, imitação, atividade e participação. Sua função é a de desenvolver a integração e a sociabilidade do indivíduo, porém depende das demais dimensões.

As dimensões do conteúdo e do incentivo dependem, crucialmente, do processo de interação, do meio social, material ou cultural. Podemos tomar como exemplo uma aula: se a interação for conflituosa, a aprendizagem pode não ocorrer ou pode haver distorções, ou ainda os estudantes podem absorver uma visão negativa do tema, do professor ou da situação escolar. Essa negatividade pode formar uma barreira à aprendizagem, tema que será abordado mais adiante.

\section{Conteúdo}

A dimensão do conteúdo diz respeito àquilo que é aprendido - aquilo que o aprendiz sabe, é capaz de fazer e compreender. Está ligada aos conhecimentos, habilidades, significados, posturas, valores, modos de agir, métodos, estratégias ou atitudes. O conteúdo também pode ser uma aquisição geral da cultura e dos contextos sociais dos quais fazemos parte, também chamados de formação. Seu papel é o de desenvolver a funcionalidade geral do indivíduo diante das necessidades de lidar com os desafios da vida prática. $O$ conteúdo prévio do sujeito é fundamental para que a aprendizagem ocorra, pois esta precisa se relacionar com as estruturas já consolidadas. Isto é extremamente relevante, pois a quantidade de energia e o esforço para se aprender algo novo está diretamente relacionada com as estruturas de conhecimento existentes no sujeito. Quanto mais adequadamente o sujeito estiver preparado para receber um determinado conteúdo, mais fácil será sua apreensão. Por outro lado, se as estruturas existentes no sujeito forem insuficientes, ou se o conhecimento estiver estruturado de uma forma conflitante com o que está sendo apresentado, maior será o empenho necessário para agregar esse novo conhecimento. Neste caso, a motivação e o equilíbrio emocional se tornam componentes fundamentais deste processo.

\section{Incentivo}

A dimensão do incentivo é responsável por disponibilizar e direcionar a energia mental necessária para o processo de aprendizagem e envolve sentimentos, emoções e 
motivação. Sua função é a de garantir o equilíbrio emocional do indivíduo e a de desenvolver uma sensibilidade pessoal. Quando se fala em aprendizagem, o foco geralmente está na aquisição do conteúdo, porém a dimensão do incentivo é parte indissociável deste processo. Para que ele aconteça, é necessário vontade interna e certa disposição para a mudança. Assim, a dimensão do incentivo pode ser crucial para impulsionar a aprendizagem e a tornar mais duradoura. Por exemplo, ao se ensinar dois alunos a construírem diagramas geométricos de modelagem do vestuário, se constata que ambos, mesmo estando engajados de maneira distinta, aparentemente sabem o mesmo conteúdo. No entanto, a longo prazo, o aluno que se sentiu mais confiante e motivado provavelmente terá construído uma relação diferente com o conteúdo que o aluno que teve uma relação negativa em sala de aula ou se sentiu desmotivado. Aquele que aprendeu e se sentiu confiante, possivelmente terá uma relação positiva e será mais fácil para ele recordar o conteúdo. Da mesma forma, ele estará mais disposto e inclinado a aplicar seus conhecimentos em diversos contextos. Já o aluno desmotivado terá uma probabilidade maior ao esquecimento do conteúdo, já que sua relação negativa ou de indiferença em relação ao assunto tornará mais difícil o acesso à informação em questão. A tendência, nestes casos, é a de evitar situações em que tenha que utilizar esses conteúdos, tanto pela questão afetiva ou emocional, quanto pela quantidade de energia interna necessária. A durabilidade e o valor da aprendizagem resultante estão intimamente relacionados com a dimensão do incentivo.

Interação, conteúdo e incentivo estão sempre em jogo quando a aprendizagem acontece. Se desejarmos tratar da aprendizagem em sua complexidade, não podemos tratar dessas três dimensões de maneira isolada. Em qualquer situação de aprendizagem a interação e o próprio conteúdo sempre ativarão uma resposta psicológica do campo do incentivo, seja ela positiva ou negativa. No entanto, apesar de estarem sempre conectadas e de um campo afetar ou outro, não se pode afirmar que haja um determinismo no processo. Em uma interação conflituosa, por exemplo, não se pode dizer que a aprendizagem não irá ocorrer. Todavia, podemos afirmar que nesta situação provavelmente será necessário um maior dispêndio de energia para que ela ocorra como foi planejada, ou que ela não ocorrerá da mesma forma que foi idealizada.

\subsubsection{Os 4 Tipos de aprendizagem}

Imaginemos uma situação típica em uma sala de aula, onde um conteúdo é apresentado e posto em prática com os alunos. Ao final do dia os alunos, que aparentemente 
vivenciaram a mesma experiência, aprendem coisas distintas. Alguns aprendem mais do que foi inicialmente planejado enquanto outros não conseguem assimilar nem parte do que foi apresentado. Um grupo se sente motivado e consideram o conteúdo 'fácil' enquanto outro sente o oposto. Uns ficam nitidamente empolgados enquanto uns poucos mostram indiferença. Às vezes um bom aluno aprende algo com naturalidade e até certa apatia, enquanto aquele com maior dificuldade fica comovido com o pouco que acabou de aprender. Ou então pode acontecer de um aluno não se envolver o suficiente, por achar o assunto fácil demais, e terminar não aprendendo nada. Pode também acontecer de um aluno se mostrar inicialmente hostil e desafiador em relação ao proposto, mas ao final do dia revelar-se cordial e agradecido. Como explicar todas estas situações com uma teoria sobre a aprendizagem?

Na verdade, não podemos afirmar que a experiência foi a mesma para todos os alunos, já que a interação não foi igual. O professor não responde da mesma maneira para um aluno desafiador, indiferente, interessado ou afetuoso. A relação afetiva e o modo como o conteúdo se conectou com o que o aluno já sabe ocorreram de modos diversos e singulares com cada um desses indivíduos, portanto, a aprendizagem também acontece de maneiras distintas.

Segundo Illeris (2007), para que se tenha uma compreensão mais ampla do conteúdo apresentado, é necessário considerar que existem diversos tipos de aprendizagem. Estes tipos estão classificados de acordo com o modo com que o conteúdo se relaciona à estrutura singular existente no sujeito. Eles dependem do tipo de interação, de conteúdo e da afetividade em jogo. Cada tipo de aprendizagem exige do indivíduo uma quantidade de energia a ser investida para absorver determinado conteúdo. Essa disposição dependerá da estrutura prévia do sujeito, sua motivação interna, da qualidade da interação e do conteúdo apresentado. Os quatro tipos de aprendizagem são a cumulativa, assimilativa, acomodativa e significativa (ILLERIS, 2007). Estas podem ocorrer ocasionalmente ou simultaneamente e diferem de pessoa para pessoa.

A aprendizagem mecânica ou cumulativa é caracterizada por uma informação nova que é assimilada de maneira isolada que não faz parte de nenhum esquema ou padrão preexistente. Ela é feita de maneira automática, como a memorização isolada de uma senha ou número. Sua aplicação e profundidade são bastante limitadas, pois somente tem utilidade em situações muito específicas. 
A aprendizagem assimilativa ou por adição é a que ocorre com maior frequência e acontece quando novas informações são acrescentadas ou acopladas a um esquema já existente. É relativamente fácil recordar e acessar essas novas informações, principalmente estando no contexto onde se desenvolve gradualmente uma capacidade de se fazer adições constantes.

A aprendizagem acomodativa é aquela que requer uma desconstrução de um esquema preexistente para que a nova informação pode ser assimilada. É um processo muito mais desgastante pois envolve fazer um movimento contra algo que já estava estabelecido internamente. Sua ocorrência depende de grande mobilização de forças internas para resolver esse conflito que surge. Como resultado, é obtido um real domínio e uma compreensão aprofundada sobre aquilo que se aprendeu. O processo de aprendizagem pode se manifestar como uma crise, onde o aprendiz luta por um tempo com um problema que é importante e urgente para si. Seu alcance e duração são bastante amplos devido ao grande esforço e investimento para assimilar esta nova informação.

Por fim, a aprendizagem significativa ou transformadora é a mais profunda e ampla, e acontece geralmente em momentos de crise ou de grande transformação pessoal. Ela caracteriza-se por uma desconstrução de grupos de esquemas e padrões em todas as três dimensões da aprendizagem, podendo provocar mudanças na personalidade. Exige um grande gasto energético e volição, e seu alcance é bastante duradouro e significativo.

Há um progressivo aumento na quantidade de energia necessária para que os diferentes tipos de aprendizagem aconteçam. Também há um aumento no alcance e na duração de cada tipo. Os tipos cumulativo e assimilativo ocorrem com maior frequência, enquanto o acomodativo ocorre em ciclos maiores. Já a aprendizagem transformadora acontece apenas poucas vezes em nossas vidas. No entanto, isto não quer dizer que uma é necessariamente melhor que a outra. Embora, a princípio, a aprendizagem cumulativa não seja muito estimada em um ambiente educacional, também não é necessário que cada nova aprendizagem seja sempre acomodativa ou transformadora, pois não é sempre que temos a necessidade e a disponibilidade de energia interna para nos reestruturar.

A aprendizagem pode acontecer de maneira associativa para uns e de maneira acomodativa ou transformadora para outros. Algumas coisas não requerem praticamente nenhum esforço para serem aprendidas e não necessitam de grandes mobilizações inter- 
nas, já outras podem entrar em conflito com as estruturas existentes no sujeito e devido à sua importância, demandam grandes reestruturações internas.

Tomemos um outro exemplo em sala de aula, no qual o aluno levanta uma dúvida sobre qual régua curva utilizar para o desenho de um molde. A explicação do professor sobre os princípios gerais utilizados na escolha do tipo de régua e sua relação com o corpo humano pode requerer do aluno uma sensibilidade e uma disposição para compreender as formas do corpo com seus movimentos e combinações de curvas e ângulos. $\mathrm{O}$ aluno pode aceitar esta explicação como sendo natural, e a aprendizagem aqui provavelmente é a associativa. Ou então, se o aluno estiver acostumado à respostas simples, por exemplo, a aceitação desta exposição irá implicar em uma revisão de seu modo de aquisição de informações. Esta mudança pode confrontar todos ou parte dos conteúdos adquiridos no passado, já que esses últimos aparentemente foram aceitos sem real compreensão. Da mesma maneira, as aprendizagens futuras serão impactadas por esta alteração no modo como ele processa as informações recebidas. Elas irão exigir maior envolvimento e entendimento para serem aceitas, pois as respostas simples não serão mais suficientes. Essa transformação pode gerar uma grande incerteza e hesitação sobre a aceitação ou não do que está sendo apresentado. No caso da aceitação, pode ocorrer uma aprendizagem acomodativa ou até uma transformadora, a depender da abrangência da reestruturação interna do sujeito, mesmo se tratando de um conteúdo relativamente simples. Por outro lado, se não tiver disposição para este movimento interno, o aluno pode não aceitar a explicação do professor e exigir uma resposta objetiva e direta. Neste caso a aprendizagem também pode ocorrer de forma cumulativa, basta que o aluno memorize o tipo de régua a ser utilizada para cada parte do corpo - uma decisão bem menos dispendiosa em termos de mobilização interna que a anterior. Em todos os três casos a aprendizagem aconteceu, no entanto variaram em alcance e, certamente, em durabilidade.

O processo de aquisição pode ocorrer de modos distintos para cada indivíduo - a depender dos conteúdos já adquiridos, da maneira como este conhecimento está organizado e da energia interna disponível para viabilizar esta assimilação. Neste processo, o educando deixa transparecer o tipo de aprendizagem que está em curso por meio de suas reações, sejam elas positivas ou negativas. Ou seja, a depender do modo como o aluno responde, reage ou se defende da explicação do professor, é possível vislumbrar o potencial de cada situação de aprendizagem. 


\subsubsection{Obstáculos à aprendizagem}

Quando a aprendizagem pretendida não ocorre ou ocorre de maneira incompleta ou distorcida, considera-se que houve uma falha no processo. Isto acontece com maior frequência de que o desejado, portanto, é necessário um aprofundamento dessa questão da não aprendizagem para que se possa lidar com a situação na prática. A compreensão sobre esses entraves permite que, quando detectadas durante o processo, se direcione os esforços para o acontecimento de uma aprendizagem acomodativa ou transformadora. Tais ocorrências podem estar relacionadas a qualquer uma das três dimensões da aprendizagem e frequentemente estão associadas a mais de uma ao mesmo tempo.

Segundo Illeris (2007, p.157), os obstáculos à aprendizagem podem ter origem em processos internos - como problemas de autoestima, falta de motivação, questões psicológicas e cognitivas - ou em processos externos - como uma relação desgastada ou conflituosa em sala de aula ou mesmo na instituição. Os de origem interna são chamados de mecanismos de defesa, que existem previamente à interação de aprendizagem e estão internalizadas no indivíduo. Os de origem externa são denominados resistência mental, e são uma resposta à própria situação de aprendizagem.

Os mecanismos de defesa são essenciais para lidarmos com o constante fluxo de informações a que estamos expostos no cotidiano. Sem ele teríamos dificuldade para filtrar e selecionar aquilo que é relevante, interessante e significativo para nós. Com ele nos protegemos de informações inconsistentes com nossa visão de mundo, crenças e ideologias. No entanto, estes mecanismos também podem ser um obstáculo desnecessário e é preciso investigar a origem da defesa para que se possa atuar para sua superação. A ambivalência (ILLERIS, 2007, p.167) é um exemplo desses mecanismos em ação, no qual o sujeito quer absorver o conhecimento, mas sabe que isso exigirá um nível muito alto de energia a ser despendida para desconstruir aquilo que já conhece. Com isso, encontra-se dividido entre essas forças opostas de querer e não querer se engajar em adquirir um novo saber. Nestes casos, um incentivo pode ser a diferença entre aprender e não aprender.

A resistência mental, por outro lado, é ativada pela interação, geralmente em situações na qual se vivencia uma grande tensão, quando algo não é aceitável ou na presença de um conflito no processo de aquisição de um conteúdo. Nos ambientes escolares, a resistência geralmente é vista como um empecilho, um problema ou um desvio de conduta. Entretanto, quando compreendida sua natureza e superada, normalmente produz uma 
aprendizagem de grande significado. As aprendizagens derivadas dessas resistências são predominantemente acomodativas.

Os obstáculos à aprendizagem sempre existirão de uma forma ou de outra em qualquer ambiente de ensino. Compreender as origens e os tipos de barreiras é fundamental para que o facilitador possa elaborar estratégias e abordagens mais adequadas à situação. Em termos pedagógicos, trata-se de um desafio criar um espaço para a aprendizagem aberto o suficiente para que esses obstáculos possam se revelar de maneira natural como legítimas formas de expressão do educando. Caso contrário, esses obstáculos à aprendizagem poderão permanecer ocultos e essa frustração pode se reverter em defesas e bloqueios. Como consequência, permanecerão presentes durante todo o processo dificultando e tornando menos eficiente a aprendizagem. Portanto, cabe ao contexto escolar possibilitar a manifestação dessa resistência e de transformá-la de maneira construtiva.

\subsection{Concepções de ensino e suas consequências para a aprendizagem}

Um ensino voltado verdadeiramente para a prática profissional deve compreender tanto a profissão quanto o processo de aprendizagem em suas complexidades para somente então estabelecer seus objetivos, conteúdos, metodologias, matérias didáticos e práticas pedagógicas. Ao se confrontar o ensino tradicional com as teorias aqui apresentada, podemos verificar que o método tradicional mostra-se inadequado para a formação profissional aqui desejada. A partir de então iremos desenhar as características desejadas para um ensino de modelagem coerente com as concepções apresentadas.

\subsubsection{O ensino tradicional de modelagem}

O modelo de ensino tradicional se concentra principalmente na aprendizagem assimilativa, ou seja, na adição de novos conteúdos em esquemas já existentes. O ambiente educacional é organizado em função de conteúdos que devem ser ministrados considerando as estruturas supostamente já assimiladas. Geralmente, este modelo considera a dimensão do conteúdo (conhecimentos, habilidade, competências) como a mais importante, enquanto a dimensão de incentivo (motivação, emoção e volição) e a da interação (ação, comunicação, cooperação) de modo periférico.

Antes de lançar a proposta de um recurso pedagógico para o ensino de modelagem plana do vestuário, é importante discutir o ensino tradicional de modelagem plana do vestuário. De acordo com Maria Isabel da Cunha (1998, p.10) o ensino tradicional pos- 
sui certas características que de um modo geral desconsideram o sujeito no processo de aprendizagem.

Primeiramente o conteúdo é visto de maneira isolada e acredita-se que ele é pronto, acabado. Ele é apresentado de maneira descontextualizada, sem ser situado como processo histórico. O resultado final é o que importa, enquanto que os processos de construção do conhecimento são periféricos.

Nesta perspectiva, os professores buscam situações de ensino controladas e previsíveis, com foco no pensamento convergente. Buscam a reprodução fidedigna do conteúdo. Ser competente é transferir com precisão e segurança um determinado conteúdo. Por meio de uma postura geralmente autoritária, buscam ter sempre as respostas prontas para os problemas. Ou seja, a interação ocorre no sentido vertical em mão única, onde o professor tem o domínio absoluto sobre a informação e as situações de aprendizagem. O novo normalmente é rejeitado e os erros e bloqueios não são vistos como etapas da aprendizagem.

Os alunos, nesse contexto, são colocados em uma condição de passividade. Eles buscam a resposta única e verdadeira, não há espaço para a criatividade já que essa supõe a divergência, a dúvida e a possibilidade de múltiplos caminhos e soluções (CUNHA, M. I., 1998, p.11). Eles não são estimulados pela perspectiva de que a produção de conhecimentos é fruto de inquietações, contradições, desejos e sentimentos. Por desconsiderar a subjetividade, as resistências de aprendizagem são vistas como um desvio, uma conduta inapropriada, uma perturbação na aula. A atividade de pesquisa é supervalorizada e reservada, não se leva em consideração que o homem é por natureza capaz de investigar, simplesmente porque pensa, tem dúvidas e vive (CUNHA, M. I., 1998, p.2).

No ensino de modelagem é bastante comum a utilização de um conjunto de recursos, práticas e materiais didáticos que tem origem em uma concepção de conhecimento tradicional. O conteúdo em modelagem geralmente é visto de maneira descontextualizada e por vezes o professor adota um método que não considera o contexto histórico no qual foi produzido.

Por vezes há um grande apego por parte do professor ao método de executar a modelagem, evitando explorar outros materiais. Como consequência, o aluno se torna refém daquela maneira única de fazer e o aprendiz se conforma com essa visão que se ajusta àquele ensino de mão única. $\mathrm{A}$ aprendizagem parece acontecer somente com a presença 
do professor e com o auxílio de materiais didáticos que possuem fórmulas prontas, ou réguas com formatos específicos.

Os exercícios visam uma situação controlada e com recorrência utilizam-se apostilas com passo-a-passo. Assim o aluno constrói a modelagem e obtém um resultado já esperado, percorrendo esse caminho com o mínimo de dúvidas e perturbações. Se esta abordagem aparentemente diminui as perturbações em sala, por outro lado não favorece que o aluno crie, altere ou questione aquilo que está sendo feito, apenas que cumpra o roteiro.

Quando se está desenvolvendo um modelo, perde-se a habilidade de visualização da proporção humana, já que esta fica em segundo plano. Resta aos alunos uma tabela numérica com valores descontextualizados que devem ser memorizados e utilizados segundo uma regra nem sempre muito clara. Esta abordagem desconectada das referências corporais também é utilizada no ensino dos instrumentos de trabalho, como as réguas francesas e de alfaiate. Com isso perde-se a oportunidade de associar a ferramenta com a sensibilização do olhar para as formas do corpo humano. Como consequência não são desenvolvidas as habilidades de se pensar em aspectos ergonômicos e estéticos, e a própria análise e correção das modelagens - prática cotidiana do profissional - fica prejudicada.

O manequim técnico é utilizado como recurso recorrente para a construção de modelagens e provas de roupas. No entanto, enquanto o manequim é um corpo estático, padronizado e simétrico, o corpo humano é vivo e assimétrico. Enquanto o modelista industrial trabalha com medidas padronizadas, as modelistas de pequenas empresas ou autônomas trabalham em corpos com medidas exclusivas. Em ambos os casos, a roupa vestirá um corpo real. Mesmo no caso industrial, a roupa será experimentada em uma modelo de prova para um parecer técnico. Quando o ensino não incorpora esta interação com corpos reais, não se desenvolve competências importantes que fazem parte do trabalho real, como reconhecer e solucionar questões de conforto, usabilidade, movimento, rugas, deformações, caimento e proporção, e transpor essas alterações para o molde.

É comum a elaboração das aulas por agrupamento dos modelos de acordo com o grau de complexidade. Todos executam modelos iguais, inicialmente os mais básicos e depois os mais avançados. Os alunos que desejarem executar algo mais avançado por conta própria acabam sendo reprimidos, já que existe um receio por parte dos docentes em perder o controle da situação. Em razão disto, todos são obrigados a fazer os mesmos mo- 
delos de acordo com o prescrito. Com isso, perde-se a oportunidade de estimular que o aluno gerencie sua aprendizagem e conheça seus limites.

Esta concepção tradicional do ensino utiliza-se de um conjunto de práticas e recursos cujo resultado não atende plenamente às exigências e expectativas de formação de um profissional na contemporaneidade. Esta exige, a capacidade de trabalhar em um contexto cada vez mais dinâmico e de crescente complexidade.

\subsubsection{O ensino não tradicional}

Ao se analisar os recursos pedagógicos tradicionais para o ensino de modelagem verifica-se que estes não favorecem a criação de um ambiente de aprendizagem mais aberto e rico. Por não levarem em consideração a pluralidade de aptidões, habilidades, competências e inclinações do alunos em conduzir o próprio processo, cria-se uma situação na qual todos são compelidos a seguir um mesmo passo a passo, e a obter o mesmo resultado.

Esta ruptura com as formas tradicionais de entender o conhecimento enquanto objeto fechado e acabado é necessária se desejarmos uma mudança de rumo no ensino de modelagem. Para que um novo ensino e novos materiais possam ser desenvolvidos, devemos compreender que a concepção que se tem do conhecimento antecede sua prática pedagógica adotada. Cunha, em seu livro "O professor universitário na transição de paradigmas", expõe as características desta nova proposta (1998, p.13). O conhecimento é tido como provisório, relativo e em contínua construção. Estimula-se a análise, argumentação, construção de ideias e raciocínios para a resolução dos problemas. A curiosidade, o questionamento, a dúvida e o erro são partes fundamentais do processo de aprendizagem. As habilidades sócio-intelectuais são tão valorizadas quanto os conteúdos. Neste cenário, o aluno é colocado no centro do processo, já que é ele quem aprende.

Esta visão mais crítica do conhecimento apresenta-se também no merca-
do de trabalho, onde buscam-se profissionais que possam alterar/ir além
daquilo que já existe, que ousem criticar, que tenham compreendido co-
mo se constrói uma vestimenta para que possam alterá-la, não somente
como reproduzi-las, profissionais que compreendam o porquê de cada
item do que é descrito num diagrama, para que, caso quei-
ram/necessitem, possam desenvolver sua própria forma de moldá-los
(BEDUSCHI, 2013, p.115)

Além de uma mudança de paradigma, os recursos pedagógicos utilizados nas aulas de modelagem devem favorecer as percepções que são despertadas no próprio fazer. Atu- 
almente, a utilização de livros com passo-a-passo coloca o aprendiz numa situação controlada e passiva, dependente de instruções, já que o aluno consome aquele conhecimento e o entende como ponto de chegada. No entanto, em uma situação real não haverá um roteiro pronto para os inúmeros desafios que irão exigir tomadas de decisão, senso crítico, risco e vontade de investigação para solucioná-los.

Os materiais didáticos impressos, como livros e apostilas, são sistemas fechados, com início, meio e fim - e tem tendência a estimular um pensamento linear. [...] O aluno se limita a aprender as técnicas por repetição e se habitua a repetir mecanicamente as instruções dos diagramas, sem refletir sobre sua formação, continuidade ou mesmo conexão entre os conteúdos (BEDUSCHI, 2013, p.115).

Em sua pesquisa sobre materiais didáticos da área de modelagem plana feminina, Beduschi (2013) conseguiu identificar que a falta da visualização tridimensional nos moldes feitos no papel gerava uma compreensão parcial por parte do aluno. Ela defende a meIhoria dessa capacidade cognitiva através do uso da técnica de modelagem tridimensional em conjunto com a técnica de modelagem plana, em movimentos pausados para alternar entre uma e outra. Ainda, a autora sugere a utilização de roteiros com passo-a-passo e a repetição de modelos para guiar as práticas.

Acredita-se que esta abordagem possa trazer reais benefícios para a visualização tridimensional, como Beduschi (2013) constata em sua pesquisa. No entanto, a mobilização de energia necessária para aprender dois métodos concomitantemente é consideravelmente maior e a utilização de roteiros faz com que o processo adquira um caráter linear e se concentre em etapas pré-estabelecidas para que se chegue ao produto final, possibilitando poucas modificações por parte dos alunos. Ainda, a adoção de métodos passo-apasso tende a desconsiderar a diversidade dos tipos de aprendizagem. A técnica tridimensional, sendo escultórica e na qual se antevê a forma final, certamente contribui para o problema da visualização tridimensional. No entanto, ela não resolve o problema de visualização da roupa finalizada, com os tipos de acabamentos e costura, pois o trabalho ainda encontra-se em um estágio inicial do processo.

É preciso colocar em prática uma estrutura que favoreça a expressão e a produção de conhecimentos novos (TRINQUET, 2010, p.108). Assim, o aluno deve se tornar protagonista do seu trabalho e de seu próprio ensino, e isso pode ser facilitado por meio da modificação da metodologia de ensino e dos recursos pedagógicos. 


\subsubsection{Recomendações para o ensino de modelagem}

Deve-se proporcionar um ensino onde o aluno possa tomar decisões e observar suas consequências. Estimular que ele gerencie o seu processo e faça suas escolhas, mesmo que por razões subjetivas. Que ele possa estabelecer as prioridades, formar parâmetros, e aplicar as exigências técnicas na ordem interna que ele julgar mais interessante. E em caso de erro, este deve ser valorizado enquanto tentativa de tomar as rédeas de sua própria educação.

As atividades e exercícios deverão ser abertos, ou seja, no qual o aprendiz está em um estado ativo buscando resolver os problemas encontrados, mobilizando e colocando em ação suas capacidades. Eles devem privilegiar a investigação, a tentativa e erro, discussões e ramificações de assuntos de interesse do próprio estudante. Em outras palavras, a prática em atelier deve ser viva e orgânica, não linear e estática. No processo de desenvolvimento da modelagem deve-se estimular as transformações e intervenções por parte do aprendiz. Se o aprendiz quer desenvolver algo mais complexo e desafiador, porque impedi-lo?

Quanto ao currículo, na maioria dos cursos superiores e técnicos a disciplina de costura e de modelagem são separadas. A separação em si, não é prejudicial, afinal cada uma tem seu assunto. Entretanto, se forem trabalhadas em conjunto, podem se beneficiar mutuamente de uma aproximação entre estes dois assuntos que na prática, estão intimamente ligados. A disciplina de modelagem deve ao menos confeccionar um protótipo de cada molde, para que o aluno visualize tridimensionalmente a roupa. A disciplina de costura deve executar roupas inteiras, com todas as partes de moldes, para se aprender a sequência de montagem. É importante que as disciplinas tenham um planejamento do conteúdo e métodos, para que haja coerência no processo e para que uma dê suporte à outra.

Deve-se incorporar a prática da prototipagem na disciplina de modelagem para que os moldes se tornem vestuário. Assim é possível perceber sua forma final, seus encaixes, vestibilidade, proporções, caimento e seja realizada uma análise das percepções físicas que emana do próprio material. Também é desejável que essa primeira confecção aconteça sob a supervisão do docente que ministra a disciplina de modelagem, assim o processo de prova, análise e correção dos moldes torna-se mais rápido e eficaz.

Outra recomendação é de utilizar corpos reais para a construção e análise da modelagem, já que considerar essa diversidade no contexto de ensino modifica a interação e a 
maneira como se elabora o produto de modelagem. Cria-se um ambiente desafiador, enriquecendo a prática de modelagem. Ao criar-se uma situação de risco e dúvida, a capacidade do olhar crítico será realmente requisitada e colocada em ação. Além de se estimular a busca de soluções através da tentativa e erro, haverá um aumento do repertório por meio da variedade de experimentos individuais compartilhados.

Por fim, é necessário um ensino que coloque o aprendiz em evidência, que seja reconhecido seu processo de aquisição de conhecimento e que trabalhe para que este tenha significado para próprio aluno.

\section{Considerações}

Se levarmos em consideração as teorias sobre o trabalho real (e não apenas o trabaIho prescrito), os processos básicos da aprendizagem, as dimensões da interação, do conteúdo e do incentivo, os quatro tipos de aprendizagem e os mecanismos de defesa inerentes ao processo, concluiremos que o ensino de modelagem em sua forma tradicional não responde de maneira adequada às demandas de um contexto profissional cada vez mais complexo e sujeito a mudanças.

Considerando o modo como a aprendizagem acontece, é desejável que o ensino preocupe-se não só com os conteúdos, mas também com a qualidade da interação e a diversidade existente em uma sala de aula. A subjetividade de cada estudante pede uma diversidade de respostas, atitudes e ações do professor. A flexibilidade e abertura para o enfrentamento de novos desafios são essenciais para se navegar por este contexto. Ao se aceitar que as resistências, barreiras e atritos são inerentes ao próprio processo de aprendizagem, o ensino não os rechaça, mas trabalha de maneira consciente sobre estas situações para que possam ser superadas e a aprendizagem possa acontecer.

Não se trata de subestimar os conteúdos, mas de reconhecer que estes conhecimentos são provisórios e incompletos. Consequentemente, dá-se mais valor ao processo de aquisição, pois a simples verbalização ou escrita não atesta o modo como esta informação foi internalizada nem seu significado para o sujeito.

Um ensino que leve em consideração o trabalho real deve preocupar-se em preparar os aprendizes para enfrentar este cenário aberto e repleto de desafios nunca enfrentados em um contexto educacional. Além de uma base sólida em conhecimentos técnicos, deve-se estimular o pensamento reflexivo, a autonomia, o processo de tomada de deci- 
sões, a pesquisa, a resolução de problemas complexos e a abertura necessária para a reformulação dos problemas apresentados. Além disso, deve-se estimular que o educando tome consciência dos processos envolvidos em sua própria aprendizagem, para que ele possa aprender a aprender. É importante ressaltar que não se trata de treiná-lo da mesma forma que se faz no ensino tradicional para estas situações, pois a própria concepção de ensino se torna mais aberta e flexível. Não basta um ajuste de conteúdo - embora este exista - mas faz-se necessária uma mudança de paradigma da própria concepção de ensino. 


\section{Capítulo 2 - Relato da pesquisa realizada}

Por esta pesquisa tratar do desenvolvimento de um recurso pedagógico, faz-se necessário apresentar o contexto em que estas inquietações iniciais surgiram para então tratarmos do estudo em si. Inicialmente, expomos a conjuntura do Instituto Federal de Brasília e do curso técnico em vestuário, com seu projeto, organização curricular e disciplinas, também chamadas de componentes. A seguir, discutimos o caso específico do que ocorre nas aulas de modelagem, com suas dificuldades e desafios. Completamos a parte inicial com a apresentação do produto piloto acompanhado de sua justificativa. Na segunda parte relatamos a pesquisa realizada e a metodologia empregada, assim como descrevemos detalhadamente os procedimentos e materiais utilizados no workshop de modelagem realizado em dois dias na instituição. Na terceira parte avaliamos o desempenho do recurso pedagógico a partir da experiência vivenciada e da análise do material produzido - vídeos, modelagens e respostas ao questionário. Concluímos com algumas reflexões sobre o recurso e com diretrizes para o aperfeiçoamento do material.

\subsection{O contexto de aprendizagem do IFB Taguatinga}

O Instituto Federal de Brasília (IFB) é uma instituição pública que oferece Educação Profissional gratuita, na forma de cursos e programas de formação inicial e continuada de trabalhadores (FIC), educação profissional técnica de nível médio e educação profissional tecnológica de graduação e de pós-graduação, articulados a projetos de pesquisa e extensão. O IFB foi criado em dezembro de 2008, por meio da lei n 11.892, passando a compor a Rede Federal de Educação Profissional, Científica e Tecnológica, existente em todo o Brasil. Atualmente, é composto por uma Reitoria e 10 campi distribuídos pelo Distrito Federal: Brasília, Ceilândia, Estrutural, Gama, Planaltina, Riacho Fundo, Samambaia, São Sebastião, Taguatinga e Taguatinga Centro. Sua estrutura multicampi permite à instituição distribuir os diversos eixos tecnológicos de acordo com a vocação econômica das regiões administrativas do Distrito Federal.

Atualmente o campus Taguatinga oferta cursos técnicos em vestuário (nível médio) e o curso superior em tecnologia Design de Moda. Esta oferta está vinculada à vocação da região, considerada a capital econômica do Distrito Federal, com importante centro co- 
mercial e polo de atração para a população das regiões próximas. Taguatinga também é considerada a cidade com maior índice de industrialização no setor da cadeia produtiva da indústria do vestuário no Distrito Federal (SINDIVESTE/2008 apud INSTITUTO FEDERAL DE BRASÍLIA, 2011, p.14), sendo mais relevantes as áreas de comércio, distribuição e indústria de confecções. Além disso, a região situa-se próximo ao Polo de Modas do Guará, resultado do Programa de Promoção de Desenvolvimento Econômico do Distrito Federal (PRODF). Espera-se que quando completo, o setor será responsável por impulsionar esta atividade econômica na região. Além disso, desde 2006 Brasília recebe eventos de moda em nível nacional ${ }^{3}$, o que vem incentivando a produção regional e coincidindo com a abertura de diversos cursos superiores na área de Design de Moda. Neste contexto, o curso técnico em vestuário tem grande relevância para a formação e qualificação dos profissionais que irão atuar neste mercado.

\subsubsection{A profissão de técnico em vestuário}

O técnico em vestuário tem uma atuação bastante abrangente, mas em geral podese afirmar que é o profissional que supervisiona o processo de confecção do indumento. Ele pode atuar em diversas funções e cargos em empresas, como assistente de produção, auxiliar de modelagem, planejamento, controle ou supervisor de produção, supervisor de qualidade ou como profissional autônomo e empreendedor em negócios de modelagem, risco e confecção. Por supervisionar processos e lidar com diversos segmentos da cadeia produtiva, é esperado deste profissional que se relacione bem com as pessoas, que aceite desafios, tenha iniciativa, liderança e disponha de bom senso, dinamismo e flexibilidade. Espera-se que também seja capaz de gerenciar equipes de trabalho, propor ideias inovadoras, ser criativo na resolução de problemas e buscar constantemente seu desenvolvimento profissional e pessoal.

\subsubsection{Projeto de curso}

De acordo com o proposta original, o Curso Técnico em Vestuário tem como objetivo formar profissionais empreendedores, capazes de desenvolver atividades e funções típicas da área, segundo os padrões de qualidade e produtividade requeridos pela natureza do trabalho técnico, respeitando-se as normas de segurança do trabalho e de preservação ambiental (INSTITUTO FEDERAL DE BRASÍLIA, 2011, p.16). Por essa razão sua formação

\footnotetext{
${ }^{3}$ São eles o Capital Fashion Week, o Brasília Fashion Festival e o Claro Park Fashion
} 
é bastante ampla e inclui aspectos de gestão administrativa, gerenciamento de produção, manutenção de máquinas, softwares de modelagem, encaixe e desenho técnico, administração dos processos produtivos, inovações tecnológicas, comunicação e expressão, ergonomia, normas e segurança do trabalho, além de modelagem, costura, desenho técnico e laboratórios de criação.

Ainda, segundo o documento, as políticas, programas e as práticas pedagógicas deverão criar condições favoráveis para que os egressos tenham um conjunto de competências básicas e profissionais que permitam desenvolver suas atribuições com segurança, além de serem capazes de lidar com contextos caracterizados por mudanças, competitividade, necessidade constante em aprender, rever suas posições e práticas, desenvolver e ativar valores e atitudes, analisar tendências de mercado, elaborar estratégias de negócios e de marketing adequadas a cada caso, utilizando conceitos administrativos, econômicos e comerciais (INSTITUTO FEDERAL DE BRASÍLIA, 2011, p.18).

O curso é organizado em três módulos de aprendizagem, um a cada semestre letivo, articulados e estruturados de acordo com os Referenciais Curriculares do MEC/SETEC pertencendo ao eixo Industrial. Cada um destes módulos contempla um conjunto de competências e habilidades mirando a construção do perfil do profissional. A distribuição das bases tecnológicas e dos componentes curriculares segue uma sequência lógica de construção de conhecimentos (INSTITUTO FEDERAL DE BRASÍLIA, 2011, p.22). O módulo básico visa preparar o aluno para as certificações intermediárias, nas quais estarão qualificados como auxiliar de costura, no segundo módulo e supervisor na confecção do vestuário, no terceiro módulo. Após completados todos os módulos e o estágio curricular supervisionado, o aluno fará jus ao diploma de habilitação Técnico em Vestuário.

\subsubsection{Componente de Modelagem}

A disciplina de modelagem integra o principal eixo do curso, o de produção do vestuário. Cerca de 60\% da carga horária total do curso está reservado para as componentes curriculares de desenho, modelagem, costura e laboratórios de criação.

Modelagem Feminina é a primeira de um conjunto de quatro componentes do grupo (feminina, masculina e infantil, tridimensional, computadorizada), ministrada no módulo inicial do curso e com carga horária de $90 \mathrm{~h} / \mathrm{a}$. Por ser a primeira a tratar do assunto, cabe a ela apresentar os princípios fundamentais de modelagem, já que nos demais componentes apenas alteram-se as questões antropométricas e ergonômicas. Articula-se 
também com os componentes de costura, ministradas nos demais módulos. Como consequência desta organização curricular, há uma lapso temporal entre as etapas de modelagem e de fechamento da peça.

De acordo com a ementa do componente, espera-se dos alunos que, ao final desta, sejam capazes de desenvolver moldes de peças de roupas femininas e que estejam habilitados a tirar as medidas do corpo humano, construir bases de modelagens, interpretar (ou desenvolver) modelos e elaborar a grades das peças. Para tanto, os aprendizes são introduzidos à modelagem plana feminina, estudam as relações entre o corpo humano e as medidas tabeladas, e desenvolvem um conjunto de exercícios práticos, acompanhados por aulas expositivas o orientações individuais no decorrer das atividades.

As turmas possuem até 36 alunos, em sua maioria mulheres, com escolaridade geralmente de nível médio e faixa etária entre 20 e 50 anos. Portanto, são bastante heterogêneas, principalmente em razão da disparidade da faixa etária e da escolaridade presentes em sala. Enquanto uma minoria nunca trabalhou ou teve contato com a área de vestuário, grande parte possui experiência como profissional autônomo ou em confecções. Nestes casos, é recorrente que a aprendizagem tenha se dado em ambientes domésticos, por meio de pessoas próximas ou com a utilização de esquemas de moldes prontos.

Acredita-se que as principais dificuldades enfrentadas pelos alunos na disciplina estão relacionadas a três questões: o problema de fazer a transposição mental entre as operações realizadas em uma forma bidimensional e suas consequências na forma que a roupa adquire ao ser vestida; falta de repertório geral de vestuário; e inexistência de material didático adequado para suprir essas dificuldades.

Usualmente, uma aula de modelagem plana tem um primeiro momento expositivo e outro de trabalho prático. Após a explicação do conteúdo, projeção de imagens e demonstração prática por parte do professor, os alunos partem para a construção dos moldes, geralmente a partir de um modelo básico extraído do livro. É comum que durante o processo apareçam dúvidas e o trabalho seja interrompido. As explicações verbais e visuais dadas pelo professor parecem não ser suficientes para a compreensão exata daquilo que se espera desenvolver. O material didático existente, por sua vez, não é satisfatório para dar suporte a esta lacuna e o processo de ensino-aprendizagem é interrompido pelas dúvidas, inseguranças e resistências enfrentadas pelos alunos. 


\subsection{Descrição da pesquisa realizada}

\subsubsection{Recurso pedagógico piloto}

No intuito de resolver os desafios enfrentados durante o processo de ensinoaprendizagem de modelagem, foi elaborado um recurso pedagógico piloto, composto por cerca de 50 peças de roupa (blusas, saias, camisas, mangas e vestidos) em meia escala, costuradas em algodão cru ou em tecidos de diversos tipos e estampas. Cada peça é acompanhada por seu molde em papel kraft $220 \mathrm{~g} / \mathrm{m}^{2}$ e pelo rascunho do molde com todas as marcações e desenhos de construção a lápis. As peças são organizadas por temas, de acordo com a programação da aula, e demonstradas em um manequim em meia escala.
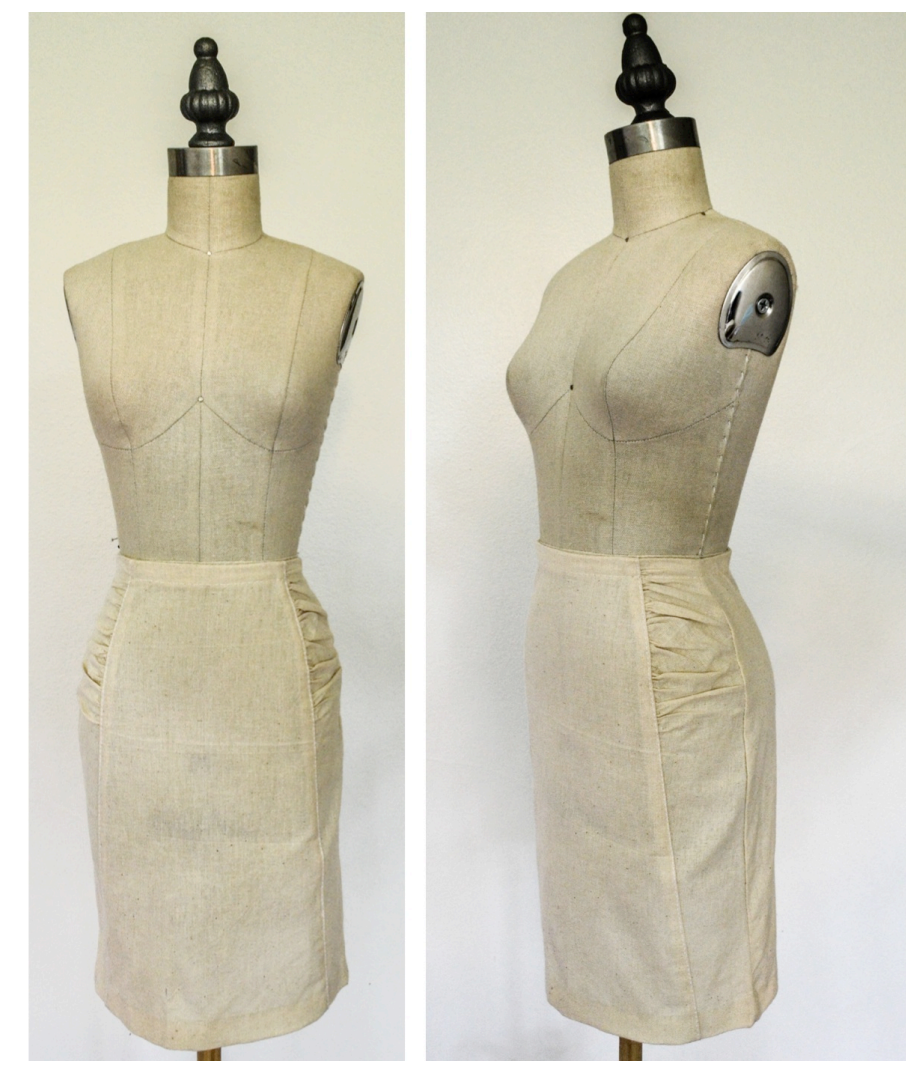

Figura 7 - Exemplo de peça do mostruário tridimensional - saia com franzidos laterais. Fonte: autora.

A ideia original era que o recurso pedagógico deveria fornecer uma diversidade de exemplos de vestuário com variedade de efeitos, caimentos e desenhos para livre consulta. Estes modelos poderiam ser manuseados, colocados no manequim e observados em busca de detalhes e acabamentos, de acordo com o interesse dos alunos. A expectativa era que este material fosse utilizado pelo professor durante a explicação do conteúdo, e também pelos alunos durante a feitura da modelagem. De um modo geral, o recurso deveria 
tornar mais fácil a aprendizagem de modelagem sem, no entanto, simplificar e reduzi-la a um conjunto de operações controladas. A princípio, serviriam apenas de referência ou inspiração para os trabalhos individuais, e não como modelo a ser copiado - embora essa possibilidade exista se o aluno desejar. A escolha da peça a ser consultada e a própria modelagem a ser desenvolvida, a partir dos exemplos selecionados, dependeriam das preferências individuais dos alunos, de acordo com seus interesses, confiança e disposição a novos desafios. Tanto aqueles que ambicionassem desenvolver uma modelagem complexa quanto os que desejassem uma mais simplificada poderiam escolher o molde mais adequado. Desta forma, o recurso seria receptivo às diferenças existentes em sala de aula.

\subsubsection{Workshop}

Para que o recurso pedagógico piloto pudesse ser avaliado e aperfeiçoado, foi necessário criar um ambiente de pesquisa que reproduzisse a complexidade existente em uma aula de modelagem. Considerando que a aprendizagem ocorre num cenário de um grande enredamento de sujeitos, interações, motivações, barreiras e resistências, não poderíamos criar uma situação demasiadamente controlada para verificar as consequências de um novo recurso pedagógico. Optou-se portanto, pela aplicação de uma pesquisa qualitativa na modalidade de um workshop de modelagem.

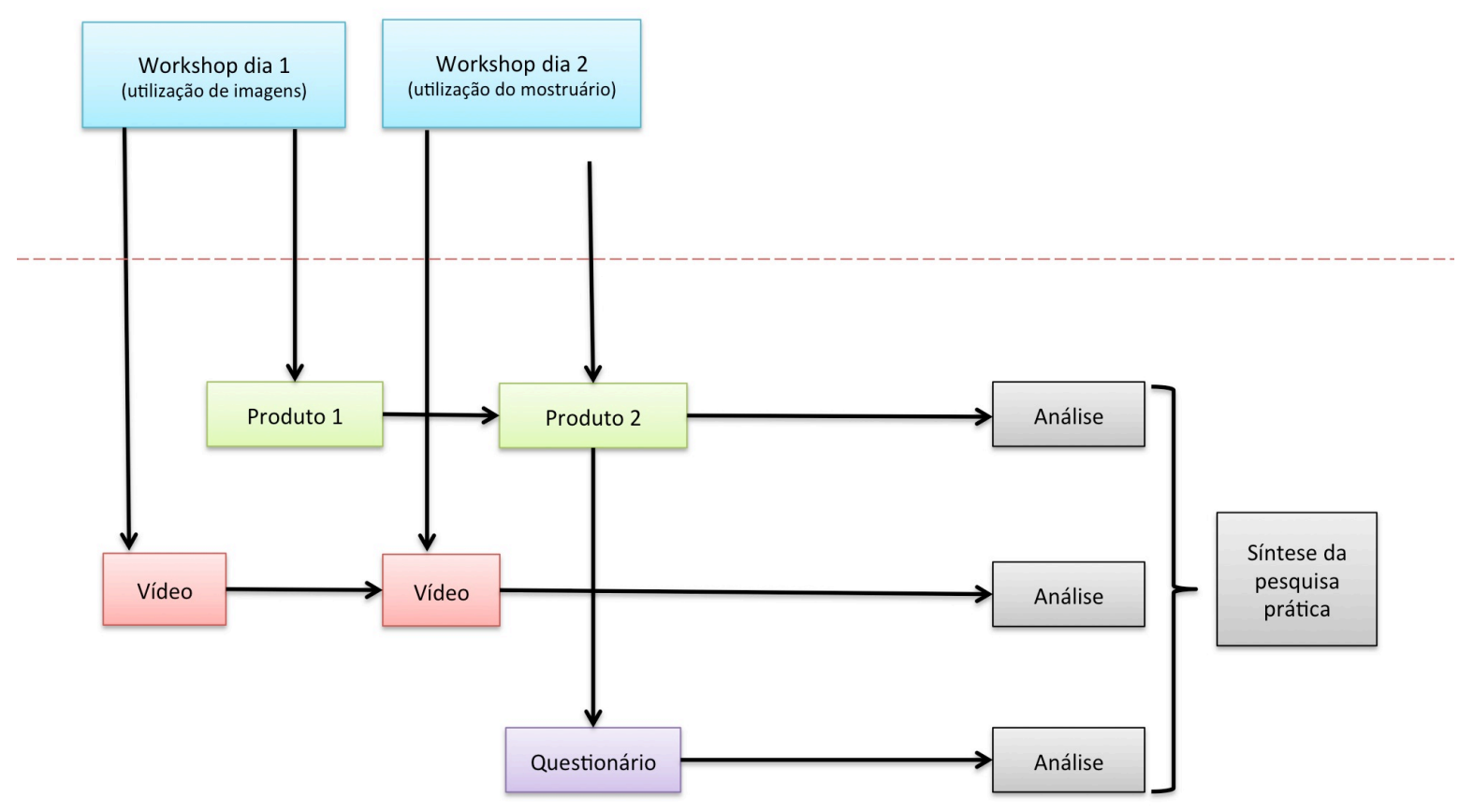

Figura 8 - fluxo de procedimentos da aplicação prática de workshop de modelagem. Fonte: autora 
A oficina teve duração de dois dias. No primeiro, utilizou-se uma metodologia tradicional, com explicações verbais, projeção de imagens e demonstrações práticas. No segundo dia, a aula foi complementada com a introdução do recurso pedagógico e consequente alteração da dinâmica em sala. Os encontros foram filmados e as modelagens produzidas pelos participantes foram fotografadas e analisadas. Ao final do curso aplicouse um questionário com nove perguntas fechadas.

O workshop "Módulo de Interpretação De Saias" foi ministrado no Instituto Federal de Brasília - campus Taguatinga - nos dias 14 e 15 de outubro, com carga horária total de 8 horas ( 4 horas em cada dia). O minicurso contou com 15 alunos dos cursos Técnico em Vestuário e Design de Moda. A participação foi aberta a todos os estudantes da instituição. O único pré-requisito foi que os alunos possuíssem noções básicas de modelagem. Assim, pôde-se trabalhar diretamente com a interpretação de modelos, prática que requer habilidades de visualização tridimensional, adequação da proporção, inovação formal, planejamento de encaixes e previsão dos acabamentos que serão realizados na etapa subsequente de costura.

No primeiro dia abordou-se o tema de "Recortes", que trata dos princípios gerais de como fragmentar uma peça para alterar sua forma final e foram utilizados os recursos tradicionais do ensino de modelagem. Após apresentação, deu-se início à aula expositiva, com projeção de imagens e demonstração prática. Em seguida, os participantes partiram para o trabalho prático individual e receberam orientações quando solicitadas. As imagens com sugestões de modelos permaneceram sendo projetadas no quadro durante toda a aula.

No segundo dia a proposta foi de se trabalhar com "Recortes e volumes", o mesmo processo básico do dia anterior, porém com a adição de volumes. A aula também foi iniciada com a apresentação do conteúdo e do trabalho a ser desenvolvido. Desta vez, além das imagens e demonstração, a aula expositiva foi complementada pelos exemplos físicos confeccionados em tecido. Foram apresentados seis exemplares de roupas em meia escala, que foram trocadas diversas vezes de acordo com o andamento da explicação, das dúvidas levantadas e das manifestações dos participantes. Antes de partirem para a modelagem individual os participantes foram convidados a manusear e investigar os protótipos. Na sequência, os alunos começaram a desenvolver seu trabalho individual, porém 
desta vez as peças estavam disponíveis para consulta e para serem levadas para a mesa de trabalho dos participantes.

Os participantes dispuseram de três horas para o desenvolvimento de suas modelagens. Ao final de cada dia, seus produtos foram fotografados e analisados em relação à complexidade, qualidade do desenho, detalhamentos, proporções e inovações.

Foram utilizadas duas câmeras de vídeo: uma estática, enquadrando todo o ambiente de modo ininterrupto; e outra móvel, capturando os gestos, manuseio de instrumentos e ferramentas, dúvidas e explicações individuais aos participantes. A intenção de filmar as ações individuais foi a de buscar diferenças no modo de se fazer a modelagem e de verificar o nível de autonomia em desenvolver suas modelagens. Observou-se a dinâmica da aula, fontes de consulta e o tempo de imersão nas tarefas sem necessitar de auxílio por parte do professor.

Na apresentação do workshop, todos foram informados que eram participantes de uma pesquisa. Foi pedido autorização para gravação de imagem e som somente para este fim. Todos concordaram e assinaram os termos de consentimento. Ao final do workshop os participantes foram convidados a responder um questionário anônimo estruturado com nove perguntas fechadas. Dessa forma, os aprendizes puderam comparar as duas situações e avaliar a relevância da utilização do modelo tridimensional em seu processo de aprendizagem.

\subsection{Análise dos dados e discussão dos resultados}

A experiência da realização da oficina e a análise do material produzido neste processo - vídeos, fotos dos produtos técnicos e questionários aplicados - revelaram que embora o recurso pedagógico tenha tido um alcance diferente para cada aluno, de uma maneira geral contribuiu positivamente para produtos mais criativos, para maior autonomia dos alunos em aula e para discussões mais amplas sobre o assunto. No entanto, ao contrário do que se esperava, os recursos não foram extensivamente consultados durante todo o trabalho de modelagem. Após o contato inicial, manuseio das peças e esclarecimentos das dúvidas iniciais, os participantes parecem ter exaurido as dúvidas e curiosidades sobre o material e prontamente debruçaram-se sobre o próprio trabalho. Como consequência, permaneceram mais tempo imersos e concentrados em suas próprias mo- 
delagens, o que resultou em trabalhos mais criativos, principalmente se comparados ao material produzido no primeiro dia.

\subsubsection{Análise do Workshop}

\section{Primeiro dia}

Conforme descrito anteriormente, o primeiro dia do workshop começou com a apresentação da proposta do curso. Na sequência, deu-se início à exposição do assunto a ser trabalhado em sala. A exposição oral foi acompanhada por projeções de imagens de referência e por uma demonstração prática de risco de uma modelagem. O repertório apresentado (imagens de cinco modelos de roupas) foram projetadas continuamente durante toda a manhã.

Os participantes foram então estimulados a criar seus próprios modelos, por meio de tentativas e erros, mas ficaram livres para escolher caso desejassem desenvolver um dos exemplos apresentados. Durante todo o workshop, a professora permaneceu disponível para orientações individuais e quando necessário, os comentários eram estendidos à toda turma. A maior parte dos alunos optou por desenvolver uma modelagem visando reproduzir um dos exemplares apresentados. Apenas alguns poucos (três de um total de quinze) desenvolveram produtos mais complexos ou interviram de maneira mais criativa nas modelagens.

\section{Segundo dia}

Após a demonstração da professora, os participantes levaram consigo os modelos confeccionados com seus respectivos moldes. Grande parte da interação com essas peças ocorreu no início da aula, antes de se iniciar a modelagem. Após examinaram o material, logo o deixaram de lado para dar início ao trabalho individual. Os participantes foram estimulados a criar seus próprios modelos, e não em reproduzir os protótipos, embora esta possibilidade estivesse aberta. Mesmo assim, constatou-se que o modelo físico foi utilizado apenas em momentos pontuais, com frequência menor do que se esperava. Uma explicação para este acontecimento é a que os alunos provavelmente sanaram as dúvidas que tinham naquele momento e estavam seguros para arriscar desenvolver sua própria modelagem. $\mathrm{O}$ fato dos modelos em tecido terem sido deixados de lado pelos participantes é um indício que o recurso pedagógico cumpriu seu papel enquanto material didático. Ao contrário dos materiais didáticos tradicionais em forma de passo-a-passo, este recurso 
permitiu e estimulou que os alunos verificassem livremente seus conhecimentos. $O$ trabaIho desenvolveu-se de forma mais fluida e contínua. As pausas para consultas foram gerenciadas pelos próprios participantes, ao invés de serem uma imposição externa desconectada do fazer, como acontece quando se segue obrigatoriamente uma sequência de etapas pré-definidas.

Os questionamentos durante o workshop em ambos os dias foram relacionados à costura e à interpretação dos modelos. Entretanto, no primeiro dia as dúvidas levantadas estavam desconectadas da prática. Perguntas soltas, do tipo "o que é revel?" foram feitas, enquanto que no segundo dias as perguntas estavam mais conectadas com o fazer. As perguntas agora eram do tipo: "Como eu procederia se eu desejasse fazer[...]" e "Se eu estivessem modelando tal peça, como saberia o formato correto de um revel?". Na sequência, houve um debate mais longo sobre o assunto de como planejar outros tipos de acabamentos interiores.

No entanto, ao contrário do que se esperava, a utilização do protótipo no segundo dia parece ter produzido mais dúvidas que no dia anterior. Porém, ao se comparar as dúvidas levantadas, verificou-se que as que seguiram a apresentação dos modelos em meia escala foram de maior complexidade e embasamento.

\subsubsection{Análise das Modelagens}

As modelagens realizadas pelos participantes podem ser vistas como um indício do aprendizado ocorrido na medida em que representam a síntese das compreensões, entendimentos, distribuição de esforços, auto regulação e capacidade de mobilização interna dos participantes. Obviamente, a verificação não se dá somente com base na avaliação do produto apresentado, já que este poderia ser o resultado de uma cópia ou ter sido feito com base em seus conhecimentos prévios, sem nenhuma nova aquisição. Para se ter um retrato mais abrangente da aprendizagem ocorrida, é necessário ter acesso às transformações ocorridas no sujeito pela observação da maneira como este compreende o problema, de suas escolhas, confiança, autonomia, lógica interna e da consciência de suas ações durante o fazer. Neste contexto, a análise do produto está vinculada às demais impressões obtidas pelos participantes durante a realização do workshop.

No primeiro dia, mesmo a repetição de modelos não sendo demandada, muitos ficaram focados em reproduzir os modelos projetados no quadro. Já no segundo dia, mes- 
mo havendo projeções de modelos, grande parte dos produtos foram inovadores e originais, tanto daqueles já experientes quanto dos iniciantes.

Em ambos os dias, os participantes que tinham mais dificuldades em aprender experientes ou não - optaram por modelos mais simples, e repetiram os modelos das projeções e dos protótipos. Embora o recurso não tenha sido pensado para ser copiado pelos alunos, esta ação é possível e não é necessariamente um problema para a aprendizagem, desde que não seja uma imposição de um agente externo. Se o professor estimula os participantes a tomar uma decisão consciente acerca do nível de dificuldade que eles mesmos irão enfrentar e se os próprios atores é quem fazem a escolha de forma consciente, não há razão para impedir.

A supressão da escolha e a imposição de um material didático com passo-a-passo para aqueles com mais dificuldades poderia fazer com que esse aprendiz se concentrasse em seguir o material, e não na prática de modelagem em si. Consequentemente, estaria mais distante de testar e conhecer seus limites.

Por si só, o aluno escolhe aquilo que acredita que será capaz de realizar na aula de acordo com as expectativas expostas. Obviamente, é inevitável que alguns subestimem e outros superestimem suas capacidades, conhecimentos e habilidades necessárias naquele momento para finalizar o desafio no prazo estipulado. Nos dois casos, os aprendizes estão conhecendo seus limites ou simplesmente aprendendo a gerenciar sua capacidade de mobilização interna - conhecimentos estes fundamentais para possibilitar o gerenciamento de sua própria aprendizagem.

Outro fato notório foi que alguns participantes decidiram fazer modelagens elaboradas no primeiro dia, porém não conseguiram concluí-las. No segundo dia, estes mesmo participantes puderam examinar as modelagens e verificar seu nível de complexidade para então optar por modelos mais simples e gerenciar melhor seu tempo para atingir os objetivos da aula. A comprovação de que o trabalho de modelagem é complexo é importante para que se possa compreendê-lo. Desse modo, segundo Trinquet, é que se pode conhecer, organizar, formar, prevenir os riscos do trabalho, organizar uma formação profissional e gerenciar eficazmente a atividade laboriosa (2010, p.96).

\subsubsection{Análise do Questionário}

O questionário estruturado foi aplicado no segundo dia, ao final do workshop. Seu objetivo era de verificar suas experiências prévias, as dificuldades encontradas ao se fazer 
modelagem, como o novo recurso foi utilizado e qual sua contribuição para o processo de aprendizagem dos participantes. Das nove questões, três permitiam mais de uma resposta e por esta razão os gráficos foram apresentados de maneira distinta.

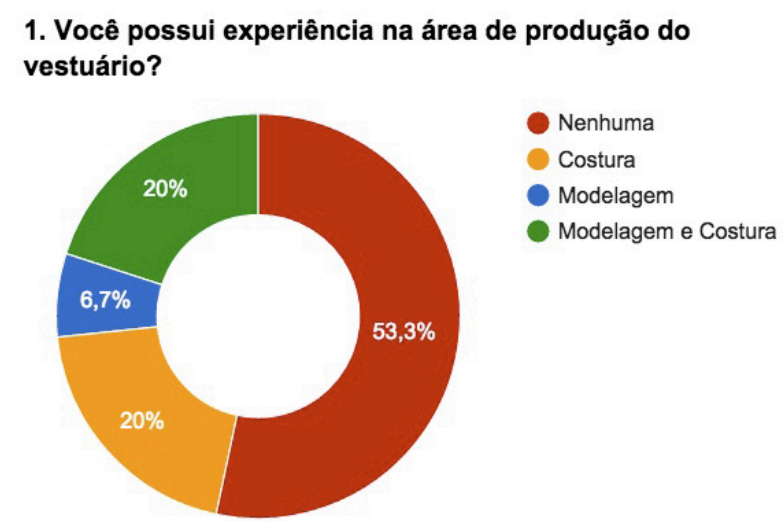

Gráfico 1 - Distribuição de respostas à questão 1 do questionário.

Inicialmente foi indagado se os alunos possuíam experiência em produção do vestuário. Desejava-se saber se o protótipo iria impactar tanto os alunos iniciantes quanto aqueles que já possuíam algum conhecimento na área. Pouco menos da metade possuía alguma experiência em modelagem, costura ou ambos.

2. Quais são as principais dificuldades ao se fazer modelagem?

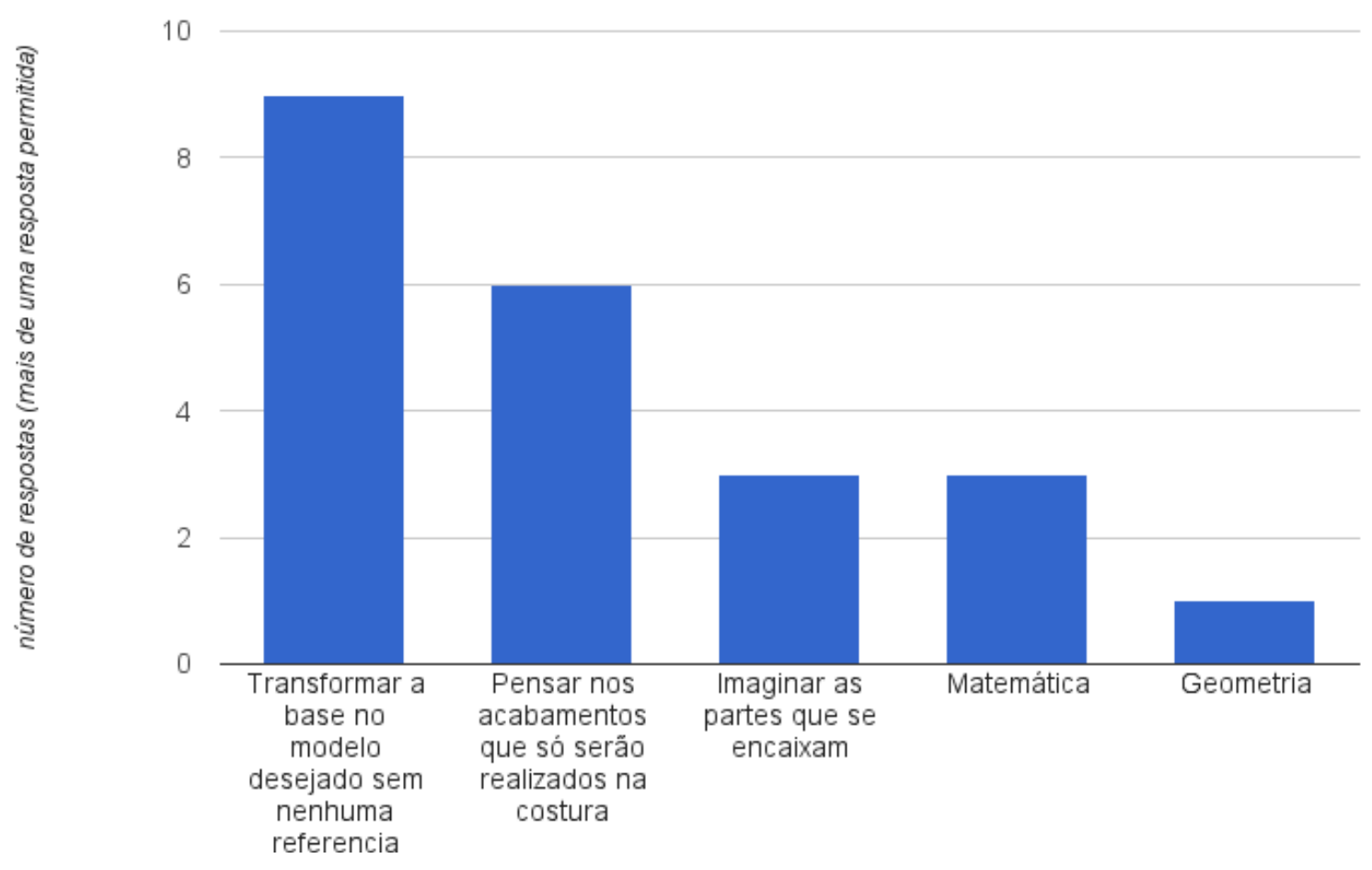

Gráfico 2 - Distribuição de respostas à questão 2 do questionário. 
Na segunda pergunta os participantes poderiam marcar mais de uma resposta, já que pretendia-se saber quais as principais dificuldades enfrentadas no processo. $O$ item que mais se destacou foi a dificuldade de transformar o molde base no modelo desejado sem nenhuma referência para consulta. Este processo requer confiança, pois não consiste apenas em memorização de etapas ou de repetição, mas demanda imaginação dos encaixes, criatividade, senso de proporção e precisão. É nesta etapa que é pensada e definida a forma final do produto, já que cada modelo possui suas especificidades. Esses desafios podem fazer com que haja um momento de dúvida e até insegurança no sujeito toda vez que se inicia o processo de interpretação do modelo. A segunda alternativa mais marcada foi a de pensar nos acabamentos que só serão realizados na etapa subsequente - na costura. Refletir sobre esses detalhes exige um repertório dos tipos de costura, e depende basicamente da memorização e repetição. Uma vez que esses detalhes são conhecidos, é possível esquematizar os fechamentos da peça durante a feitura da modelagem. Matemática e geometria, por sua vez, apesar de serem conhecimentos básicos e necessários ao desenvolvimento do trabalho, foram as alternativas menos marcadas na questão. Mas o fato de terem sido assinaladas revela que, para alguns participantes, é necessário um reforço de questões básicas para que não causem obstáculos à aprendizagem.

\section{A aprendizagem de modelagem plana possui dificuldades com relação à visualização tridimensional do produto final?}

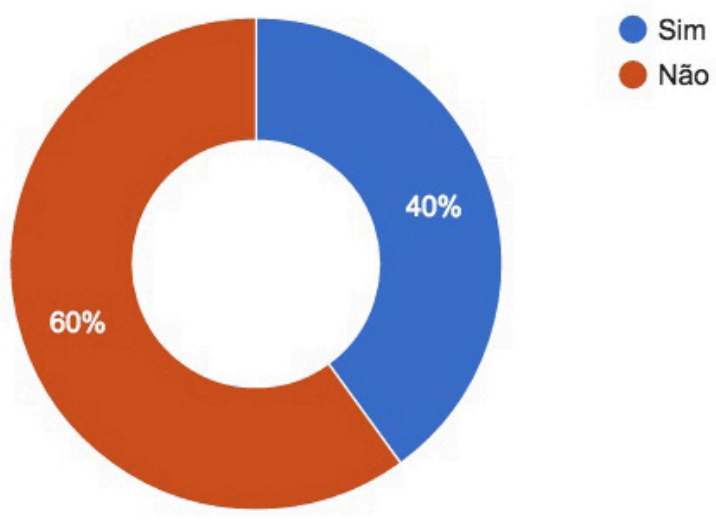

Gráfico 3 - Distribuição de respostas à questão 3 do questionário.

Na sequência, buscou-se investigar se a modelagem plana apresentava dificuldades em relação à visualização tridimensional, uma das principais hipóteses deste trabalho. Essa habilidade é exercitada nesse tipo de atividade que envolve a transformação do modelo. Para $40 \%$ dos participantes, há dificuldade em se imaginar a peça acabada em sua 
forma final. Dos que assinalaram positivamente a esta questão, dois terços não possuíam experiência na área. Isto pode indicar que o recurso provavelmente terá uma contribuição maior nesta questão tão recorrente no ensino desta disciplina.

\section{Você avalia que o protótipo tridimensional da modelagem facilitou $o$ aprendizado?}

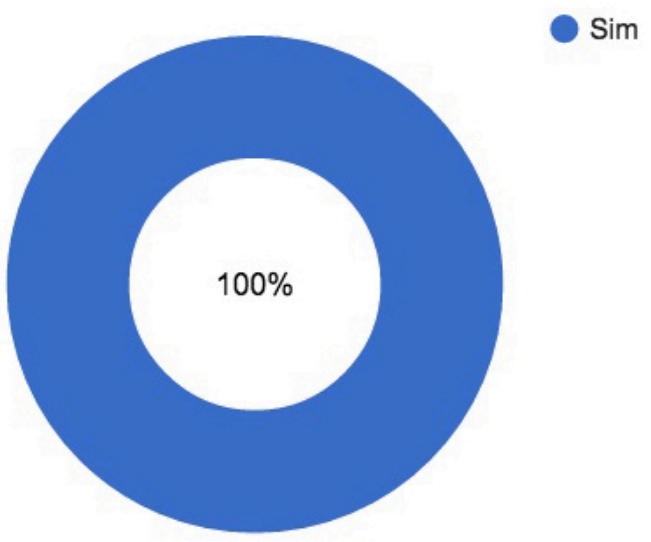

Gráfico 4 - Distribuição de respostas à questão 4 do questionário.

Mesmo com a diversidade existente na sala de aula e a consequente variedade e intensidade de formas com que os recursos pedagógicos foram apropriados, houve unanimidade em afirmar que este promoveu uma melhoria de alguma forma na aprendizagem dos participantes. As próximas perguntas foram feitas com o objetivo de se saber o alcance, intensidade e de que maneiras esta ferramenta foi utilizada durante o workshop.

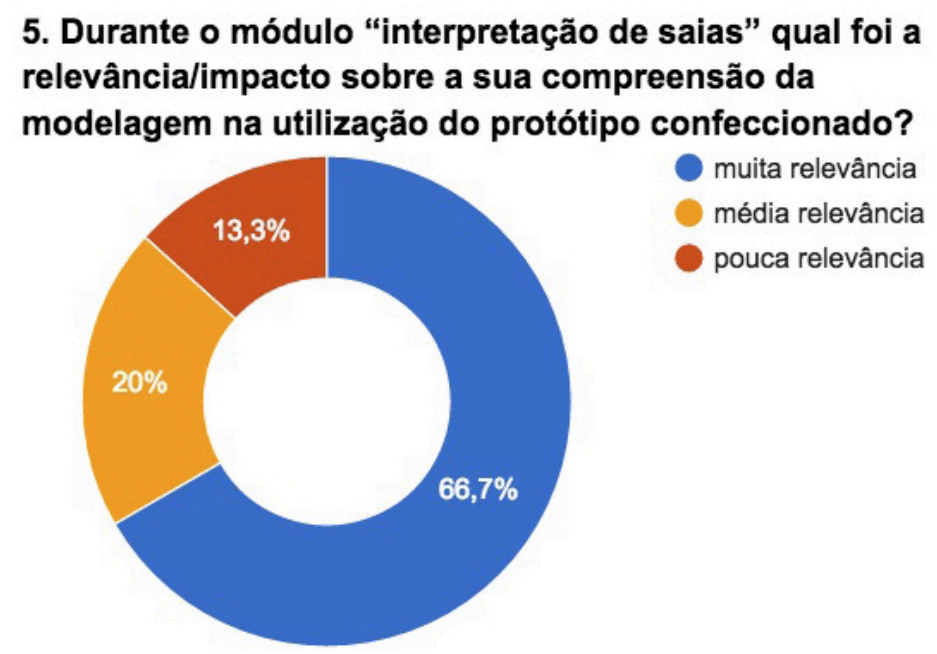


Na questão 5, dois terços dos entrevistados afirmaram que a utilização da peça de roupa do recurso pedagógico foi muito relevante para a compreensão da modelagem. Os demais $20 \%$ relataram que o recurso teve média relevância e os restantes $13 \%$, pouca relevância. Como todos os participantes afirmaram que o protótipo produziu melhorias na aprendizagem, acredita-se que aqueles que afirmaram que ele teve pouca relevância podem já ter um conhecimento prévio consolidado do assunto ou da atividade proposta, já que havia alunos de módulos avançados no workshop. Nestes casos, as peças apresentadas podem não ter apresentado nenhuma novidade significativa. Isto não quer dizer que a aprendizagem não ocorreu, apenas que pode ter sido a assimilativa, que ocorre quando são adicionadas novas informações a um esquema preexistente, sem grandes esforços cognitivos ou emocionais. Em todo caso, ao ser detectado este tipo de situação, é necessário uma investigação para saber quais os reais motivos baixa relevância - se por questões cognitivas, motivacionais ou de interação. Somente então pode-se propor uma ação pedagógica, seja ela de aumentar o desafio e a complexidade ou de buscar um outro modelo de maior interesse do aluno.

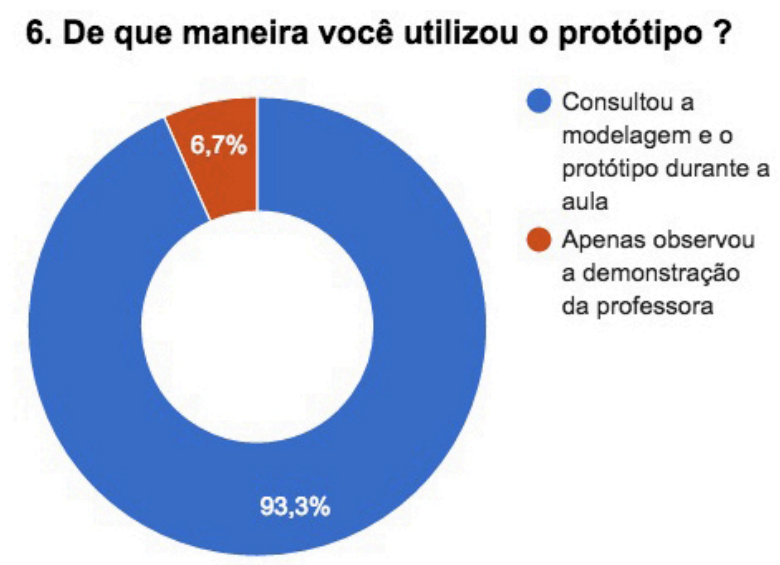

Gráfico 6 - Distribuição de respostas à questão 6 do questionário.

O item 6 buscava saber de que maneira o aluno interagiu com o protótipo. Apenas um participante afirmou que observou a explicação e demonstração prática da docente, e não utilizou o modelo durante a aula. Como todos participantes declararam que o protótipo melhorou a aprendizagem, a hipótese é de que o modelo tridimensional parece ter influenciado na explicação e demonstração prática da docente. Acredita-se que o momento expositivo possa ter tido um alcance maior com os protótipos para as dúvidas desse participante que não precisou consultá-los. A maior parte dos alunos relatam ter buscado auxílio nos modelos físicos durante a aula para esclarecer dificuldades encontradas na prática. 
7. Se você consultou a modelagem e o protótipo durante a aula, foi com qual finalidade?

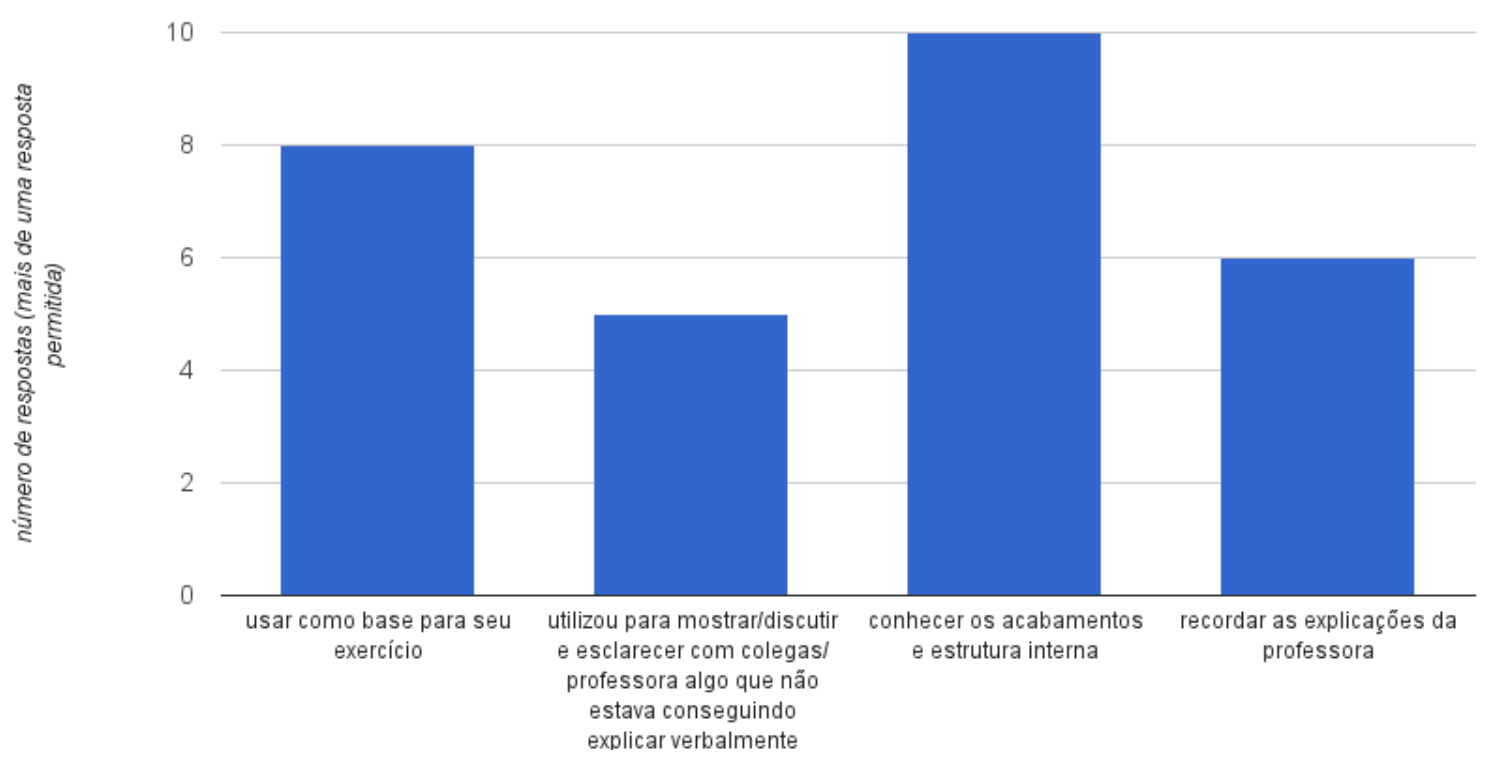

Gráfico 7 - Distribuição de respostas à questão 7 do questionário.

A questão 7 buscou saber com quais finalidades os modelos tridimensionais foram utilizados durante a atividade. As respostas revelaram que grande parte dos participantes estavam interessados primeiramente em conhecer os acabamentos e estrutura interna do modelo e em segundo lugar, usá-los como base para o exercício. Essas duas motivações vão de encontro com as duas principais dificuldades em modelagem relatadas na questão 2 - modelar sem o auxílio de referências e pensar nos acabamentos realizados na etapa de costura. O trabalho desenvolvido durante o workshop priorizou a etapa de desenvolvimento/interpretação da modelagem. Essa etapa de construção do molde é desafiadora, pois cada modelo mobiliza um raciocínio diferente e requer conhecimentos dos setores de reprodução como corte e costura. Assim, as peças em tecido acompanhadas por suas respectivas modelagens no papel serviram como guia desse processo.

Utilizar o protótipo para recordar as explicações da professora, foi outro motivo apontado por um terço dos participantes. Acredita-se que o modelo serviu como recurso para memorizar e esclarecer as explicações do docente. Por se tratar de um modelo físico, essas recordações são estimuladas através do contato tátil, da observação individual e da experiência visual com o modelo transformado. O objeto desperta reflexões que são resolvidas pela própria investigação autônoma, pois o conteúdo teórico está incorporado no modelo confeccionado. O sujeito pode se concentrar no planejamento dos encaixes, na proporção, e no resultado final. Nos casos em que os conteúdos são abordados por meio 
de material didático escrito e ilustrado com o passo-a-passo, a aprendizagem é voltada para um processo com conteúdos matemáticos e geométricos. "Se a linguagem antecipa a ação por meio de normas, esta supera e transgride a primeira, sendo sua fonte de reatualização" (CUNHA, D. M., 2010, p.61).

\section{Você acha que o protótipo melhorou seu modo de fazer modelagem quando comparado à modelagem feita no dia anterior?}

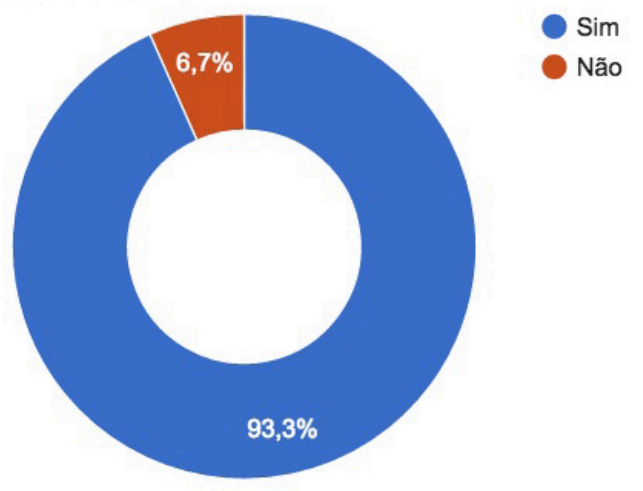

Gráfico 8 - Distribuição de respostas à questão 8 do questionário.

Ao se questionar se o protótipo melhorou o modo de fazer modelagem quando comparado ao dia anterior, a quase totalidade dos participantes respondeu a questão 8 afirmativamente. Apenas uma resposta foi negativa e as possíveis razões para esta resposta negativa já foram expostas na análise da questão 5.

9. Se sim, de que maneira?

10

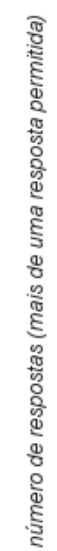

8

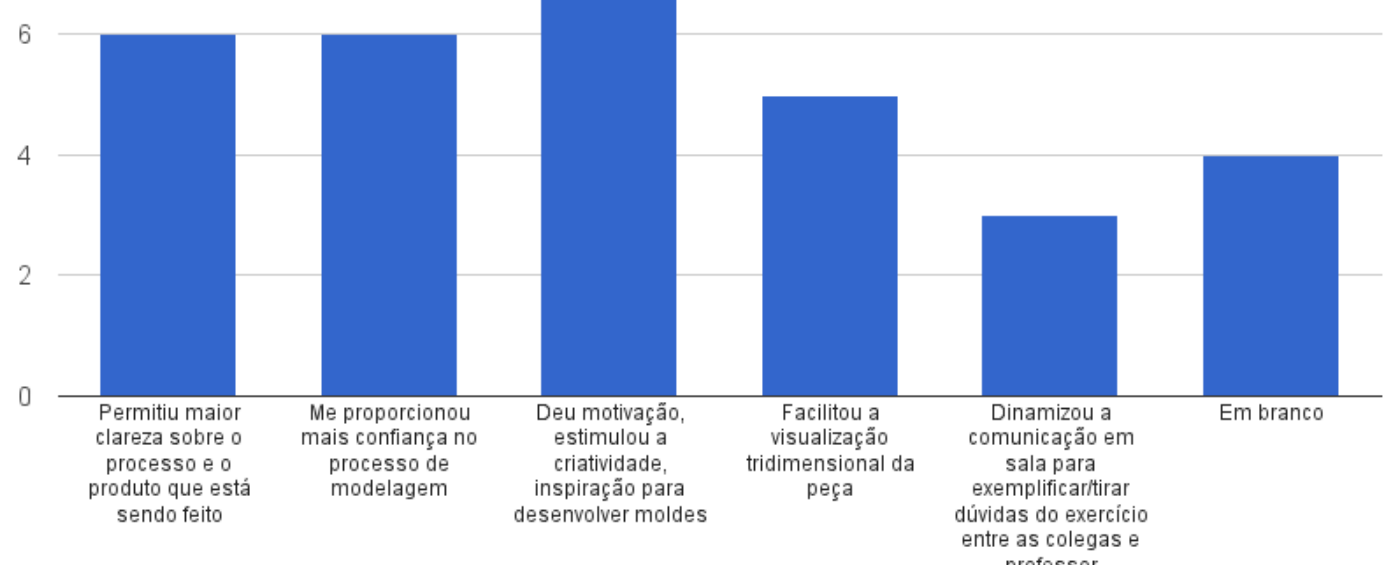
professor

Gráfico 9 - Distribuição de respostas à questão 9 do questionário. 
O item 9 buscou saber de que maneira o protótipo melhorou o modo de fazer modelagem dos participantes. Estes relataram que "a motivação, o estímulo à criatividade e a inspiração para desenvolver moldes" foi a principal melhoria no processo de aprendizagem durante a interação com os modelos tridimensionais. Na sequência, as melhorias mais apontadas foram a de proporcionar mais confiança e de dar maior clareza sobre o processo e produto em desenvolvimento.

A primeira revela uma contribuição predominante na dimensão do incentivo. Os protótipos podem ter colaborado para estimular a vontade interna para aprender modelagem, tornando a prática interessante e motivadora para os sujeitos. Os participantes puderam tomar decisões durante o desenvolvimento do trabalho, conduzindo seu próprio processo, solucionando os imprevistos e criando os modelos de seu interesse. Como colocou D. M. Cunha, "a possibilidade de protagonizar o próprio processo de aprendizagem é prazeroso, e dá um novo significado à experiência pedagógica vivenciada" (1998, p.103).

A outra mostra uma contribuição do recurso na dimensão do conteúdo e também da interação, pois a clareza que os moldes forneceram sobre o processo e o produto meIhora a comunicação e abre espaço para a cognição. Visualizar e manusear a roupa pronta (acompanhada por sua modelagem) fornece ao participante uma série de informações sobre o produto muito mais esclarecedoras que qualquer descrição verbal ou escrita. O aluno tem uma noção mais clara de como seu produto deve se tornar ao final do processo. Este esclarecimento imediato libera mais tempo da aula e mais energia mental para a produção individual e para o desenvolvimento de seu produto.

A exposição deste objeto também conduz e orienta o processo na medida em que serve de guia e referência para que os iniciantes não se percam durante o fazer. Desta maneira, a imersão individual na tarefa de modelagem plana, com suas formas abstratas, imaginação e planejamento do produto ganha mais significado.

A interação e comunicação entre professor/aluno obteve menos destaque, assim como apontado pelas respostas de igual teor à pergunta número 7. Desse modo concluise que as contribuições mais significativas encontram se nas dimensões de incentivo e cognição, embora seja possível afirmar que também houve alteração na qualidade da interação, já que todas as dimensões estão interligadas em todo processo de aprendizagem. 


\section{Considerações}

Esta pesquisa revelou resultados que levantaram importantes considerações sobre a utilização e os efeitos do protótipo no processo de ensino-aprendizagem. De uma maneira geral, os participantes trabalharam por mais tempo, de maneira mais concentrada e produziram modelagens mais criativas que na experiência anterior. As discussões iniciais mostraram-se mais abrangentes e as dúvidas foram esclarecidas com maior facilidade na presença de um modelo físico. Outro dado significativo foi que a diferença de desempenho entre os alunos experientes e os iniciantes diminuiu no segundo dia.

Os participantes consultaram os modelos no início da aula, e logo o abandonaram para desenvolver suas próprias modelagens. O material foi de certa maneira superado, isto é, cumpriu seu papel de suprir um conjunto de dúvidas, esclarecimentos e curiosidades existentes antes de se iniciarem os trabalhos individuais e logo tornaram-se dispensáveis. Eles continuaram disponíveis para consulta, mas os participantes não sentiram necessidade de recorrer sempre a ele. Isto sugere que ele contribuiu para promover maior autonomia dos aprendizes, já que estes não ficaram dependentes de um recurso do mesmo modo que ficam quando devem seguir um roteiro passo-a-passo e têm seu fluxo de trabalho interrompido constantemente.

Esta autonomia, no entanto, não é mero resultado da utilização do recurso pedagógico, mas do modo como a atividade foi conduzida, já que eles puderam trilhar seu próprio caminho. Mesmo assim, alguns poucos optaram por desenvolver modelos mais básicos, ou até iguais aos protótipos. Isso revela sobre o tipo de aprendizagem que estavam aptos a desenvolver naquela situação específica, seja por questões cognitivas ou motivacionais.

Diferentemente do primeiro dia, no qual os experientes tiveram uma performance geral melhor que os inexperientes, no segundo dia houve um nivelamento entre os participantes. Ambos se comportaram de maneira muito similar em relação ao nível de concentração, ao tipo de pergunta e à modelagem produzida.

O contato físico com os modelos parece ter intensificado a experiência com o objeto, pois este possui qualidades tridimensionais, estímulos visuais e táteis que uma imagem projetada simplesmente não possui. Acredita-se que isto contribui para uma experiência rica e instigante, impactando positivamente na motivação e confiança dos participantes. Isto explicaria a grande quantidade de produtos inovadores quando comparados com o 
dia anterior. Acredita-se também que os protótipos supriram as dúvidas básicas com maior rapidez e de maneira mais ampla que quando apenas explicações verbais foram utilizadas. Ao manusear os objetos, os participantes puderam tirar suas conclusões por conta própria a partir da experiência tátil, observação e constatação, fortalecendo seu saber adquirido.

Esta consolidação dos conhecimentos básicos, que se caracteriza pela formação de um esquema de conteúdos, é que permite um aumento na quantidade e na complexidade de futuras aprendizagens na área, pois é sobre esta estrutura básica que os demais conteúdos e conhecimentos se acoplam no caso de uma aprendizagem associativa. Se a estrutura inicial não tiver uma base sólida, eventualmente será necessário uma desconstrução e rearranjo desta estrutura para que novos conhecimentos sejam incorporados. Neste último caso, as resistências, barreiras e o esforço geral necessário para que a aprendizagem aconteça serão muito maiores.

No caso de indivíduos experientes, que possuem um conjunto de conhecimentos e saberes construídos com grande esforço, por meio de tentativas e erros, este processo torna-se muito mais dispendioso. Não é simples desistir de esquemas que nos esforçamos tanto para adquirir e que, de algum modo, nos habituamos a construir (ILLERIS, 2007 p.43). Aprender, para esses alunos, pode exigir mais empenho emocional para desmontar o que já está assimilado e criar espaço para a absorção de algo novo. Esse movimento pode confrontar o aluno com sua cultura, sua prática de trabalho, seus hábitos e seu modo de viver. Nestes casos é preciso suporte do professor para ajudar o aluno a atravessar as dificuldades, desenvolver sua autonomia e compreender sua própria experiência.

Outras constatações foram feitas após a análise do material e reflexão pósworkshop. Notou-se que os exemplos mais consultados pelos participantes tinham uma modelagem mais contemporânea enquanto que os modelos mais antigos não despertaram grande interesse, principalmente entre os mais jovens. Também foram observadas alguns detalhes técnicos das peças que deveriam ser revistos, principalmente aquelas relacionadas à composição de tecido, estampas e cores. Verificou-se que algumas dúvidas poderiam ter sido sanadas se houvesse uma ficha técnica de cada conjunto de peça. No entanto, a constatação mais significativa do workshop foi aquela relacionada à aprendizagem. Acreditamos que esta é maior, em alcance e em complexidade, que qualquer recurso pedagógico e que o papel de qualquer material didático é o de dar um suporte silencioso a este processo. Um material didático não pode se impor sobre o aluno ou ter a pretensão 
de controlar totalmente o processo de aprendizagem sem reduzi-lo de maneira simplista. Neste sentido, o modo como o material foi esquecido sobre a mesa enquanto os alunos se debruçavam sobre seu trabalho revelou que ele cumpriu sua função de dar suporte aos processos de construção do conhecimento. 


\section{Capítulo 3 - Produto técnico}

[...] uma mudança na educação preocupada com o significado do sensorial é extremamente necessária para que nós possamos nos redescobrir como seres físicos e mentais, de usar plenamente nossas capacidades, e nos fazer menos vulneráveis à manipulação e à exploração (PALLASMA, 2009, p.21).

Encontrar um recurso material que não demande experiência prévia e que sirva de intermédio entre a teoria e a prática será um facilitador da aprendizagem tanto para aqueles que já possuem um conhecimento na área quanto para os iniciantes. Um recurso pedagógico na forma de objeto apela para uma necessidade primitiva física de tocá-lo. "A união do olho, da mão e da mente cria uma imagem que não é só uma recordação visual ou a representação do objeto, e sim é o próprio objeto" (PALLASMAA, 2009, p.82).

O repertório não será baseado apenas na projeção da imagem ou da explicação verbal - que estão no campo da abstração - mas será uma memória por meio do contato com o concreto, baseada na experimentação tátil e incorporado na própria experiência de vida. Alterar a interação dessa situação de aprendizagem - que só se realizaria por meio do imaginário subjetivo - para uma que utiliza como meio a manipulação corporal e a observação é enriquecer o processo cognitivo. É dar condições para o aluno antecipar as situações que ainda não ocorreram e encontrar motivação para desenvolver processos mais abstratos e complexos.

De uma maneira geral, os alunos mais experientes apresentam uma certa resistência à aprendizagem, pois estão há anos executando os trabalhos de modelagem da única forma que conheceram. Por vezes não puderam renovar seus conhecimentos ou quando tiveram a oportunidade o curso foi insuficiente para se descontruir a estrutura existente. Esse contato com o elemento material pode proporcionar uma certa distância de suas experiências anteriores, já que fazer uma modelagem possui um cunho emocional, muitas vezes ligadas à trajetória de vida, à necessidade, à sobrevivência.

A ideia é de unir os alunos por meio da matéria concreta, e sem o sentimento de exclusão ou de comparação, o grupo torna-se mais coeso e cooperativo, melhorando o ambiente de aprendizado. 
A relação sujeito-objeto forma o cognato e o núcleo de uma epistemologia. Aquilo que é 'objeto', podemos olhar, assumir responsabilidade por ele, refletir sobre ele, exercer controle sobre ele, integrá-lo com algum outro modo de saber. Aquilo que é 'sujeito' nos controla, nos identificamos com ele, nos fundimos com ele, sofremos seu efeito (KEGAN, 2013, p.58).

Quando pensamos na criação de um recurso pedagógico, é necessário ter em mente seu papel enquanto instrumento catalizador de processos complexos e plurais. Portanto, é imperativo que esta ferramenta corrobore para a implementação de um ambiente estimulante à aprendizagem. Para tanto, sua utilização deve possibilitar que esta ocorra de um modo não linear, de acordo com a iniciativa dos aprendizes. Também deve ser possível que o mesmo material possa ser abordado sob diferentes perspectivas e aspectos.

Em termos práticos, os trabalho de modelagem consiste em desenhar as formas planas que, ao serem unidas, formarão a roupa que cobrirá um corpo tridimensional. As consequências das decisões tomadas no plano bidimensional só serão vistas quando cobrirem um corpo e se tornarem um volume. Neste ponto é que reside grande parte das dificuldades enfrentadas pelos aprendizes.

Assim sendo, o material didático deverá dar suporte a este processo de transposição entre planos e volumes. Ele deverá ser ao mesmo tempo uma fonte de repertório e de inspiração. Os exemplos precisarão ser de situações de modelagem com seus problemas e dificuldades enfrentados como na vida real. O material deve ser físico, possível de ser manuseado, observado e investigado. Que não demande experiência prévia, porém que tenha complexidade suficiente para que um olhar mais atento possa descobrir algo novo. Ele precisa estar disponível para consulta e para servir de referência para o processo do aprendiz. O recurso pedagógico deverá conter uma quantidade razoável de exemplos para esclarecer as principais dúvidas quanto aos efeitos, caimentos, cortes, costura, acabamentos de cada tipo de vestimenta (calças, saias, camisas, etc). Além das dúvidas de modelagem, o recurso também deve fornecer informações relativas à costura, sequência de montagem, acabamentos, margens de costura, e outras questões relacionadas à prática. Em suma, deve expor todo o processo.

É necessário que o material tenha como base um sistema aberto para permitir diversas abordagens pedagógicas, considerando que será utilizado por outros professores e facilitadores. Sua utilização deverá tornar mais fácil a aprendizagem de modelagem plana, abrindo espaço para que os alunos se coloquem de maneira ativa e gerenciem seu próprio processo. Com isso possibilita-se um ambiente mais favorável à diversidade existente em 
sala de aula, permitindo situações mais estimulantes e intensas. Finalmente, este recurso não pode ter a pretensão de ser a palavra final no ensino de modelagem, mas apenas o ponto de partida para um processo igualmente vivo e dinâmico.

\subsection{Apresentação do produto técnico}

A ideia para este recurso pedagógico surgiu durante a prática docente, com o intuito de contribuir para a melhoria da aprendizagem de modelagem. A constatação das dificuldades enfrentadas pelos alunos em relacionar a modelagem plana com a peça ainda a ser confeccionada sugeriu que a utilização de modelos físicos pudesse estimular o processo de visualização tridimensional, ampliar o repertório de soluções técnicas e motivar os alunos para a aprendizagem.

O produto aqui apresentado, desenvolvido durante a elaboração deste trabalho, tinha como objetivo principal facilitar os processos cognitivos de aquisição de conhecimento de modelagem plana. No entanto, com o aprofundamento da teoria de aprendizagem de Knud Illeris (2007) e das questões relacionadas ao trabalho real (TRINQUET, 2010), expandiu-se o escopo quanto ao papel do recurso pedagógico e seu potencial enquanto facilitador dos processos de aprendizagem. A posterior aplicação prática durante o workshop de modelagem permitiu o aprimoramento de algumas questões técnicas e sobretudo enfatizou seu papel enquanto mediador dos múltiplos processos de aquisição que ocorrem em um mesmo ambiente educacional.

\section{Objetivo}

Este recurso pedagógico tem como objetivo, além de tornar mais fluida a aprendizagem de modelagem, contribuir para o processo como um todo. Do ponto de vista didático, este recurso é uma compilação organizada de modelos, modelagens, efeitos, materiais, tipos de costura e acabamentos utilizados na produção do vestuário. É um material que carrega um conjunto de conhecimentos que estão depositados nas próprias peças. Estes saberes estão ali, disponíveis para serem desvendados por aqueles que se interessarem. O material em si é uma ferramenta passiva que repousa sobre a mesa aguardando ser manuseada. Ao invés de projetar-se sobre o aluno, tornando-o agente passivo, este recurso aguarda o contato e manuseio por um sujeito ativo com um olhar investigativo. Neste sentido, é uma ferramenta aberta que convida a uma abordagem plural sobre o assunto. 
A aquisição de conhecimento depende de uma situação de interação que produza estímulos no sujeito ali presente. Estes estímulos são confrontados ao mesmo tempo com seus conhecimentos e suas emoções. A depender da configuração resultante, e da disponibilidade para a mobilização interna, a aprendizagem acontece. Em todos os casos há sempre um campo de tensão entre interação, conhecimentos existentes e motivação. Como cada sujeito é único, teremos sempre uma considerável variedade de situações e configurações subjetivas (MITJAN-MARTINEZ, 2005) em sala de aula.

Isto é, uma melhoria na comunicação pode gerar um avanço na cognição e incentivo ou então uma melhora na confiança pode impactar positivamente a aquisição e a interação. Consequentemente, uma modificação bem sucedida em questões didáticas pode ter um efeito muito mais abrangente do que se esperava inicialmente. Se a aprendizagem torna-se mais fácil, o aprendiz tende a sentir-se mais confiante. Se ele assume a responsabilidade de gerenciar seu próprio processo, cresce a probabilidade do professor tornar-se uma figura que irá ajudá-lo a superar este desafio, diminuindo os atritos entre ambos. Ou seja, ao se introduzir um novo recurso pedagógico, redesenha-se o campo de tensão da aprendizagem.

\section{Quanto às dimensões da aprendizagem}

Do ponto de vista dos conteúdos, este recurso pretende encurtar a distância existente entre o trabalho bidimensional da modelagem e seu produto final, a roupa. Pretende-se, com isso, fortalecer uma conexão entre as ações no campo abstrato e suas consequências no campo concreto. Ao se trabalhar com um material com propriedades físicas, prioriza-se a construção de conhecimentos nascidos a partir da própria observação da realidade. Essa presença e disponibilidade dos exemplos de cada etapa do processo (rascunho do molde, molde definitivo, peça piloto em algodão cru e peça finalizada em tecido) podem contribuir para que o aluno acompanhe o desenvolvimento de seu trabalho e não se perca em seu próprio fazer.

Com isso, ganha-se mais autonomia para gerenciar sua própria aprendizagem, independente da quantidade e qualidade de seus conhecimentos prévios. E geralmente esta autonomia vem acompanhada de maior segurança e disponibilidade de energia interna para dar suporte à aquisição de conhecimentos. E quanto maior for a disposição, motivação e abertura para este processo, maior as chances da aprendizagem acontecer. 
Do ponto de vista da interação, acredita-se que este recurso pode contribuir para a construção de um ambiente mais favorável para a aprendizagem. A utilização dos modelos em meia escala aumenta a quantidade e a variedade das informações disponíveis devido aos impulsos visuais e táteis que o contato com a roupa fornece. Esta ampliação de estímulos pode aumentar o alcance e a abrangência de uma situação de ensino, já que nem sempre uma explicação ou descrição verbal é a forma mais adequada e mais compreensível de transmissão de um determinado tipo de informação. Com a diminuição de desentendimentos e desinformação, libera-se mais espaço para que o aluno imerja em sua própria atividade e para que as discussões em sala sejam mais produtivas. Neste contexto, educadores e educandos beneficiam-se mutuamente com este ganho qualitativo no ambiente de ensino, já que todos buscam encontrar sentido e significado no próprio fazer.

\section{Quanto aos tipos de aprendizagem}

Quando colocado em perspectiva em relação aos tipos de aprendizagem (ILLERIS, 2007), acredita-se que este recurso tende à promoção de aprendizagens associativas em contraposição às cumulativas. Voltemos a um exemplo em sala de aula, na qual um aluno pergunta quantos centímetros deve ter a margem de costura. A consulta a uma apostila passa a passo forneceria um valor numérico que provavelmente seria memorizado, considerada uma aprendizagem cumulativa. No entanto, na presença de diversos modelos a disposição, esta resposta poderia tornar-se uma investigação visando uma descoberta de relações entre o tipo de peça, sua geometria, angulação, tipo de costura e acabamento final. Neste caso, esta informação pode fazer pequenas pontes de conexão entre diversos conhecimentos já adquiridos. Esta aprendizagem do tipo associativa pode ocasionar inclusive em maior solidez de outros saberes da área de modelagem.

No caso de situações nas quais houver a necessidade de se desconstruir um conhecimento já adquirido para que algo novo possa ser assimilado - aprendizagem acomodativa - espera-se que o material, sempre em conjunto com uma prática pedagógica encorajadora, forneça um conjunto de subsídios que assistam o aluno a completar este fadigoso processo acomodativo e eventualmente transformador.

\section{Resistências e defesas}

Embora haja uma expectativa geral que este recurso deverá tornar mais fluido o processo de aprendizagem de modelagem, não se espera que as resistências ou barreiras 
sejam suprimidas, já que estas dizem respeito ao aluno, à própria situação de interação ou outras questões subjetivas. Acredita-se apenas que um ambiente menos impositivo e mais autônomo permite que estas manifestações sejam mais transparentes, permitindo uma ação pedagógica mais eficiente. Igualmente espera-se que, ao melhorar a didática, aumentar a quantidade e variedade de estímulos e ao se trabalhar de maneira investigativa e livre, diminuem-se os desentendimentos de comunicação tão frequentes na prática docente. Estes pequenos lapsos podem ser uma grande fonte de frustração e predisposição a uma postura defensiva em sala de aula.

\section{Autonomia}

Outra questão significativa diz respeito à promoção da autonomia sobre a própria aprendizagem. Ao se instigar que os alunos façam suas escolhas sobre quais referências utilizar, nível de dificuldade da atividade e conteúdo a ser trabalhado, estimula-se que ele tome consciência que no fundo é ele o principal responsável por gerenciar seu processo de aquisição. Com isso, abre-se espaço para que o professor torne-se um colaborador de sua ação e trabalhe ao seu lado para superar as dificuldades desta empreitada. Com o aluno no centro do processo, é delegada a ele a missão de educar-se e exercitar a liberdade e a responsabilidade.

\section{Diversidade existente em aula}

Quando tentamos equacionar a complexidade dos processos de aprendizagem considerando a diversidade existente em sala de aula, somos compelidos a adotar um sistema aberto para poder entranhar-se por este emaranhado de situações. A heterogeneidade em sala é notável, cada vez mais temos alunos com diferentes idades, níveis socioeconômicos e formação convivendo em um mesmo ambiente educacional. Acreditase que um sistema aberto corrobora para um trabalho pedagógico mais abrangente, já que permite que a aprendizagem aconteça para um número maior de alunos e em um número maior de situações. Experientes e novatos, jovens e idosos, preparados e inexperientes podem participar em nível de igualdade neste processo. Mesmo aqueles que não tiveram uma boa base educacional poderão de fato ter algo em comum com aqueles com uma sólida formação sem que compartilhem das mesmas descobertas. Tanto os alunos de nível acima da média quanto os que estão abaixo dela poderão aprender respeitando-se sua situação. Trata-se, no fim das contas, de se pensar o ensino para o aluno real, e não pa- 
ra o aluno prescrito, como faz o ensino tradicional. Não se almeja tratar todos como iguais, mas pelo contrário, de reconhecer a condição única de cada um e a partir dela trabalhar para a construção dos conhecimentos aspirados.

\subsection{Descrição do produto técnico}

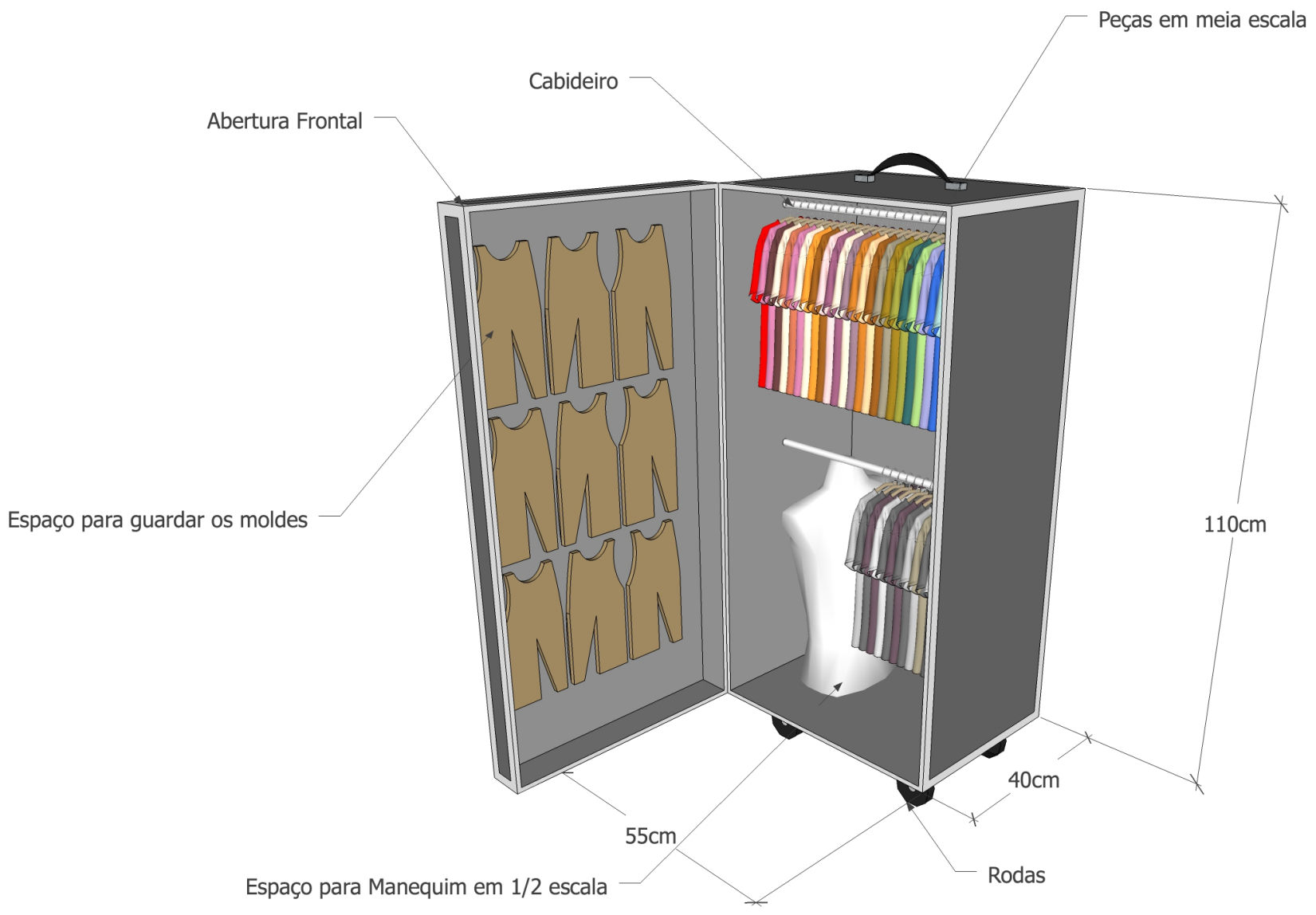

Figura 9 - Desenho esquemático do produto técnico. Fonte: autora.

O produto técnico pode ser descrito como um mostruário de peças de vestuário (blusas, mangas, saias, vestidos, casacos, calças, dentre outros) confeccionadas em tecido de diversas cores e estampas para ser utilizado como referência e consulta durante uma aula de modelagem. O catálogo é composto por diversos grupos de peças que podem ser utilizados de acordo com a necessidade do professor, e servirá como suporte ao momento expositivo e fonte de consulta antes e durante a feitura da modelagem. Está organizado em seções cujo conteúdo está relacionado aos conceitos e etapas básicas (bases, transfe- 
rências de pences, recortes, franzidos, pregas, golas) e outras mais avançadas. Sua classificação em modelo, efeito, detalhe e acabamento permite que o material possa ser utilizado em qualquer aula de modelagem em diversos níveis.

Os modelos representam as medidas ${ }^{4}$ de um manequim tamanho $40 \mathrm{em}$ meia escala. Optou-se por esta redução na escala de 1:2 em função da diminuição do consumo de material, facilidade de manipulação quando comparado com uma peça de roupa em grandeza real, e por ocupar pouco espaço na mesa de trabalho e no armazenamento. Utilizou-se um manequim técnico de produção nacional pela facilidade de acesso, já que é um produto disponível no mercado.

Em função do tamanho reduzido dos modelos, é necessário alguns cuidados na escolha do tecido e estampas. Os tecidos devem ser de gramatura fina para que as peças não fiquem demasiadamente rígidas e adquiram um caimento mais natural. Além disso, devem levar alguma fibra sintética em sua composição, para que não amassem com facilidade durante o manuseio e o armazenamento. Dentre as opções testadas, a tricoline mista (mescla) foi escolhida para simular os tecidos mais grossos e armados como o algodão e a sarja, enquanto o cetim com poliéster foi escolhido para representar aqueles com caimentos mais fluidos e leves, como o voal, a seda e outros.

Por fim, as cores foram utilizadas para distinguir as peças bases das peças acabadas. Para os modelos que se encontram nos estágios iniciais de modelagem optou-se por utilizar a cor cinza, que se destaca do manequim e valoriza as formas da peça. Nos modelos completos, que são modelagens que contemplam todas as etapas de construção do molde, optou-se por utilizar cores variadas para diferenciarem-se das bases. Nessas peças também são utilizadas estampas em escala reduzida e tecidos com direito e avesso diferentes para exemplificar cortes mais elaborados.

Os modelos são acompanhados de suas peças piloto e modelagens, produzidas também em meia escala, para que o aluno tenha acesso ao seu processo. A modelagem foi elaborada com um material que tivesse boa durabilidade - papel kraft de $340 \mathrm{~g} / \mathrm{m}^{2}$. Entretanto esse material não foi considerado definitivo se sua produção fosse ampliada. Primeiro é preciso ainda observar seu uso e quais danos podem surgir com a incidência da

\footnotetext{
4 de acordo com o livro. "Modelagem industrial brasileira". DUARTE, Sonia; SAGGESE, Sylvia. Rio de Janeiro: Sonia Duarte e Sylvia Saggese, 2010.
} 
umidade, sujidade e amassados. Outro quesito são as sinalizações que são feitas manualmente, como margem de costura, fio, piques. Na eventualidade de sofrerem danos, as modelagens podem ser facilmente copiadas manualmente no $\mathrm{kraft} 340 \mathrm{~g} / \mathrm{m}^{2}$. O mesmo pode ocorrer com os modelos tridimensionais, pois suas modelagens estão prontas. Se algum for danificado pelo seu uso - manchas, cortes e rasgados - basta produzir a peça novamente.
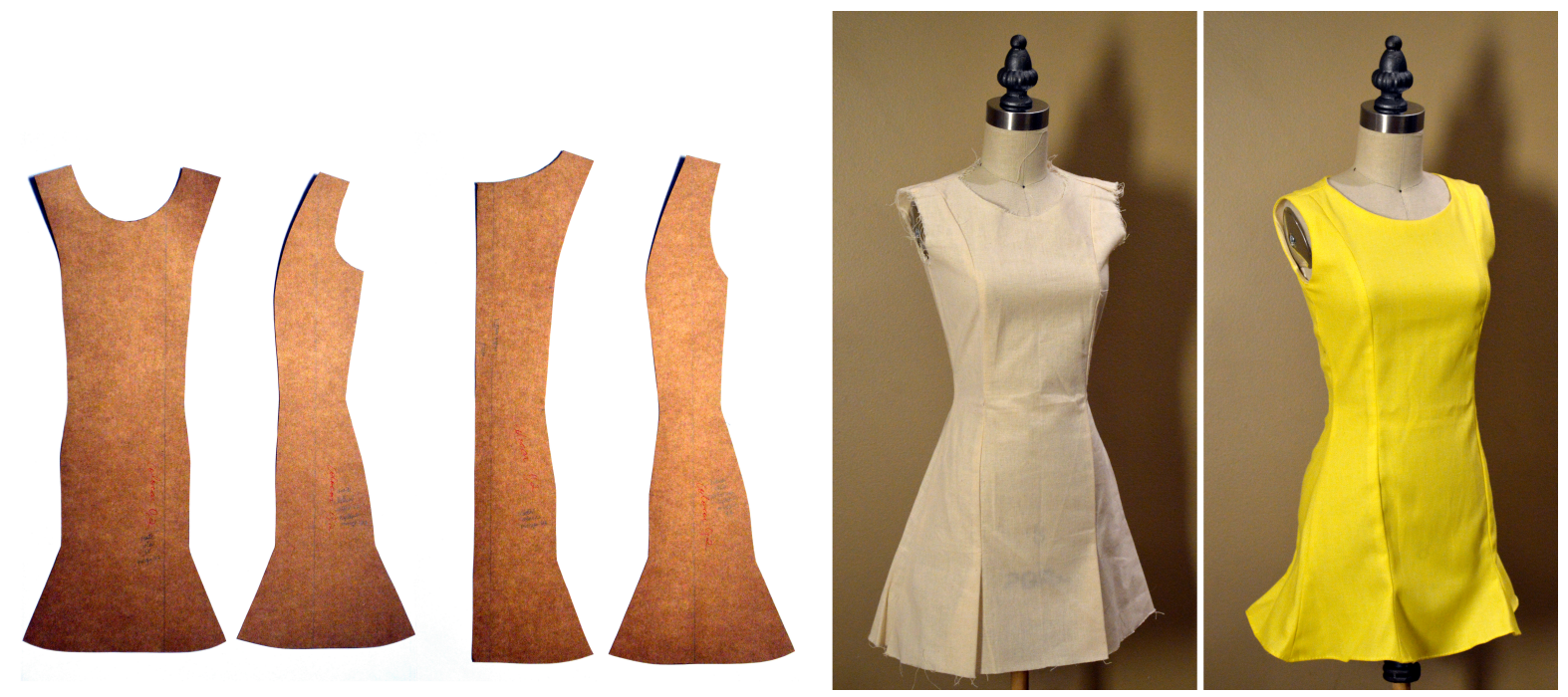

Figura 10 - Conjunto de modelagem, peça piloto e peça confeccionada. Fonte: autora.

Os protótipos serão armazenados e transportados em uma espécie de guardaroupas portátil com rodas e dispostos em araras com cabides (Figura 9). Suas modelagens são armazenadas em pastas plásticas penduradas no cabide da respectiva peça. Cada modelo será acompanhado por uma ficha técnica com desenho ou ilustração, desenho técnico, desenho esquemático da modelagem e descrição detalhada com o código da peça, tipo, nome técnico e popular, efeitos e acabamentos utilizados, tipo de tecido, grau de dificuldade, dentre outras. Uma planilha servirá de referência para consulta das características das peças quanto ao modelo, efeitos utilizados, detalhes presentes e tipos de acabamento, o que facilita a escolha de acordo com o tema a ser abordado na aula. Por fim, as peças serão etiquetadas com cores e código, de acordo com a classificação do tipo de peça.

\subsection{Organização do recurso pedagógico}

Considerando que o material didático é basicamente um repertório de peças, de efeitos e detalhamentos, criou-se um sistema de organização e catalogação que admite 
distintas formas de agrupamento das peças e diversas abordagens sobre o material. Elas foram classificadas ${ }^{5}$ de acordo com quatro características básicas: modelo, tipos de efeito, tipo de detalhes empregados e acabamentos (Figura 11). Desta forma, além da organização tradicional (saia, blusa, vestido, calça etc.), também é possível montar um conjunto de peças de acordo com seus efeitos utilizados (recortes, volumes, franzidos, pregas, pences), detalhamentos (bolso, manga, gola, decote, fechamento, revel, forro ou cós) ou acabamentos (bainha, viés, aplicações, tipo de costura, tecido, cor e estampas). Isto possibilita que o material se adeque às necessidades de acordo com o andamento do curso.
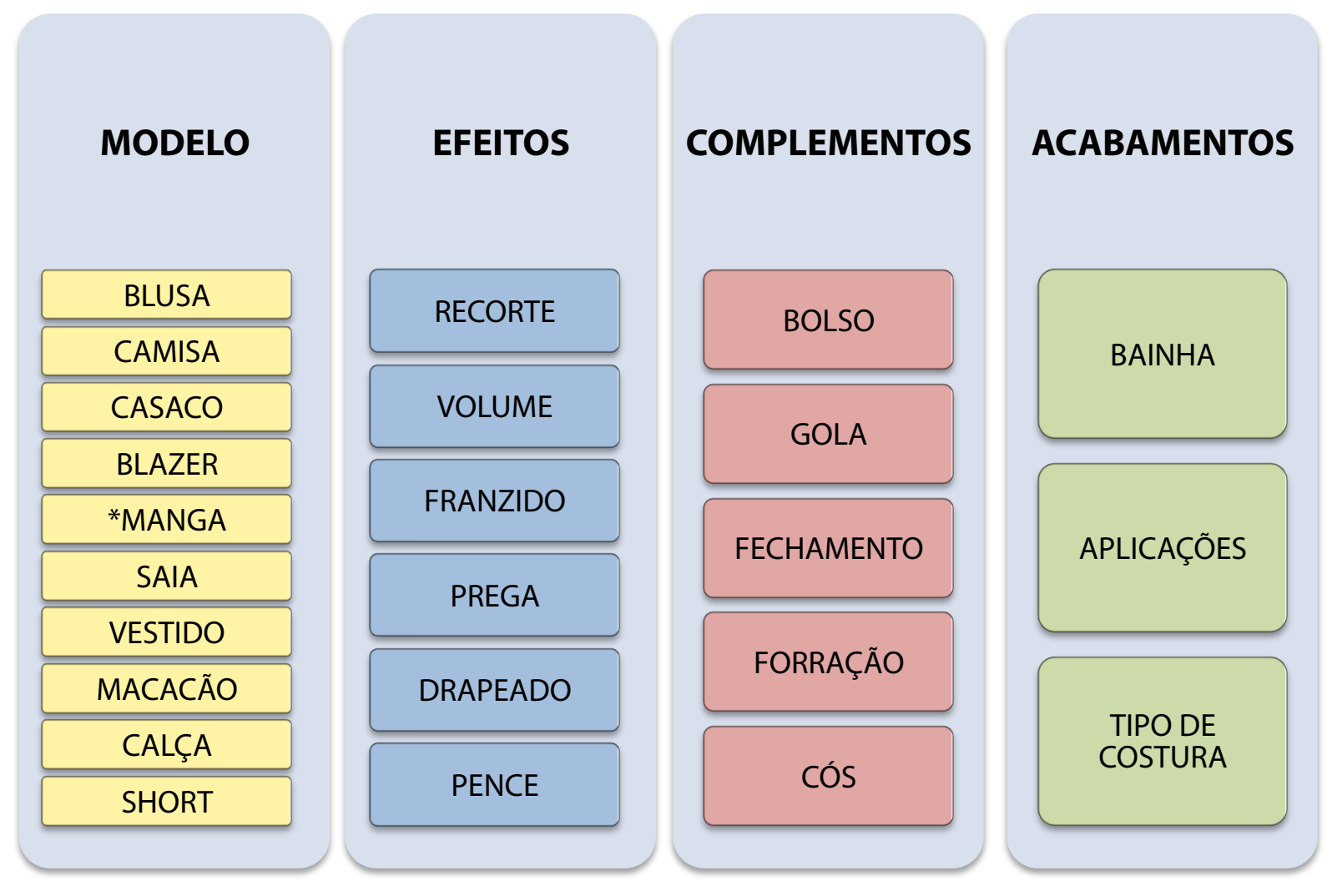

Figura 11 - Subgrupos de classificação dos modelos em meia escala. Fonte: autora.

No caso das peças serem agrupadas por seu modelo, abre-se espaço para que se possa tratar das especificidades de cada tipo. Ao se escolher um conjunto de saias para ser utilizado em sala como repertório, é possível tratar das questões básicas e dos desafios da modelagem desta peça com toda a turma por meio de uma exposição oral ou aula teórica. Na sequência, os alunos podem escolher os efeitos, detalhes e acabamentos de sua peça, de acordo com seus conhecimentos prévios e disposição ao desafio.

\footnotetext{
${ }^{5}$ Para uma classificação mais detalhada, ver Apêndice B - Tabela de classificação dos modelos , p.74.
} 
Por outro lado, se o objetivo for ensinar um efeito específico, é possível montar um conjunto com modelos distintos (saias, blusas, casacos, vestidos e camisas), todos eles com o mesmo efeito. Desta forma, é possível perceber o resultado de uma mesma operação aplicada em diversas situações. No caso de surgir a necessidade de se esclarecer uma dúvida relacionada a algum detalhe, como bolso, gola ou a até acabamentos, também é possível pré-selecionar as peças que possuam esses pormenores.
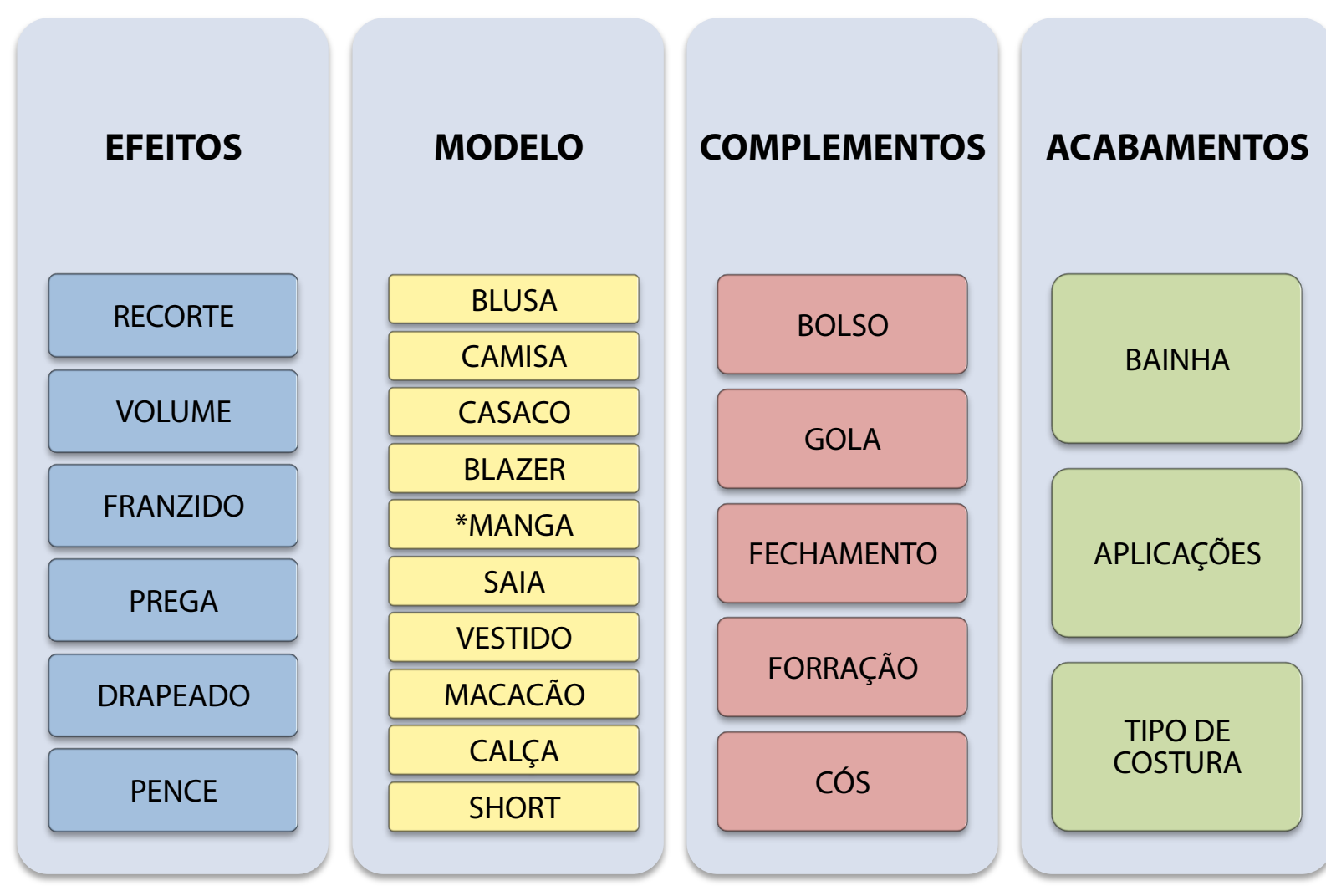

Figura 12 - Classificação alternativa de Subgrupos dos modelos em meia escala. Fonte: autora

A Figura 12 mostra uma forma alternativa de se pensar a organização das peças e do próprio modo de se ensinar modelagem. Neste caso, a seleção inicia-se a partir dos efeitos desejados. Os modelos são então selecionados de acordo com estes critérios préestabelecidos. Esta organização, além de servir como fonte alternativa de consulta ao recurso pedagógico, também pode ser uma forma de estruturar o conhecimento teórico de modelagem, que basicamente consiste em aplicar efeitos (operações de transformação) sobre moldes básicos (saia, blusa, short, etc.) e seus complementos (bolsos, golas, mangas) e especificar seus acabamentos. Desta forma, não se aprende a fazer "uma saia com volume", mas se aprende os efeitos de uma operação de acrescentar volume aplicado no caso 
específico de uma saia. Esta mesma operação poderia ser transposta para outros modelos (camisas, vestidos e calças) e seus complementos (fechamentos, bolsos, mangas, etc.).

\subsection{Aplicação e utilização do mostruário tridimensional}

O recurso pedagógico aqui apresentado é considerado uma ferramenta aberta para mediar os processos de ensino-aprendizagem de modelagem. Como esses processos são complexos e variados, sua aplicação deve comportar uma diversidade de situações de aprendizagem.

A opção em não se criar uma metodologia rígida é deliberada, pois acredita-se que deve haver espaço para as descobertas durante o próprio contato com o material. Desta forma, ao se incentivar uma postura ativa, também se valoriza a construção do conhecimento pelo próprio educando. Ou seja, é ele quem por meio do manuseio, da investigação e da vontade própria, descobre e conquista para si os saberes compartilhados pelos demais profissionais de modelagem.

Esta abertura é ainda mais relevante quando consideramos que este recurso poderá ser utilizado por outros educadores, cada um com sua própria experiência, sensibilidade e conhecimentos. Também espera-se que estes, ao entrar em contato com o conjunto da obra, descubram as potencialidades e sejam estimulados a desenvolver suas próprias práticas pedagógicas. Não temos aqui a pretensão de dar uma resolução para o problema do ensino de modelagem, mas apenas uma contribuição para permitir e estimular seu livre exercício em um cenário complexo e plural.

A seguir, apresentamos uma proposta de uso do material pedagógico. Não se espera aqui prescrever uma único maneira de seu emprego, mas apenas indicar um possível caminho que responda adequadamente a um contexto didático dinâmico.

Sua utilização é bastante simples, já que as peças foram feitas e organizadas para estarem disponíveis para consulta e investigação. Elas foram classificadas de acordo com diversos critérios, características, materiais, acabamentos, nível de dificuldade, dentre outros, e poderão ser reordenadas e reagrupadas de inúmeras maneiras. Basta que o professor faça uma pré-seleção das peças, de acordo com o conteúdo ou assunto a ser abordado em aula. O conjunto pode servir como suporte para uma exposição oral sobre o assunto e também como fonte de consulta para os trabalhos individuais. Cada roupa em meia escala será acompanhada de sua peça piloto em algodão cru, sua modelagem definitiva e ficha 
técnica. O restante do conjunto também pode ficar disponível para consulta no caso de surgirem dúvidas sobre questões não abarcadas pela pré-seleção ou no caso de demandas específicas de alunos.

O formato da aula deve priorizar o espírito de descoberta e de investigação. Devese estimular o livre manuseio e permitir que o material seja levado para as mesas de trabaIho para ser utilizado como repertório de modelagens, efeitos e acabamentos. Espera-se que sirva como fonte de inspiração e referência para os trabalhos individuais e ponte de conexão entre a modelagem bidimensional e a roupa finalizada. Afinal, possibilitar que os alunos tenham a liberdade de alterar e desenvolver seus modelos é colocá-los numa posição de controle também sobre o sua própria aprendizagem. Esse protagonismo é importante para guiar e dar vigor ao processo cognitivo.

Quanto à postura do professor, propomos que este busque fazer com que suas práticas pedagógicas sejam voltadas para capacitar o aluno para o ofício de modelagem em sua condição real - com seus imprevistos, diversidade de possibilidades de soluções, constante necessidade de mediação e situações únicas. Isto implica em criar situações de aprendizagem nas quais as possibilidades de soluções sejam igualmente variadas e mediadas; as dúvidas sejam ponto de partida para as descobertas; as situações de risco sejam enfrentadas tanto pelos alunos quanto pelo professor; e o conhecimento seja desvendado pelo próprio fazer.

Apesar de ter sido criado a partir de uma conjuntura específica - ensino técnico de modelagem plana feminina no IFB - acreditamos que sua aplicação abrange outros contextos de aprendizagem. O recurso também pode ser utilizado em diversos níveis de educação, como no ensino superior e também em cursos livres, desde que respeitado seus princípios e pressupostos pedagógicos. Com a ampliação do repertório - que nesta versão inicial possui 80 peças - é possível expandir o escopo para que atenda às demandas específicas de outros cursos. Além disso, por se tratar de um acervo técnico, também é possível que seja utilizado em outras disciplinas do próprio curso, como as de costura, desenho técnico e modelagem tridimensional.

\section{Considerações finais}

O mostruário tridimensional foi desenvolvido para facilitar a comunicação em sala de aula, expandir o repertório, ampliar a habilidade de visualização tridimensional e permi- 
tir aos alunos antever soluções que só seriam visíveis nas etapas subsequentes da produção do vestuário. Além disso, os modelos são um meio alternativo pelo qual os conceitos e conteúdos teóricos são expressados na matéria. Seu formato é um sistema aberto que demanda movimentos/mobilizações autônomas da prática. Ele permite a liberdade e a diversidade de abordagens, já que o professor pode problematizar diversos assuntos de diferentes maneiras e compartilhá-los com os alunos. Sua função, mais do que ensinar um conteúdo, é mediar o processo de ensino-aprendizagem.

A crescente diversidade no contexto da sala de aula e o progressivo aumento do reconhecimento dessas individualidades - em substituição a um aluno padrão - colocam os docentes em uma posição de revisão de suas práticas. Neste sentido, valorizar as dificuldades, aptidões e interesses em sala é reconhecer a condição única de cada aprendiz enquanto aluno real.

Quando confrontamos o processo complexo de interação e de aquisição de conhecimento com a variedade de sujeitos existentes em um mesmo ambiente, inevitavelmente teremos diversos tipos, situações e configurações para serem mediadas. Neste contexto, o papel de um material não se limita a organizar os conteúdos de forma didática, mas de gerenciar essa diversidade de situações de aprendizagem em sala de aula. No fim das contas, trata-se de criar condições mais favoráveis para que a aprendizagem ocorra em um número maior de situações e com um número maior de sujeitos.

Obviamente, este recurso não tem nenhuma pretensão de se tornar uma salvação para a aprendizagem de modelagem, pois este processo sempre apresentará seus desafios, independentemente dos instrumentos adotados. Como qualquer ferramenta, ele permanece estático em sua disponibilidade, aguardando ser conduzido à ação. A utilização dos modelos é um meio de ensino de modelagem, mas também de uma mudança mais abrangente na forma como se constrói o conhecimento. O que se espera deste recurso é que seja um convite àqueles que desejam participar de um processo de descoberta e de transformação.

Por fim, espera-se que este trabalho seja um ponto de partida para o aprofundamento de algumas questões levantadas aqui. As implicações em se considerar o ensino técnico como preparação para o trabalho real - e não apenas para o trabalho prescrito são bastante significativas e indicam um salto qualitativo na compreensão do papel desta modalidade. O reconhecimento da complexidade do ofício de modelagem fortalece sua 
identidade e promove o aperfeiçoamento de suas práticas, recursos pedagógicas e ambiente de ensino. Distinguir sua dinâmica própria - desvinculando-se do ensino superior também abre espaço para que o ensino profissional seja reconhecido em seu alcance e profundidade, indicando uma possível direção para a formação e o aperfeiçoamento dos professores desta modalidade. 


\section{Referências}

BEDUSCHI, Danielle Paganini. Diretrizes para o ensino de modelagem do vestuário. 2013. 202 f. Dissertação (Mestrado em Ciências) - Programa de Pós-Graduação em Têxtil e Moda, Escola de Artes, Ciências e Humanidades, Universidade de São Paulo, São Paulo, 2013.

BEDUSCHI, Danielle Paganini; ITALIANO, Isabel Cristina. Descrição e análise da evolução dos métodos e obras de modelagem plana no Brasil: de 1960 aos dias atuais. REDIGE v. 4, n. 02, ago. 2013.

CUNHA, Daisy Moreira. Problemas de trabalho e questões de linguagem. Educação e Realidade, v. 35, n.1, p.49-64, 2010.

CUNHA, Maria Isabel da. O professor universitário na transição de paradigmas. Araraquara: JM Editora, 1998.

DUARTE, Rosário. Entrevistas em pesquisas qualitativas. Educar, Curitiba, n.24, p.213225,2004

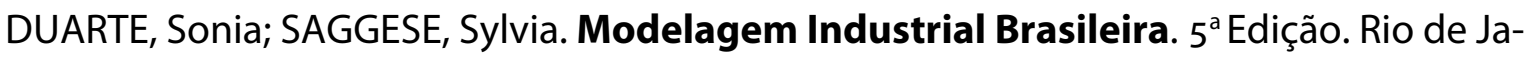
neiro: Sonia Duarte e Sylvia Saggese, 2010.

FULCO, Paulo; SILVA, Rosa Lúcia de Almeida. Modelagem Plana Feminina. Rio de janeiro: Ed. Senac Nacional, 2008.

HEINRICH, Daiane Pletsch. Modelagem e técnicas de interpretação para confecção industrial. Novo Hamburgo: Feevale, 2005.

ILLERIS, Knud. Learning and non-learning in school and beyond. New York: Routledge, 2007 [1999].

Towards a contemporary and a comprehensive theory of learning. Internacional Journal of Lifelong Education, vol. 22, no. 4 (july-august 2003), 396-406.

(org.). Teorias Contemporâneas da Aprendizagem. Porto Alegre: Penso, 2013.

INSTITUTO FEDERAL DE BRASÍLIA. Proposta de curso de educação profissional - técnico de nível médio subsequente em vestuário. IFB Campus de Taguatinga. Brasília, 2011.

KEGAN, Robert. Que "forma" transforma? Uma abordagem construtivo-evolutiva à aprendizagem transformadora. In: Teorias Contemporâneas de Aprendizagem. Porto Alegre: Penso, 2013.

KENNER, Roberto Ranna. A qualidade de quem nos veste: um estudo sobre a contribuição de indústrias e escolas para a formação profissional do setor da confecção do vestuário no paraná. Curitiba, 2005. Dissertação de mestrado. 
KUENZER, Acacia Zeneida. Competência como práxis: os dilemas da relação entre teoria e prática na educação dos trabalhadores. Rio de Janeiro: Boletim Técnico do Senac, Vol. 28, 2002.

LEITE, Adriana Sampaio. Uma reflexão sobre o material didático para o ensino de técnicas de modelagem. VI Colóquio de Moda. São Paulo, 2010.

LUCKESI, Cipriano Carlos. Filosofia da Educação. São Paulo, Cortez, 1994.

MENEZES, Marizilda dos Santos; SPAINE, Patrícia Aparecida de Almeida. Modelagem plana industrial do vestuário: diretrizes para a indústria do vestuário e o ensinoaprendizado. Projética, Londrina, v.1, n.1, p. 82-100, dez 2010.

MINAYO, Maria Cecília de Souza (org.). Pesquisa Social: teoria, método e criatividade. Petropólis: Vozes, 2004.

MINAYO, Maria Cecília de Souza. Análise qualitativa: teoria, passos e fidedignidade. Ciência \& Saúde Coletiva, 17(3:p.621-626), Rio de Janeiro, 2012

MITJÁN MARTINEZ, Albertina. A teoria da subjetividade de González-Rey: uma expressão do paradigma da complexidade na psicologia in GONZÁLEZ-REY, Fernando. Subjetividade, complexidade e pesquisa em psicologia. São Paulo: Pioneira Thomson Learning, 2005.

Criatividade no trabalho pedagógico e criatividade na aprendizagem in Tacca, Maria Carmen V. R. (org.). Aprendizagem e Trabalho Pedagógico. São Paulo: Alínea, 2008.

Criatividade, personalidade e educação. São Paulo: Papirus, 1997.

PALLASMAA, Juhani. The thinking hand: existential and embodied wisdom in arthitecture. Chichester: Wiley, 2009.

PESSOA, Rosane Rocha. O livro didático na perspectiva da formação de professores. Trab. Ling. Aplic., Campinas, 48 (1) 53-69, Jan/Jun 2009.

ROSA, Stefania. Alfaiataria: modelagem plana masculina. Brasília: SENAC-DF 2008.

SABRÁ, Flávio. Modelagem: tecnologia em produção de vestuário. Rio de Janeiro: SENAI-CETIQT, 2009.

SOUZA, Sidney Cunha de. Introdução à tecnologia da modelagem industrial. Rio de Janeiro: SENAI-CETIQT, 1997.

TRINQUET, Pierre. Trabalho e educação: 0 método ergológico. HISTEDBR On-Line, v. número especial, p. 93-113, 2010. 


\title{
Apêndice A - Questionário do workshop de modelagem
}

\author{
Questionário - workshop "Interpretação de saias"
}

1. Você possui experiência na área de produção do vestuário? (mais de uma resposta permitida)
a. Costura
b. Modelagem
c. Nenhuma

2. Quais são as principais dificuldades ao se fazer modelagem? (mais de uma resposta permitida)
a. Pensar nos acabamentos que só serão realizados na costura
b. Imaginar as partes que se encaixam
c. Transformar a base no modelo desejado sem nenhuma referencia
d. Matemática
e. Geometria

3. A aprendizagem de modelagem plana possui dificuldades com relação à visualização tridimensional do produto final?
a. Sim
b. Não

4. Você avalia que o protótipo tridimensional da modelagem facilitou o aprendizado?
a. Sim
b. Não

5. Durante o módulo "interpretação de saias" qual foi a relevância/impacto sobre a sua compreensão da modelagem na utilização do protótipo confeccionado?
a. pouca relevância
b. média relevância
c. muita relevância

6. De que maneira você utilizou o protótipo ?
a. Apenas observou a demonstração da professora
b. Consultou a modelagem e o protótipo durante a aula

7. Se você consultou a modelagem e o protótipo durante a aula, foi com qual finalidade? (mais de uma resposta permitida)
a. recordar as explicações da professora
b. usar como base para seu exercício
c. conhecer os acabamentos e estrutura interna
d. utilizou para mostrar/discutir e esclarecer com colegas/professora algo que não estava conseguindo explicar verbalmente
e. outra: 
8. Você acha que o protótipo melhorou seu modo de fazer modelagem quando comparado à modelagem feita no dia anterior?
a. Sim
b. Não

9. Se sim, de que maneira? (mais de uma resposta permitida)
a. Me proporcionou mais confiança no processo de modelagem
b. Facilitou a visualização tridimensional da peça
c. Dinamizou a comunicação em sala para exemplificar/tirar dúvidas do exercí- cio entre as colegas e professor
d. Permitiu maior clareza sobre o processo e o produto que está sendo feito
e. Deu motivação, estimulou a criatividade, inspiração para desenvolver mol- des




\section{Apêndice B - Tabela de classificação dos modelos}

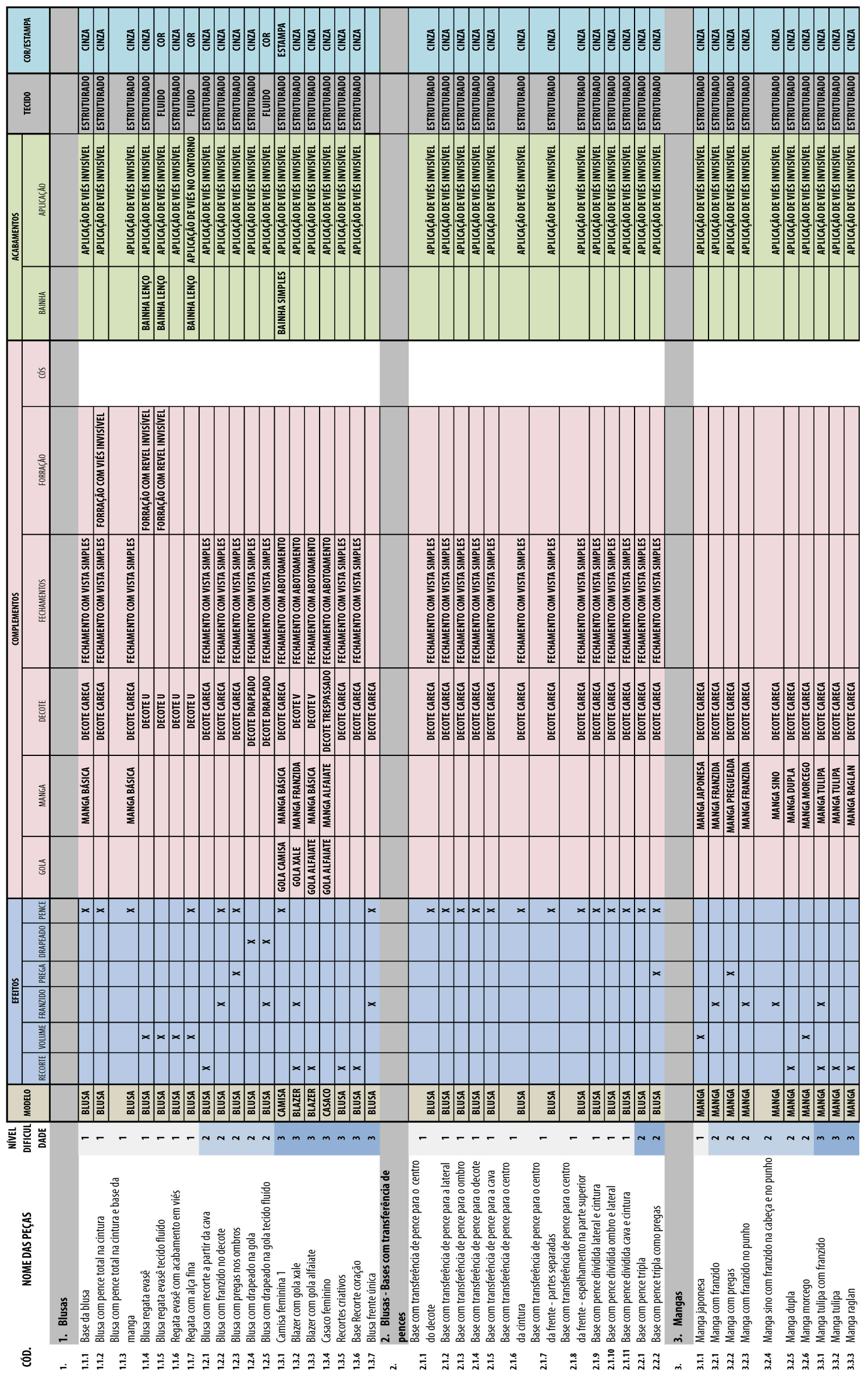




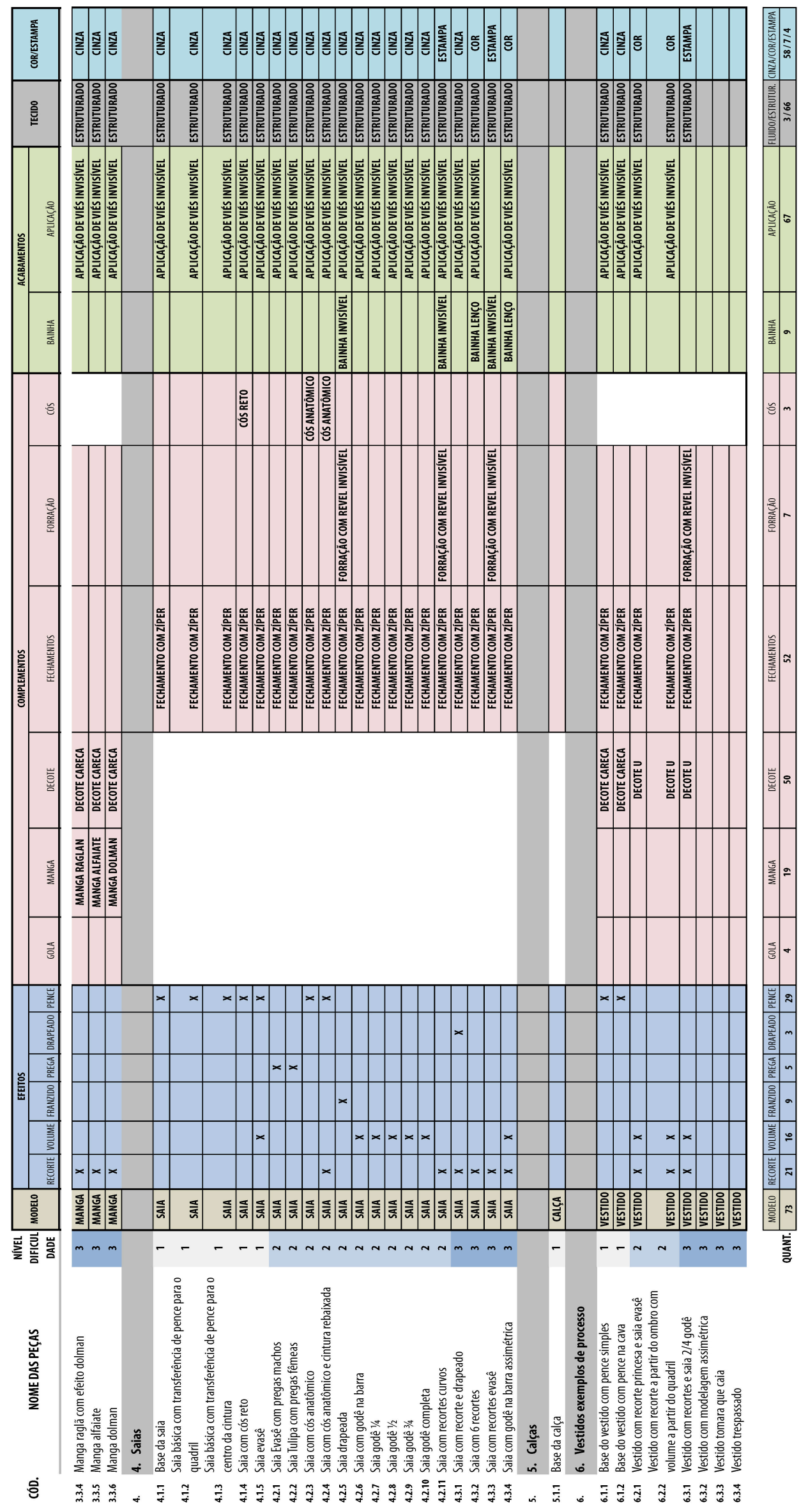




\section{Apêndice C - Gráficos de frequência de ocorrência de peças}
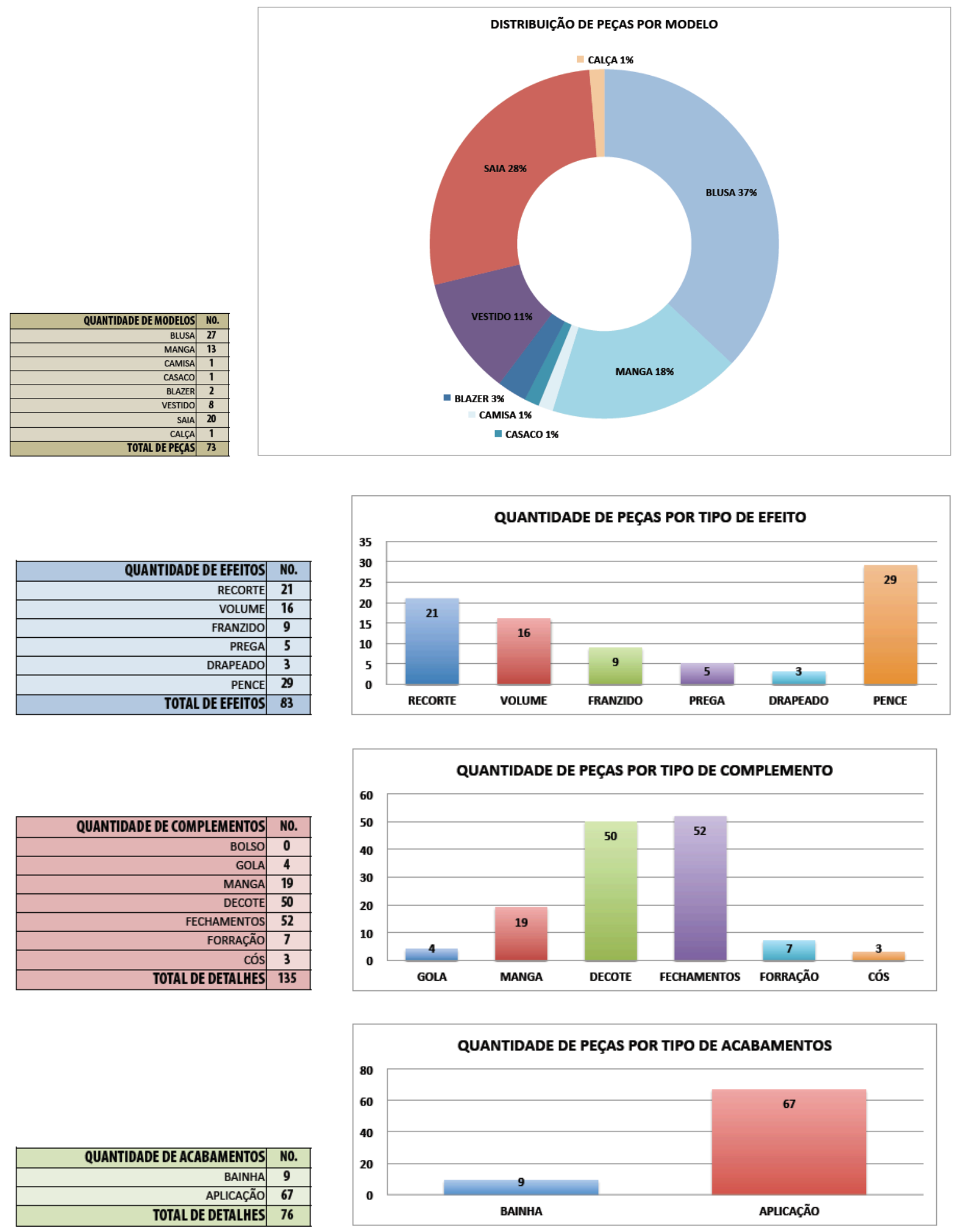


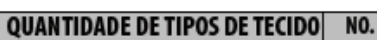
FLUIDO 3 \begin{tabular}{r|c}
\hline ESTRUTURADO & 66 \\
\hline
\end{tabular} TOTAL DE DETALHES 69

\begin{tabular}{|c|c|}
\hline $\begin{array}{r}\text { QUANTIDADE DETECIDOS COM COR/ } \\
\text { ESTAMPA }\end{array}$ & No. \\
\hline CINZA & 58 \\
\hline COR & 7 \\
\hline ESTAMPA & 4 \\
\hline ESTAMPA FIXA & 0 \\
\hline TOTAL DE DETALHES & 69 \\
\hline
\end{tabular}

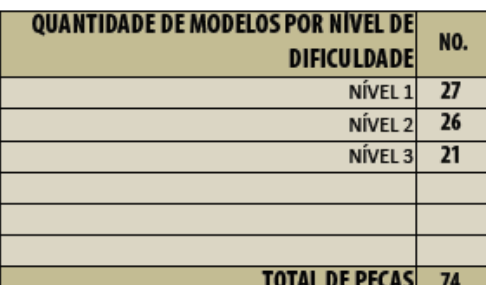

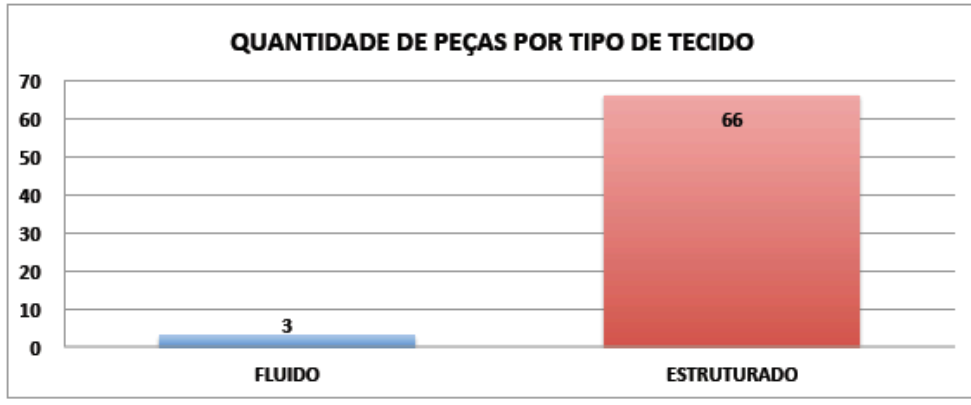

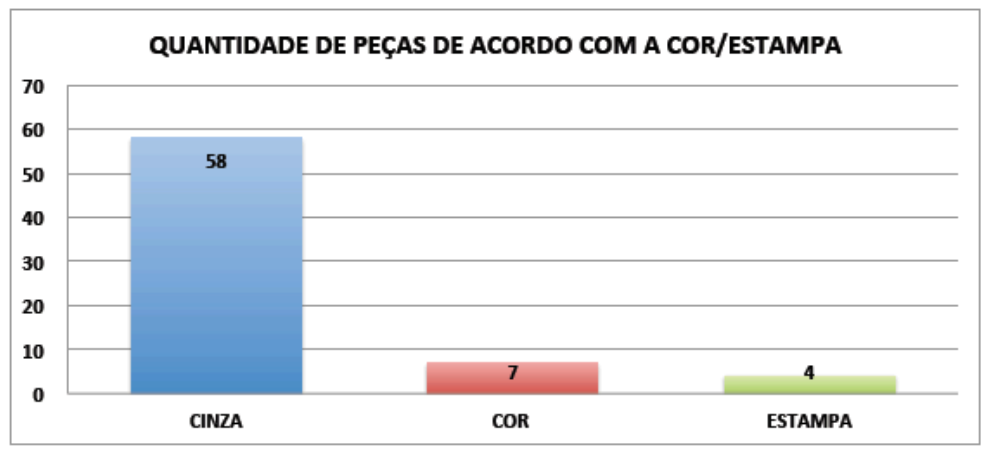

QUANTIDADE DE MODELOS POR NÍVEL DE DIFICULDADE

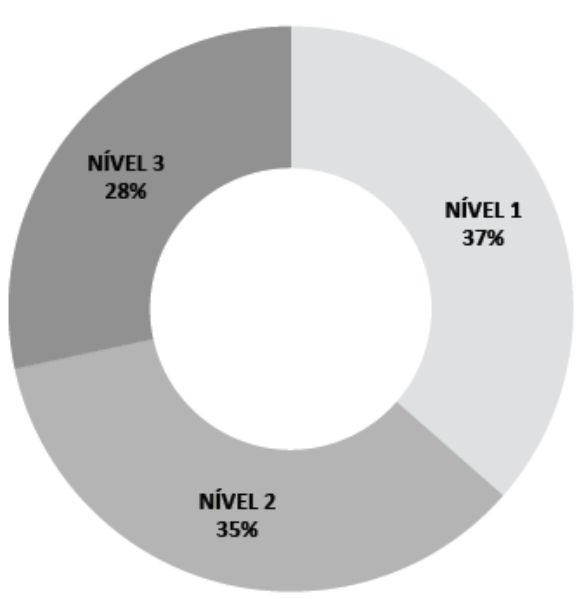



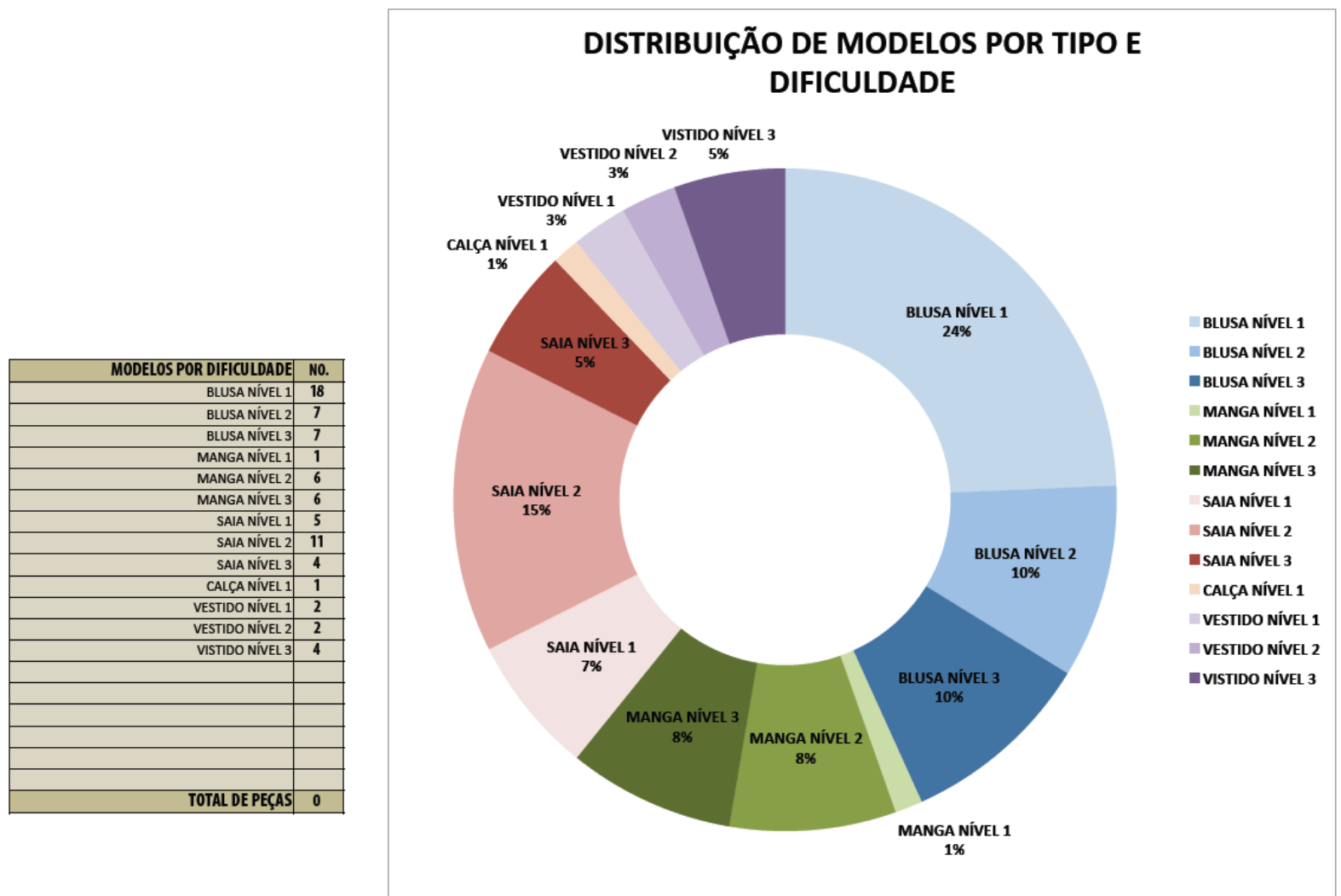


\section{Anexo A - Matriz curricular do curso Técnico em Vestuário do Instituto Federal de Brasília}

\begin{tabular}{|c|c|c|c|}
\hline \multicolumn{4}{|l|}{ Módulo I - Formação Básica } \\
\hline Componente Curricular & \begin{tabular}{|c|}
$\mathrm{CH}$ \\
$\begin{array}{c}\text { Semestral } \\
\text { h/a }\end{array}$ \\
\end{tabular} & $\begin{array}{c}\mathrm{CH} \\
\begin{array}{c}\text { Semestral } \\
\mathbf{h}\end{array} \\
\end{array}$ & $\begin{array}{l}N^{0} \text { Aula } \\
\text { Semana }\end{array}$ \\
\hline Desenho do vestuário & 60 & 50 & 3 \\
\hline Modelagem Feminina & 90 & 75 & 5 \\
\hline Materiais têxteis e produtos & 90 & 75 & 5 \\
\hline Tecnologia da confecção & 60 & 50 & 3 \\
\hline História do vestuário & 60 & 50 & 3 \\
\hline Comunicação Técnica & 48 & 40 & 2 \\
\hline Introdução à Informática & 36 & 30 & 2 \\
\hline Qualidade de Vida no Trabalho & 36 & 30 & 2 \\
\hline TOTAL & 480 & 400 & 25 \\
\hline
\end{tabular}

\begin{tabular}{|c|c|c|c|}
\hline \multicolumn{4}{|c|}{ Módulo II - Auxiliar de Costura (CBO 7632 -10) } \\
\hline Componente Curricular & $\begin{array}{c}\mathrm{CH} \\
\text { Semestral } \\
\text { h/a }\end{array}$ & $\begin{array}{c}\mathrm{CH} \\
\text { Semestral } \\
\mathbf{h}\end{array}$ & $\begin{array}{l}N^{0} \text { Aula } \\
\text { Semana }\end{array}$ \\
\hline Modelagem masculina e infantil & 60 & 50 & 3 \\
\hline Costura: tempos e métodos & 96 & 80 & 5 \\
\hline Laboratório de criatividade tridimensional & 96 & 80 & 5 \\
\hline Segurança no trabalho & 36 & 30 & 2 \\
\hline Desenho técnico do vestuário & 60 & 50 & 3 \\
\hline Informática aplicada ao vestuário & 48 & 40 & 3 \\
\hline Empreendedorismo & 36 & 30 & 2 \\
\hline Inglês Técnico & 48 & 40 & 2 \\
\hline TOTAL & 480 & 400 & 25 \\
\hline
\end{tabular}

\begin{tabular}{|c|c|c|c|}
\hline \multicolumn{4}{|c|}{ Módulo III - Supervisor na Confeç̧ào do Vestuário (CBO 7603) } \\
\hline Componente Curricular & $\begin{array}{c}\mathrm{CH} \\
\text { Semestral } \\
\mathrm{h} / \mathrm{a}\end{array}$ & $\begin{array}{c}\mathrm{CH} \\
\text { Semestral } \\
h\end{array}$ & $\begin{array}{l}N^{9} \text { Aula } \\
\text { Semana }\end{array}$ \\
\hline Modelagem Computadorizada & 60 & 50 & 3 \\
\hline Modelagem tridimensional & 96 & 80 & 5 \\
\hline Costura Industrial & 96 & 80 & 5 \\
\hline Oficina de produçăo de vestuário & 96 & 80 & 5 \\
\hline Processos Têxteis & 60 & 50 & 3 \\
\hline Introduçào a Gestło Ambiental & 36 & 30 & 2 \\
\hline \multirow[t]{2}{*}{ Planejamento e Controle de Qualidade na Produçăo } & 36 & 30 & 2 \\
\hline & 480 & 400 & 25 \\
\hline
\end{tabular}

\begin{tabular}{|r|c|}
\hline Carga Horária Total em hora aula & 1440 \\
\hline Carga Horária Total em hora & 1200 \\
\hline Estagio Curricular Supervisionado (h) & 160 \\
\hline Carga Horária Total do Curso de Tecnico em Vestuário (h) & 1360 \\
\hline
\end{tabular}

